Supporting Information

\title{
Organomagnesium Based Flash Chemistry - Continuous Flow Generation and Utilization of Halomethylmagnesium Intermediates
}

\author{
Timo von Keutz, ${ }^{\mathrm{a}, \mathrm{b}}$ David Cantillo ${ }^{*_{\mathrm{a}, \mathrm{b}}}$ and C. Oliver Kappe ${ }^{*_{\mathrm{a}, \mathrm{b}}}$ \\ ${ }^{\text {a }}$ Institute of Chemistry, University of Graz, Heinrichstrasse 28, 8010, Graz, Austria \\ ${ }^{\mathrm{b}}$ Center for Continuous Flow Synthesis and Processing (CC FLOW), Research Center Pharmaceutical \\ Engineering GmbH (RCPE), Inffeldgasse 13, 8010 Graz, Austria \\ E-mail: david.cantillo@uni-graz.at; oliver.kappe@uni-graz.at
}

\section{Table of Contents}

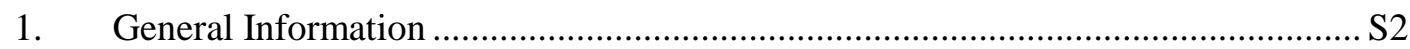

2. Potential side-reactions during the generation of halomethylmagnesium

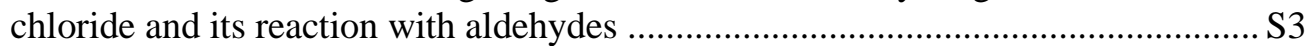

3. Preliminary flow optimization data using a PTFE tubing-based reactor..................S4

4. Characterization of the mixing time in a T-junction and a Plate reactor

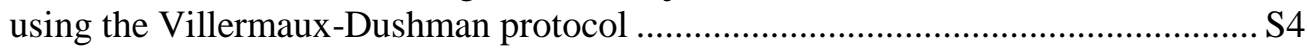

5. Pictures of the flow setup and Table S1 (optimization data)................................... S6

6. General Procedure for the Continuous Flow Synthesis of 1-Aryl

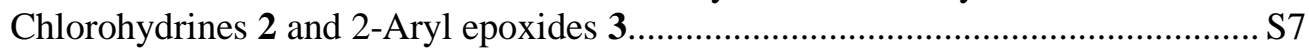

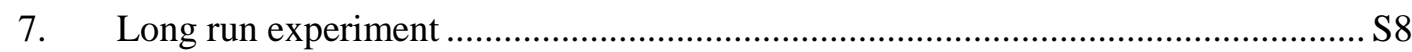

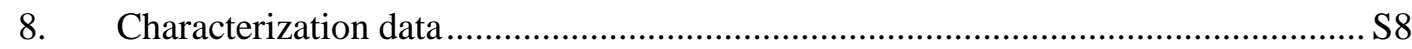

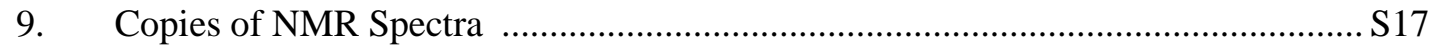

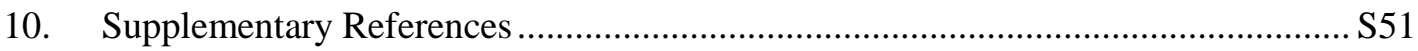




\section{General Information}

${ }^{1} \mathrm{H}$ NMR spectra were recorded on a $300 \mathrm{MHz}$ instrument. ${ }^{13} \mathrm{C}$ NMR and ${ }^{19} \mathrm{~F}$ NMR spectra were recorded on the same instrument at $75 \mathrm{MHz}$ and $282 \mathrm{MHz}$, respectively. Chemical shifts $(\delta)$ are expressed in ppm downfield from TMS as internal standard. The letters s, d, t, q, and m are used to indicate singlet, doublet, triplet, quadruplet, and multiplet, respectively. GC-FID analysis was performed on a Shimadzu GCFID 2030 with a flame ionization detector, using a RTX-5MS column $(30 \mathrm{~m} \times 0.25 \mathrm{~mm}$ ID $\times 0.25 \mu \mathrm{m})$ and helium as carrier gas $\left(40 \mathrm{~cm} / \mathrm{s}\right.$ linear velocity). The injector temperature was set to $280{ }^{\circ} \mathrm{C}$. After $1 \mathrm{~min}$ at $50{ }^{\circ} \mathrm{C}$, the temperature was increased by $25^{\circ} \mathrm{C} \min ^{-1}$ to $300{ }^{\circ} \mathrm{C}$ and kept constant at $300{ }^{\circ} \mathrm{C}$ for $3 \mathrm{~min}$. The detector gases used for flame ionization were hydrogen and synthetic air (5.0 quality). GC-MS spectra were recorded using a Shimadzu GCMS-QP 2010 SE (EI, $70 \mathrm{eV})$. A RTX-5MS column (30 m×0.25 $\mathrm{mm} \times 0.25 \mu \mathrm{m})$ was used, with helium as carrier gas $(40 \mathrm{~cm} / \mathrm{sec}$ linear velocity). The injector temperature was set to $280^{\circ} \mathrm{C}$. After $1 \mathrm{~min}$ at $50^{\circ} \mathrm{C}$, the temperature was increased by $25^{\circ} \mathrm{C} \mathrm{min}^{-1}$ to $300^{\circ} \mathrm{C}$ and kept at $300{ }^{\circ} \mathrm{C}$ for $3 \mathrm{~min}$.. Analytical HPLC analysis was carried out on a C18 reversed-phase (RP) analytical column $(150 \times 4.6 \mathrm{~mm}$, particle size $5 \mathrm{~mm})$ at $37^{\circ} \mathrm{C}$ by using mobile phases A [water/acetonitrile 90:10 $(\mathrm{v} / \mathrm{v})+0.1 \% \mathrm{TFA}]$ and $\mathrm{B}$ (acetonitrile $+0.1 \%$ TFA) at a flow rate of $1.5 \mathrm{~mL} / \mathrm{min}$. The following gradient was applied: linear increase from solution $30 \%$ B to $100 \%$ B in 8 min, hold at 100\% solution B for 2 min. HR-APCI/APPI-MS measurements were performed on a Q-Exactive Hybrid Quadrupole-Orbitrap MS after flow injection on a Dionex Ultimate 3000 series instrument (Thermo Fisher Sci., Erlangen, Germany). The HR-MS was furnished with an atmospheric pressure chemical ionization probe (APCI) and further equipped with an Ion Max UV photo ionisation source using nitrogen as nebulizer and drying gas. Measurements were performed in positive and negative ionisation modes using corona discharge currents of $4 \mu \mathrm{A}$ and $-10 \mu \mathrm{A}$, respectively. Drying gas temperature was $300{ }^{\circ} \mathrm{C}$ and the resolution was set to 70,000 (FWHM). The LC-system was operated in flow injection mode (10 $\mu \mathrm{L}$ injection volume) using acetonitrile containing $0.1 \%$ formic acid $(\mathrm{v} / \mathrm{v})$ as mobile phase with a flow of $0.2 \mathrm{~mL}$ min 1 . Ions were recorded in scan mode within a mass range of $\mathrm{m} / \mathrm{z}$ 150-350. Flash chromatography purifications were carried out on an automated flash chromatography system using cartridges packed with KP-SIL, $60 \AA$ (32-63 $\mu \mathrm{m}$ particle size). All chemicals were obtained from standard commercial vendors and were used without any further purification. 


\section{Potential side-reactions during the generation of halomethylmagnesium chloride and its reaction with aldehydes}

The generation of halomethylmagnesium chloride intermediates and their reaction with electrophiles (in this case aldehydes) can be very challenging, especially when multigram syntheses are attempted or when the temperature is not strictly controlled. Potential side-reactions that could take place during the synthesis are displayed in Figure S1.

Halomethylmagnesium chlorides decompose rapidly. Thus, their generation needs to be very fast. In this context, iodine-containing halomethanes are superior to bromides, as the halogen-magnesium exchange reaction with the Grignard reagent is much faster. Even at relatively low temperatures chloromethylmagnesium chloride can rapidly decompose via two pathways: dimerization of the carbenoid, giving ethene, or nucleophilic addition to another halomethane molecule, which leads to formation of 1,2-dichloroethane. On the other hand, if the turbo Grignard reagent is not fully consumed at the time the aldehyde or ketone is added, it can react with the carbonyl group via a nucleophilc acylic addition. It can also reduce the carbonyl group to the corresponding alcohol. If an acidic proton in $\alpha$-position to the carbonyl is present, the corresponding enolate can be formed leading to an aldol addition.

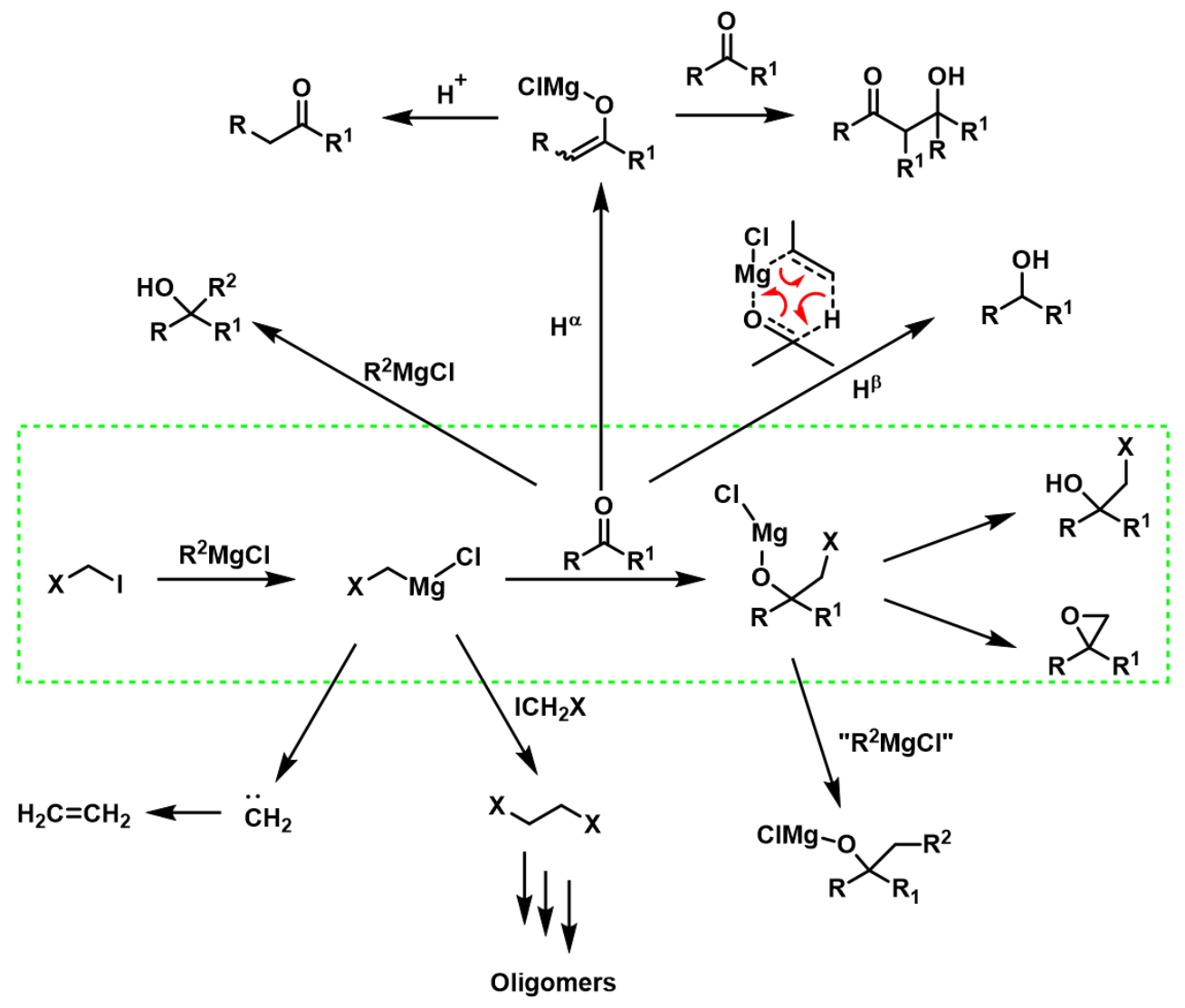

Figure S1. Chart of side-reactions for the generation and utilization of chloromethylmagnesium chloride. 


\section{Preliminary flow optimization data using a PFA tubing-based reactor}

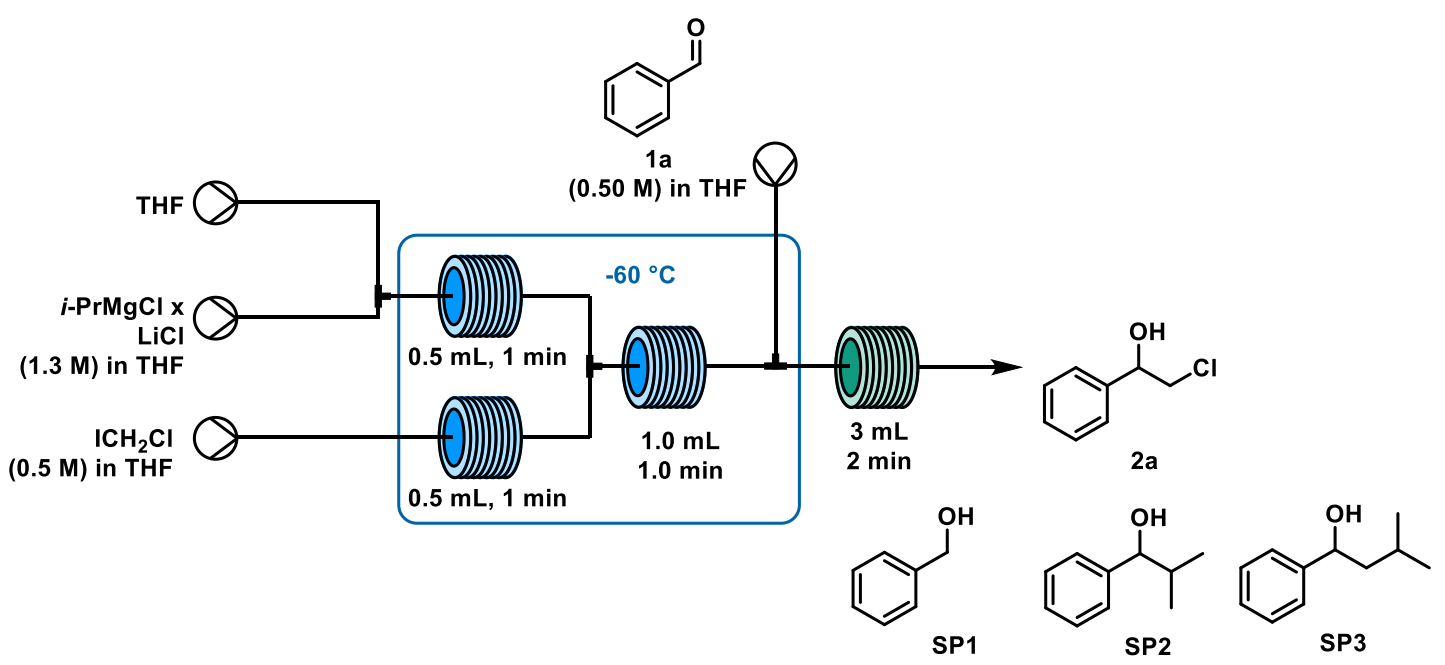

Figure S2. Schematic view of the continuous flow setup utilized for the preliminary optimization in flow
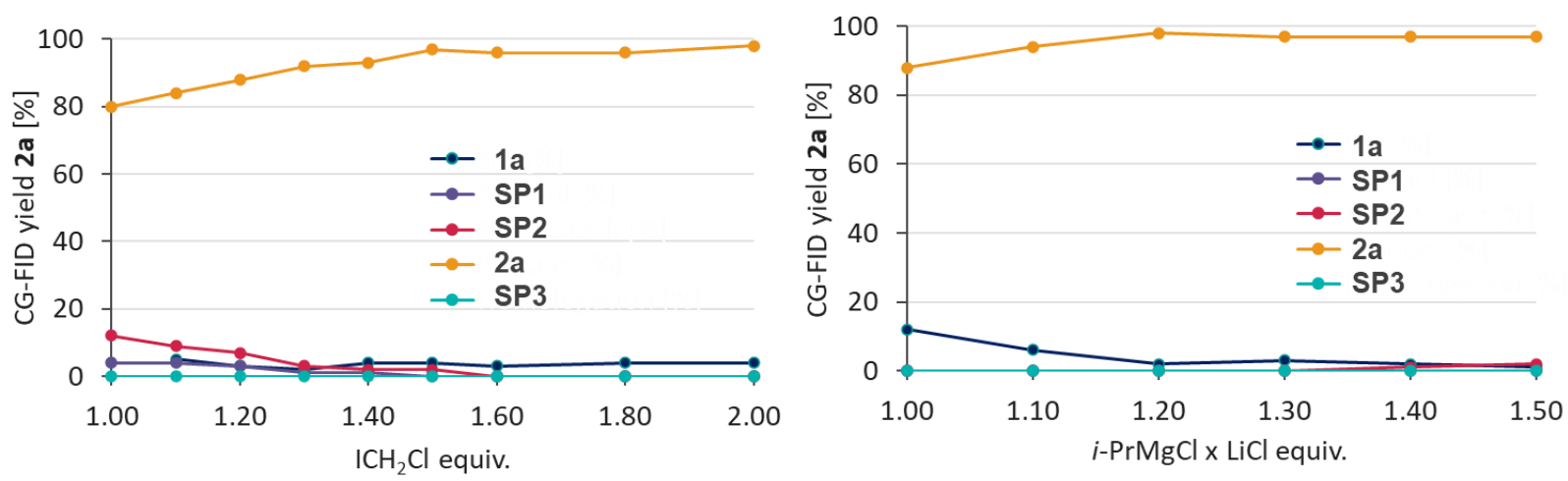

Figure S3. Optimization of the amounts of $\mathrm{CH}_{2} \mathrm{ICl}$ and $i \operatorname{PrMgCl} \cdot \mathrm{LiCl}$

4. Characterization of the mixing time in a T-junction and a Plate reactor using the Villermaux-Dushman protocol

The mixing times of a T-juction (PEEK, $0.5 \mathrm{~mm}$ ID) and the FlowPlate Lab microreactor (LL-mixer, nominal width $0.2 \mathrm{~mm}$, model 1701-4682-HC) were determined using the Villermaux-Dushman protocol. In this experiment two competing reactions take place: a fast acid-base reaction of $\mathrm{NaOH}$ and $\mathrm{HClO}_{4}$ and a slower comproportionation reaction between $\mathrm{KI}$ and $\mathrm{KIO}_{3}$ (Figure $\mathrm{S} 4$ ). ${ }^{\mathrm{S} 1}$

Two stock solutions (A and B) were prepared and pumped using Knauer piston pumps with 20 bar back pressure (Figure S4c). Solution A contained a mixture of $\mathrm{KI}(0.032 \mathrm{M}), \mathrm{KIO}_{3}(0.006 \mathrm{M}), \mathrm{NaOH}_{\text {aq. }}$ $(0.09 \mathrm{M})$ and $\mathrm{B}(\mathrm{OH})_{3}(0.09 \mathrm{M})$ in water. Solution $\mathrm{B}$ contained $\mathrm{HClO}_{4}(0.03 \mathrm{M})$ in water. Using equal flow rates ranging from $0.70 \mathrm{~mL} / \mathrm{min}$ to $5.60 \mathrm{~mL} / \mathrm{min}$, both stream were combined using either the T-connection or the FlowPlate Lab microreactor. The output of the mixer was connected to a residence 
time unit (PFA coil, $0.8 \mathrm{mmID}, 3.0 \mathrm{~mL}$ ). The reaction mixture was monitored inline using an UV-Vis spectrometer (Avantes) attached to a flow-through cell (Ehrfeld, optical path length $3.0 \mathrm{~mm}$ ). Monitoring at $365 \mathrm{~nm}$, corresponding to the amount of $\mathrm{I}_{3}{ }^{-}$generated, permitted the calculation of the mixing time using the equation shown in Figure S4d. Figure S5 shows the results obtained.

(a)

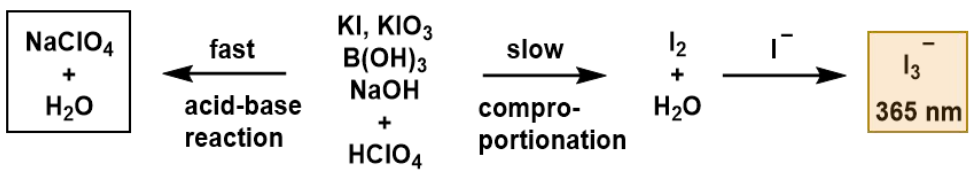

(b)
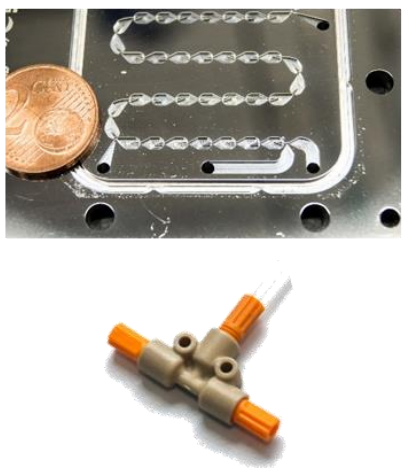

(c)

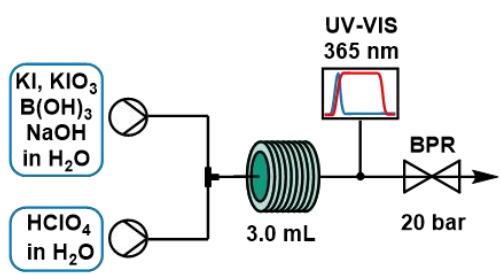

(d) $\mathrm{t}_{m}=0.33(\mathrm{OD})\left[\mathrm{H}^{+}\right]^{-4.55}[\mathrm{KI}]^{-1.5}\left[\mathrm{KIO}_{3}\right]^{5.8}[\mathrm{NaOH}]^{-2}\left[\mathrm{H}_{3} \mathrm{BO}_{3}\right]^{-2}$

Figure S4. (a) Reaction scheme of the two competing reactions. The amount of triiodide formed depends on the mixing efficiency (b) Picture of the FlowPlate and a T-piece made of peek (c) Schematic reaction setup for the Villeraux-Dushman mixing time determination (d) Equation used for the calculation of the mixing time.

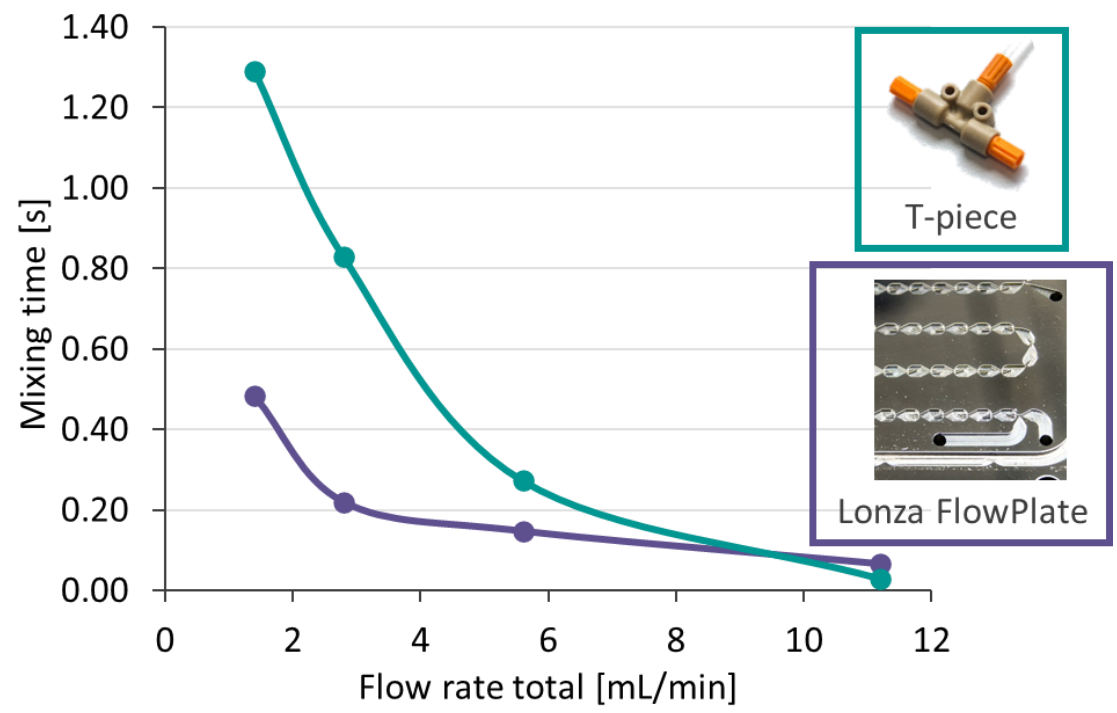

Figure S5. Mixing time determined for a T-junction $(0.5 \mathrm{~mm}$ through hole $)$ and a plate reactor. While at high flow rates the difference is not very significant, at low flow rates $(<4 \mathrm{~mL} / \mathrm{min})$ significant improvement in the mixing efficiency with the plate reactor can be observed. 


\section{Pictures of the Flow Setup}

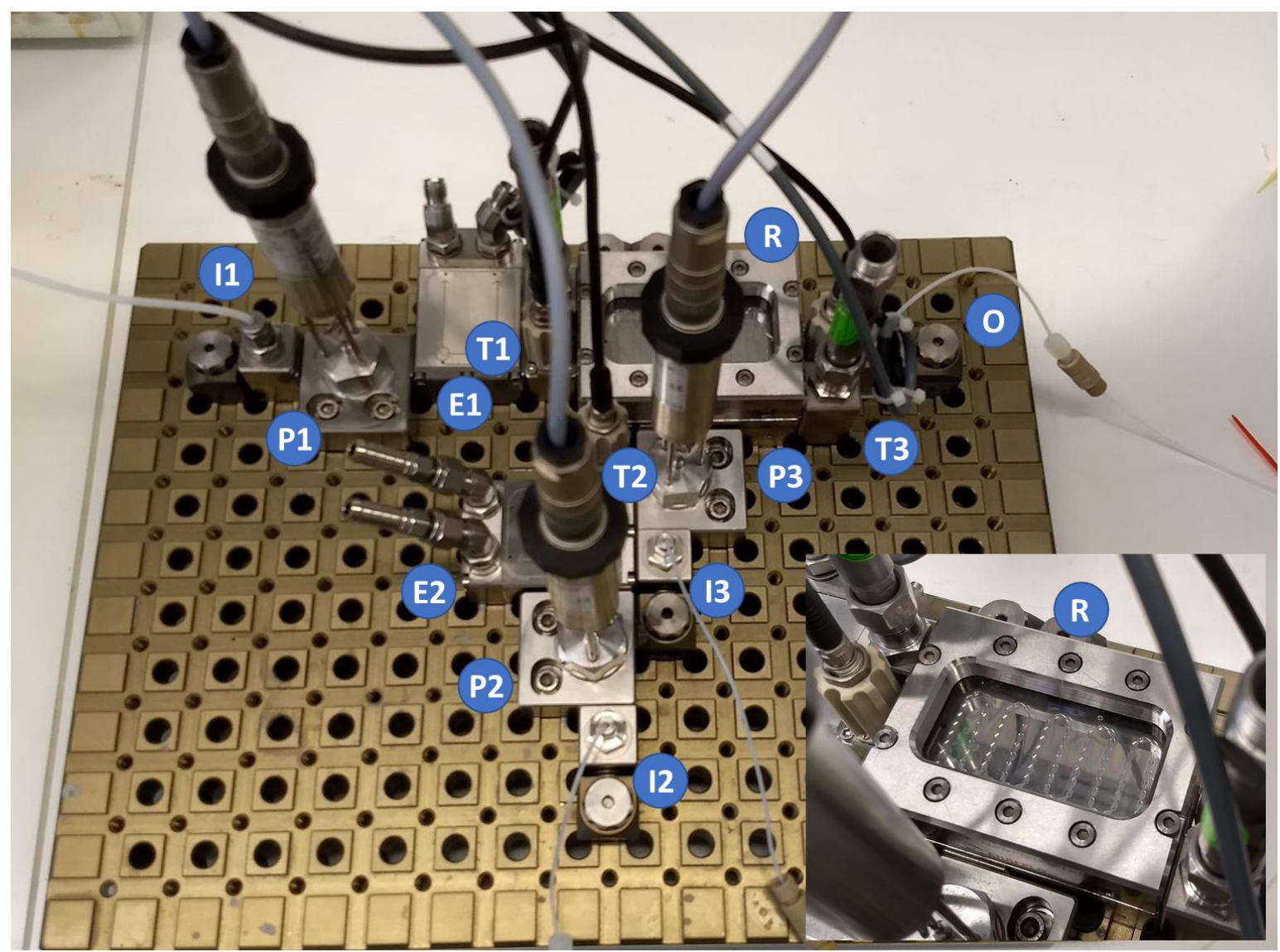

Figure S6. Photograph of the continuous flow setup utilized for the generation and utilization of chloromethylmagnesium chloride. A schematic view of the setup is shown in Figure S7. Tubings for the cooling fluid have been removed for clarity. I1: inlet for the $\mathrm{CH}_{2} \mathrm{ICl}$ solution; I2: inlet for the Grignard reagent solution; I3: inlet for the electrophile solution; E1, E2: heat exchangers (pre-cooling of inlets 1 and 2); P1, P2, P3: pressure sensors; T1, T2, T3: temperature sensors; R: plate reactor (FlowPlate Lab microreactor); O: reactor output.

Table S1. Optimization of the residence time and temperature utilized for the generation of chloromethylmagnesium chloride and its reaction with benzaldehyde (1a). The data is represented as a contour plot in Figure 3B in the manuscript. The flow setup depicted in Figures S6 and S7 was utilized. Values represent the GC-FID yield of product 2a (three samples were collected under steady state operation for each data point; average values are shown).

\begin{tabular}{|cc|cccccc|}
\cline { 3 - 8 } \multicolumn{1}{c|}{} & \multicolumn{7}{c|}{ Temperature $\left({ }^{\circ} \mathbf{C}\right)$} \\
\hline & $\mathbf{0 . 5}$ & 91 & 95 & 96 & 92 & 88 & 71 \\
Residence & $\mathbf{1}$ & 95 & 96 & 97 & 91 & 81 & 71 \\
time (s) & $\mathbf{2}$ & 98 & 98 & 95 & 83 & 72 & 54 \\
& $\mathbf{4}$ & 94 & 86 & 81 & 65 & 57 & 39 \\
& $\mathbf{8}$ & 74 & 72 & 66 & 57 & 37 & 21 \\
\hline
\end{tabular}




\section{General Procedure for the Continuous Flow Synthesis of 1-Aryl Chlorhydrines 2 and 2-Aryl epoxides 3.}

All reactions were performed using the continuous flow setup depicted in Figure S7. A FlowPlate Lab microreactor [LL-mixer, total reaction volume $0.24 \mathrm{~mL}$, nominal width $0.2 \mathrm{~mm}$, model 1701-4682-HC] was utilized as mixing element. All solutions were pumped using HiTec Zang SyrDos syringe pumps. A pre-cooled stream of $i$-PrMgCl$\cdot \mathrm{LiCl}(0.5 \mathrm{M}$ in THF, $2.48 \mathrm{~mL} / \mathrm{min}, 1.20$ equiv.) was combined with a precooled stream of $\mathrm{CH}_{2} \mathrm{ICl}(0.5 \mathrm{M}$ in THF, $3.10 \mathrm{~mL} / \mathrm{min}, 1.50$ equiv.) using injection ports 1 and 2 . The mixture reacted at $-20{ }^{\circ} \mathrm{C}$ for $1.0 \mathrm{~s}(93 \mu \mathrm{L}$ reactor volume). Then, the mixture was combined with a third stream containing a solution of the aldehyde or ketone (0.5 M in THF, $2.07 \mathrm{~mL} / \mathrm{min}, 1.00$ equiv.), which was introduced into the system using an injection loop $(8.0 \mathrm{~mL})$. The second reaction step was completed after a residence time of $1.6 \mathrm{~s}(149 \mu \mathrm{L})$ at $-20^{\circ} \mathrm{C}$. To ensure that the system was operating at steady-state, the reaction output was discarded during $30 \mathrm{~s}$ (15 reactor volumes) before collecting the output solution for $3 \mathrm{~min}(3.1 \mathrm{mmol})$. The crude reaction mixture was quenched at the reactor output with $2 \mathrm{M} \mathrm{NH}_{4} \mathrm{Cl}_{\mathrm{aq}}$. or $1 \mathrm{M} \mathrm{NaOH}_{\text {aq. }}$ to yield the chlorohydrins 2 or the oxiranes $\mathbf{3}$, respectively. The quenched reaction mixture was extracted with $\mathrm{Et}_{2} \mathrm{O}(3 \times 30 \mathrm{~mL})$ and the combined organic layers were washed with brine, dried over $\mathrm{Na}_{2} \mathrm{SO}_{4}$ and the solvents were removed under reduced pressure.

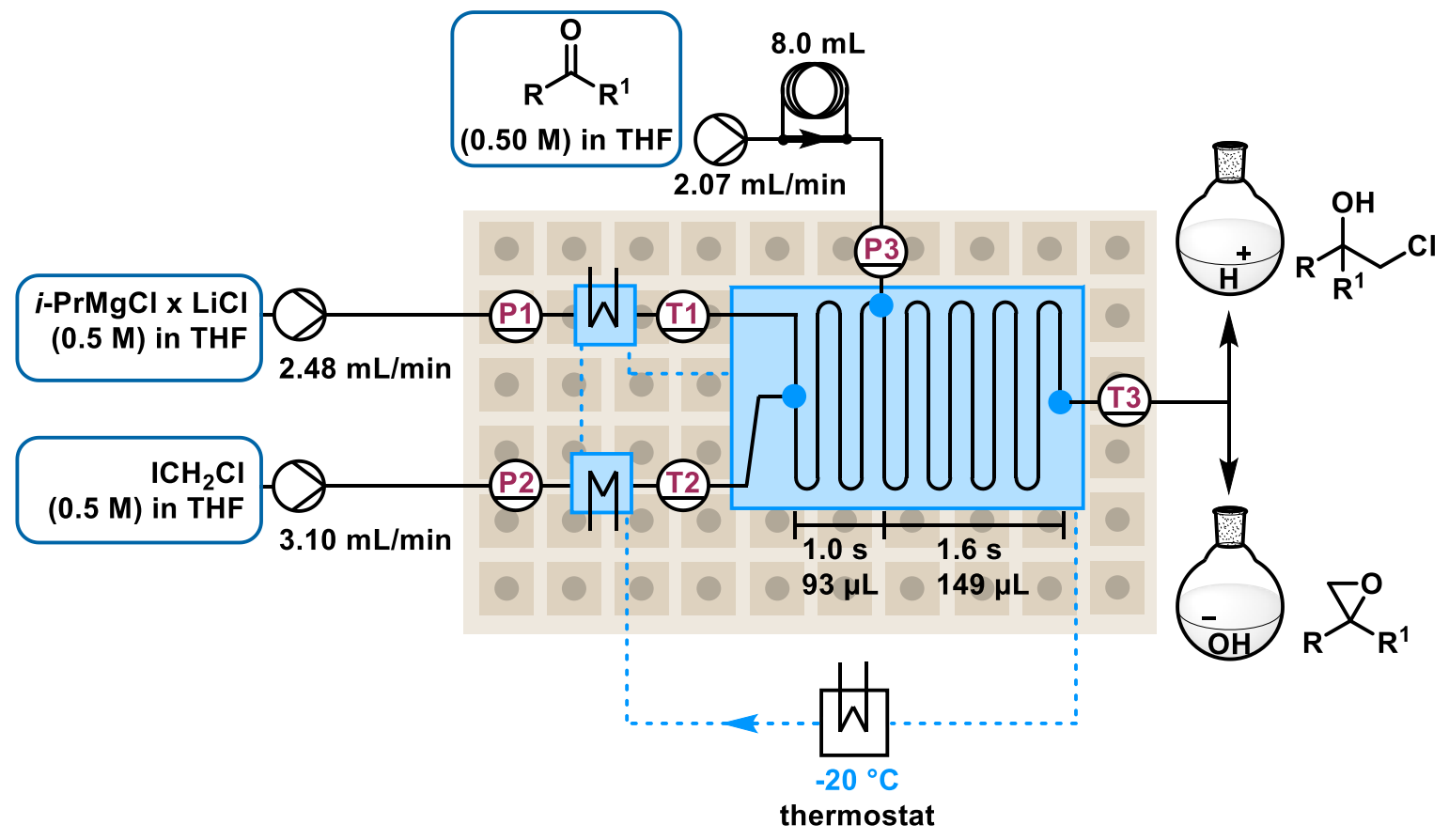

Figure S7. Schematic view of the continuous flow setup used the synthesis of 2-chloroalcohols from corresponding aldehydes and ketones. 


\section{Long run experiment (120 $\mathrm{min}, 124 \mathrm{mmol})$}

To demonstrate the robustness of the reaction setup shown in Figure S7, a scale out experiment was performed using $p$-tolylaldehyde as model substrate. Samples were collected for 5 min each, quenched with $2 \mathrm{M} \mathrm{NH}_{4} \mathrm{Cl}_{\text {aq. }}$ and the organic layer was analysed by GC-FID. In total the long run was performed for 120 min corresponding to over 3800 reactor volumes of starting material solutions. The reaction output showed excellent and stable results over the whole reaction period (Figure S8). All fractions were combined, extracted with $\mathrm{Et}_{2} \mathrm{O}(3 \mathrm{x})$ and the combined organic layers were dried over $\mathrm{Na}_{2} \mathrm{SO}_{4}$. After filtration of the solids, the volatiles were removed under reduced pressure yielding the desired 2-Chloro1-(p-tolyl)ethan-1-ol (2c, $20.3 \mathrm{~g}, 119 \mathrm{mmol}, 96 \%)$ as colorless liquid.

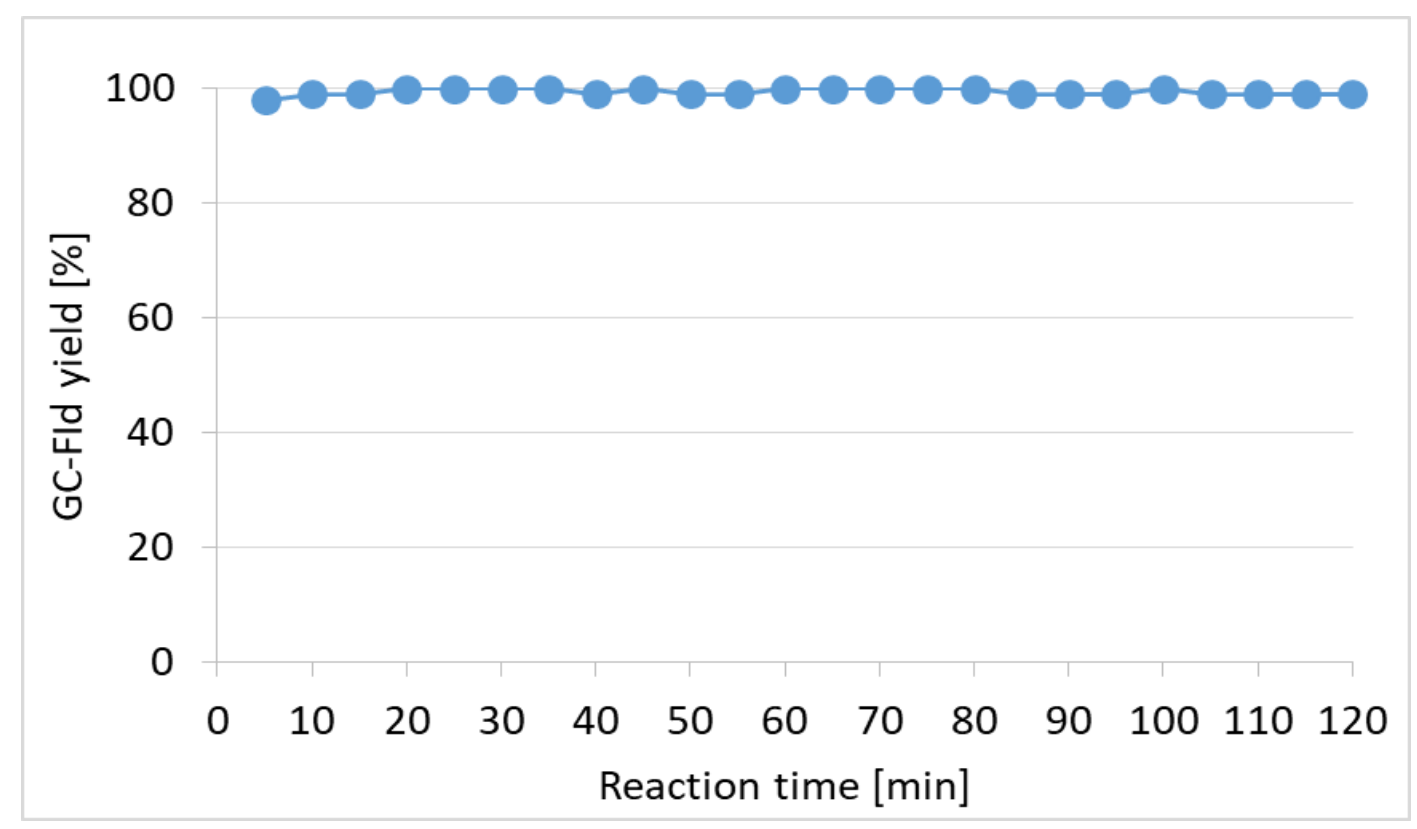

Figure S8. GC-FID monitoring of a $2 \mathrm{~h}$ continuous flow run $(62 \mathrm{mmol} / \mathrm{h}, 124 \mathrm{mmol}$ scale $)$ using the setup depicted in Figure S7.

\section{Characterization data}

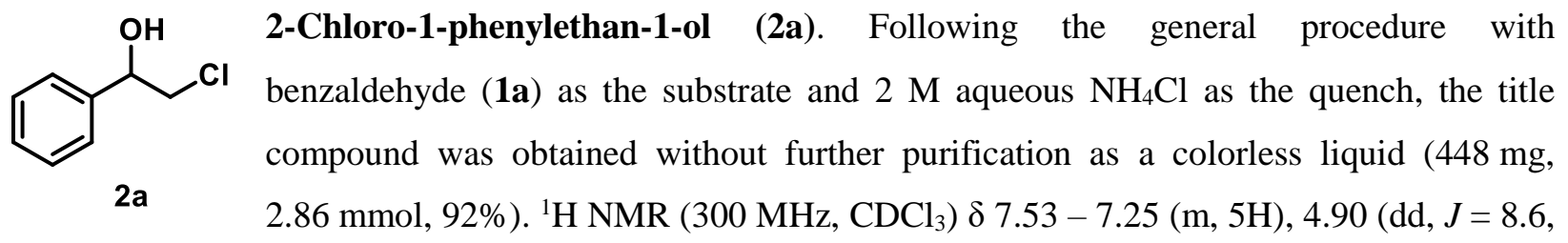
$3.6 \mathrm{~Hz}, 1 \mathrm{H}), 3.82-3.59(\mathrm{~m}, 2 \mathrm{H}), 2.88(\mathrm{~d}, J=5.6 \mathrm{~Hz}, 1 \mathrm{H}) .{ }^{13} \mathrm{C} \mathrm{NMR}\left(75 \mathrm{MHz}, \mathrm{CDCl}_{3}\right) \delta 140.0,128.7$, $128.5,126.1,74.1,50.8$. These data are in agreement with those reported in the literature. ${ }^{\mathrm{S} 2}$ 


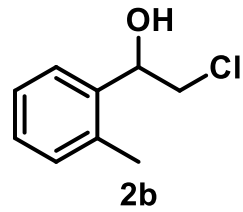

2-Chloro-1-(o-tolyl)ethan-1-ol (2b). Following the general procedure with 2-methylbenzaldehyde (1b) as the substrate and $2 \mathrm{M}$ aqueous $\mathrm{NH}_{4} \mathrm{Cl}$ as the quench, the title compound was obtained without further purification as a colorless liquid (492 mg, $2.88 \mathrm{mmol}, 93 \%) .{ }^{1} \mathrm{H}$ NMR $\left(300 \mathrm{MHz}, \mathrm{CDCl}_{3}\right) \delta 7.58-7.49(\mathrm{~m}, 1 \mathrm{H}), 7.36-7.15(\mathrm{~m}$, $3 \mathrm{H}), 5.13(\mathrm{dd}, J=9.0,3.3 \mathrm{~Hz}, 1 \mathrm{H}), 3.77-3.57(\mathrm{~m}, 2 \mathrm{H}), 2.92(\mathrm{~s}, 1 \mathrm{H}), 2.38(\mathrm{~s}, 3 \mathrm{H}) .{ }^{13} \mathrm{C} \mathrm{NMR}(75 \mathrm{MHz}$, $\left.\mathrm{CDCl}_{3}\right) \delta 138.0,134.8,130.6,128.2,126.5,125.6,70.9,49.9,19.1$. These data are in agreement with those reported in the literature. ${ }^{\mathrm{S} 4}$

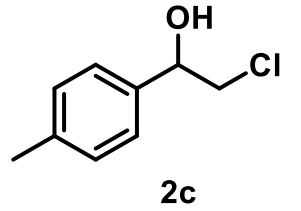

2-Chloro-1-(p-tolyl)ethan-1-ol (2c). Following the general procedure with 4-methylbenzaldehyde (1c) as the substrate and $2 \mathrm{M}$ aqueous $\mathrm{NH}_{4} \mathrm{Cl}$ as the quench, the title compound was obtained without further purification as a colorless liquid (505 $\mathrm{mg}, 2.96 \mathrm{mmol}, 95 \%$ ). A long run experiment was performed over $2 \mathrm{~h}$ under the same conditions to obtain $20.3 \mathrm{~g}(119 \mathrm{mmol}, 96 \%)$ isolated yield. ${ }^{1} \mathrm{H}$ NMR $\left(300 \mathrm{MHz}, \mathrm{CDCl}_{3}\right) \delta 7.34-$ $7.18(\mathrm{~m}, 4 \mathrm{H}), 4.87(\mathrm{dd}, J=8.5,3.8 \mathrm{~Hz}, 1 \mathrm{H}), 3.82-3.59(\mathrm{~m}, 2 \mathrm{H}), 2.89(\mathrm{~s}, 1 \mathrm{H}), 2.40(\mathrm{~s}, 3 \mathrm{H}) .{ }^{13} \mathrm{C} \mathrm{NMR}(75$ $\left.\mathrm{MHz}, \mathrm{CDCl}_{3}\right) \delta 138.3,137.1,129.4,126.1,74.0,50.8,21.2$. These data are in agreement with those reported in the literature. ${ }^{\mathrm{S} 3}$

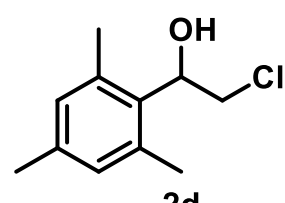

2-Chloro-1-mesitylethan-1-ol (2d). Following the general procedure with 2,4,6trimethylbenzaldehyde (1d) as the substrate and $2 \mathrm{M}$ aqueous $\mathrm{NH}_{4} \mathrm{Cl}$ as the quench, the title compound was obtained without further purification as a yellow oil (588 $\mathrm{mg}$, $2.96 \mathrm{mmol}, 95 \%) .{ }^{1} \mathrm{H} \mathrm{NMR}\left(300 \mathrm{MHz}, \mathrm{CDCl}_{3}\right) \delta 6.86(\mathrm{~s}, 2 \mathrm{H}), 5.30(\mathrm{dd}, J=10.3,3.5$ Hz, 1H), 3.95 (dd, $J=11.3,10.3 \mathrm{~Hz}, 1 \mathrm{H}), 3.64(\mathrm{dd}, J=11.4,3.5 \mathrm{~Hz}, 1 \mathrm{H}), 2.42(\mathrm{~s}, 6 \mathrm{H}), 2.27$ (s, 3H). ${ }^{13} \mathrm{C}$ NMR $\left(75 \mathrm{MHz}, \mathrm{CDCl}_{3}\right) \delta 137.7,136.6,132.1,130.4,72.1,48.1,20.8,20.8$. These data are in agreement with those reported in the literature. ${ }^{\mathrm{S} 2}$

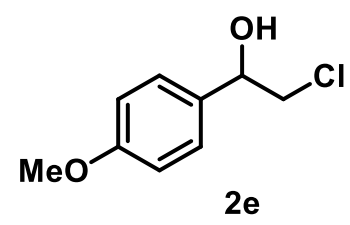

2-Chloro-1-(4-methoxyphenyl)ethan-1-ol (2e). After following the general procedure with 4-methoxylbenzaldehyde (1e) as the substrate and $2 \mathrm{M}$ aqueous $\mathrm{NH}_{4} \mathrm{Cl}$ as the quench, the crude product was purified by flash column chromatography (gradient cyclohexane/EtOAc 100:0 to 50:10) yielding the title compound as a colorless liquid (486 mg, $2.60 \mathrm{mmol}, 84 \%) . \mathrm{R}_{f}=0.16$ (cyclohexan/EtOAc 5:1). ${ }^{1} \mathrm{H} \mathrm{NMR}$ $\left(300 \mathrm{MHz}, \mathrm{CDCl}_{3}\right) \delta 7.31(\mathrm{~d}, J=8.7 \mathrm{~Hz}, 2 \mathrm{H}), 6.91(\mathrm{~d}, J=8.7 \mathrm{~Hz}, 2 \mathrm{H}), 4.84(\mathrm{dd}, J=8.4,3.9 \mathrm{~Hz}, 1 \mathrm{H})$, $3.82(\mathrm{~s}, 3 \mathrm{H}), 3.75-3.58(\mathrm{~m}, 2 \mathrm{H}), 2.87(\mathrm{~s}, 1 \mathrm{H}) .{ }^{13} \mathrm{C} \mathrm{NMR}\left(75 \mathrm{MHz}, \mathrm{CDCl}_{3}\right) \delta 159.6,132.2,127.4,114.1$, $73.7,55.3,50.8$. These data are in agreement with those reported in the literature. ${ }^{\mathrm{S5}}$ 
<smiles>N#Cc1ccc(C(O)CCl)cc1</smiles>

$2 f$ 4-(2-Chloro-1-hydroxyethyl)benzonitrile (2f). After following the general procedure with 4-cyanobenzaldehyde (1f) as the substrate and $2 \mathrm{M}$ aqueous $\mathrm{NH}_{4} \mathrm{Cl}$ as the quench, the crude product was purified by flash column chromatography (gradient cyclohexane/EtOAc 90:10 to 30:10) to obtain the title compound as a colorless oil (507 mg, $2.79 \mathrm{mmol}, 90 \%) . \mathrm{R}_{f}=0.25$ (cyclohexan/EtOAc 3:1). ${ }^{1} \mathrm{H}$ NMR (300 MHz, $\left.\mathrm{CDCl}_{3}\right)$ $\delta 7.76-7.64(\mathrm{~m}, 2 \mathrm{H}), 7.60-7.50(\mathrm{~m}, 2 \mathrm{H}), 5.00(\mathrm{dd}, J=8.3,3.6 \mathrm{~Hz}, 1 \mathrm{H}), 3.78(\mathrm{dd}, J=11.3,3.6 \mathrm{~Hz}, 1 \mathrm{H})$, $3.64(\mathrm{dd}, J=11.3,8.3 \mathrm{~Hz}, 1 \mathrm{H}), 2.71(\mathrm{~s}, 1 \mathrm{H}) .{ }^{13} \mathrm{C} \mathrm{NMR}\left(75 \mathrm{MHz}, \mathrm{CDCl}_{3}\right) \delta 145.1,132.5,126.9,118.5$, $112.2,73.2,50.3$. These data are in agreement with those reported in the literature. ${ }^{\mathrm{S} 8}$

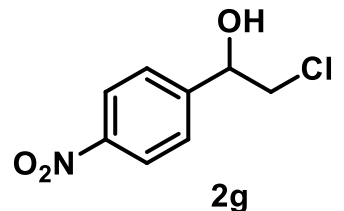

2g

2-Chloro-1-(4-nitrophenyl)ethan-1-ol (2g). After following the general procedure with 4-nitrobenzaldehyde $(\mathbf{1 g})$ as the substrate and $2 \mathrm{M}$ aqueous $\mathrm{NH}_{4} \mathrm{Cl}$ as the quench, the crude product was purified by flash column chromatography (gradient cyclohexane/EtOAc 90:10 to 30:10) to obtain the title compound as a yellow oil (411 mg, $2.04 \mathrm{mmol}, 66 \%) . \mathrm{R}_{f}=0.27$ (cyclohexan/EtOAc 3:1). ${ }^{1} \mathrm{H}$ NMR $\left(300 \mathrm{MHz}, \mathrm{CDCl}_{3}\right) \delta$ $8.25(\mathrm{~d}, J=8.7 \mathrm{~Hz}, 2 \mathrm{H}), 7.61(\mathrm{~d}, J=8.7 \mathrm{~Hz}, 2 \mathrm{H}), 5.06(\mathrm{dd}, J=8.2,3.6 \mathrm{~Hz}, 1 \mathrm{H}), 3.81(\mathrm{dd}, J=11.3,3.6$ $\mathrm{Hz}, 1 \mathrm{H}), 3.66(\mathrm{dd}, J=11.4,8.2 \mathrm{~Hz}, 1 \mathrm{H}), 2.80(\mathrm{~s}, 1 \mathrm{H}) .{ }^{13} \mathrm{C} \mathrm{NMR}\left(75 \mathrm{MHz}, \mathrm{CDCl}_{3}\right) \delta 147.9,146.9,127.0$, 123.9, 73.0, 50.3. These data are in agreement with those reported in the literature. ${ }^{\mathrm{s} 8}$

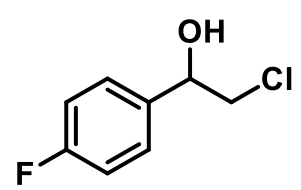

$2 \mathrm{~h}$

2-Chloro-1-(4-fluorophenyl)ethan-1-ol (2h). Following the general procedure with 4-fluorobenzaldehyde (1h) as the substrate and $2 \mathrm{M}$ aqueous $\mathrm{NH}_{4} \mathrm{Cl}$ as the quench, the title compound was obtained without further purification as a colorless liquid (521 mg, $2.98 \mathrm{mmol}, 96 \%) .{ }^{1} \mathrm{H} \mathrm{NMR}\left(300 \mathrm{MHz}, \mathrm{CDCl}_{3}\right) \delta 7.38$ (dd, $J=8.6,5.4 \mathrm{~Hz}$, 2H), $7.08(\mathrm{t}, J=8.7 \mathrm{~Hz}, 2 \mathrm{H}), 4.90(\mathrm{dd}, J=8.6,3.6 \mathrm{~Hz}, 1 \mathrm{H}), 3.78-3.58(\mathrm{~m}, 2 \mathrm{H}), 2.67(\mathrm{~s}, 1 \mathrm{H}) .{ }^{13} \mathrm{C}$ NMR $\left(75 \mathrm{MHz}, \mathrm{CDCl}_{3}\right) \delta 164.3,161.1,135.7,135.7,127.9,127.8,115.7,115.4,73.4,50.8,50.8 .{ }^{19} \mathrm{~F}$ NMR $\left(282 \mathrm{MHz}, \mathrm{CDCl}_{3}\right) \delta-113.5--113.6(\mathrm{~m})$. These data are in agreement with those reported in the literature. ${ }^{\mathrm{S} 7}$

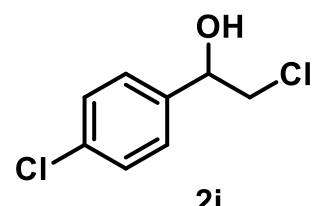

$2 \mathbf{i}$

2-Chloro-1-(4-chlorophenyl)ethan-1-ol (2i). Following the general procedure with 4-chlorobenzaldehyde (1i) as the substrate and $2 \mathrm{M}$ aqueous $\mathrm{NH}_{4} \mathrm{Cl}$ as the quench, the title compound was obtained without further purification as a white solid (568 mg, $2.97 \mathrm{mmol}, 96 \%$ ). M.p. 68-69 ${ }^{\circ} \mathrm{C}$ (lit. ${ }^{\mathrm{S} 6}$ 64-65 ${ }^{\circ} \mathrm{C}$ ) ${ }^{1} \mathrm{H}$ NMR (300 $\left.\mathrm{MHz}, \mathrm{CDCl}_{3}\right) \delta 7.58-7.13(\mathrm{~m}, 4 \mathrm{H}), 4.89(\mathrm{dd}, J=8.5,3.5 \mathrm{~Hz}, 1 \mathrm{H}), 3.73(\mathrm{dd}, J=11.3,3.5 \mathrm{~Hz}, 1 \mathrm{H}), 3.62$ $(\mathrm{dd}, J=11.3,8.5 \mathrm{~Hz}, 1 \mathrm{H}), 2.69$ (s, $1 \mathrm{H}) .{ }^{13} \mathrm{C} \mathrm{NMR}\left(75 \mathrm{MHz}, \mathrm{CDCl}_{3}\right) \delta 138.4,134.2,128.9,127.5,73.4$, 50.7. These data are in agreement with those reported in the literature. ${ }^{\mathrm{S} 6}$ 


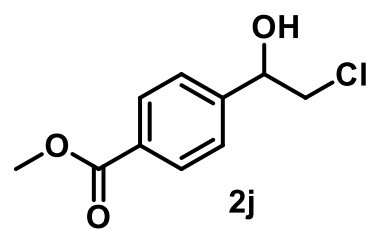

3-(Chloromethyl)isobenzofuran-1(3H)-one (2j). Following the general procedure with methyl 4-formylbenzoate $(\mathbf{1 j})$ as the substrate and $2 \mathrm{M}$ aqueous $\mathrm{NH}_{4} \mathrm{Cl}$ as the quench, the title compound was obtained without further purification as a colorless oil $(641 \mathrm{mg}, 2.99 \mathrm{mmol}, 96 \%) .{ }^{1} \mathrm{H}$ NMR $(300 \mathrm{MHz}$, $\left.\mathrm{CDCl}_{3}\right) \delta 8.05-7.99(\mathrm{~m}, 2 \mathrm{H}), 7.49-7.43(\mathrm{~m}, 2 \mathrm{H}), 4.99-4.91(\mathrm{~m}, 1 \mathrm{H}), 3.91(\mathrm{~s}, 3 \mathrm{H}), 3.74(\mathrm{dd}, J=11.3$, $3.7 \mathrm{~Hz}, 1 \mathrm{H}), 3.63(\mathrm{dd}, J=11.3,8.3 \mathrm{~Hz}, 1 \mathrm{H}), 3.10(\mathrm{~s}, 1 \mathrm{H}) .{ }^{13} \mathrm{C} \mathrm{NMR}\left(75 \mathrm{MHz}, \mathrm{CDCl}_{3}\right) \delta 166.8,145.1$, $130.0,129.9,126.1,73.6,52.3,50.4$. These data are in agreement with those reported in the literature. ${ }^{\mathrm{S} 6}$

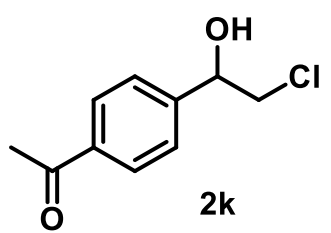

compound as a white solid (567 mg, $2.85 \mathrm{mmol}, 92 \%) . \mathrm{R}_{f}=0.34$ (cyclohexan/EtOAc 5:1). M.p. $54-55^{\circ} \mathrm{C}$ (lit. $\left.{ }^{\mathrm{S} 6} 56-57{ }^{\circ} \mathrm{C}\right) .{ }^{1} \mathrm{H}$ NMR $\left(300 \mathrm{MHz}, \mathrm{CDCl}_{3}\right) \delta 7.96(\mathrm{~d}, J=8.3 \mathrm{~Hz}, 2 \mathrm{H}), 7.57-7.45(\mathrm{~m}, 2 \mathrm{H}), 4.99(\mathrm{dd}, J$ $=8.3,3.6 \mathrm{~Hz}, 1 \mathrm{H}), 3.77(\mathrm{dd}, J=11.3,3.6 \mathrm{~Hz}, 1 \mathrm{H}), 3.65(\mathrm{dd}, J=11.3,8.3 \mathrm{~Hz}, 1 \mathrm{H}), 3.07(\mathrm{~s}, 1 \mathrm{H}), 2.61(\mathrm{~s}$, $3 \mathrm{H}) .{ }^{13} \mathrm{C} \mathrm{NMR}\left(75 \mathrm{MHz}, \mathrm{CDCl}_{3}\right) \delta 197.9,145.2,137.0,128.7,126.3,73.5,50.5,26.7$. These data are in agreement with those reported in the literature. ${ }^{\mathrm{S} 6}$

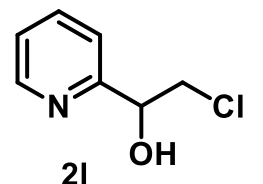

2-Chloro-1-(pyridin-2-yl)ethan-1-ol (2l). After following the general procedure with 2-pyridinecarboxaldehyde (11) as the substrate and $2 \mathrm{M}$ aqueous $\mathrm{NH}_{4} \mathrm{Cl}$ as the quench, the crude product was purified by flash column chromatography (gradient cyclohexane/EtOAc 100:0 to 50:10) to obtain the title compound as a yellow oil (395 mg, $2.51 \mathrm{mmol}, 81 \%) . \mathrm{R}_{f}=0.25$ (cyclohexan/EtOAc 3:1). ${ }^{1} \mathrm{H}$ NMR $\left(300 \mathrm{MHz}, \mathrm{CDCl}_{3}\right) \delta 8.60-8.57$ (m, 1H), 7.76 (ddd, $J=7.8,7.7,1.8 \mathrm{~Hz}, 1 \mathrm{H}), 7.45(\mathrm{~d}, J=7.8 \mathrm{~Hz}, 1 \mathrm{H}), 7.34-7.23(\mathrm{~m}, 1 \mathrm{H}), 5.00(\mathrm{dd}, J=$ 5.4, $5.3 \mathrm{~Hz}, 1 \mathrm{H}), 4.53(\mathrm{~s}, 1 \mathrm{H}), 3.99-3.72(\mathrm{~m}, 2 \mathrm{H}) .{ }^{13} \mathrm{C} \mathrm{NMR}\left(75 \mathrm{MHz}, \mathrm{CDCl}_{3}\right) \delta 158.2,148.4,137.1$, $123.2,121.3,72.7,49.4$. These data are in agreement with those reported in the literature. ${ }^{\mathrm{S} 2}$

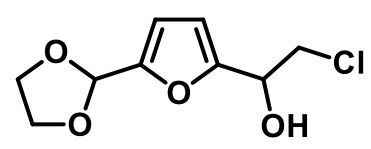

$2 m$

1-(5-(1,3-Dioxolan-2-yl)furan-2-yl)-2-chloroethan-1-ol (2m). Following the general procedure with 5-(1,3-dioxolan-2-yl)furfural (1m) as the substrate and $2 \mathrm{M}$ aqueous $\mathrm{NH}_{4} \mathrm{Cl}$ as the quench, the title compound was obtained without further purification as a yellow oil (663 mg, $3.03 \mathrm{mmol}, 98 \%) .{ }^{1} \mathrm{H}$ NMR (300 $\left.\mathrm{MHz}, \mathrm{CDCl}_{3}\right) \delta 6.40(\mathrm{~d}, J=3.3 \mathrm{~Hz}, 1 \mathrm{H}), 6.31(\mathrm{~d}, J=3.3 \mathrm{~Hz}, 1 \mathrm{H}), 5.87(\mathrm{~s}, 1 \mathrm{H}), 4.87(\mathrm{dd}, J=7.0,4.6 \mathrm{~Hz}$, $1 \mathrm{H}), 4.13-4.03(\mathrm{~m}, 2 \mathrm{H}), 4.01-3.94(\mathrm{~m}, 2 \mathrm{H}), 3.88-3.73(\mathrm{~m}, 2 \mathrm{H}), 3.29(\mathrm{~s}, 1 \mathrm{H}) .{ }^{13} \mathrm{C}$ NMR $(75 \mathrm{MHz}$, $\left.\mathrm{CDCl}_{3}\right) \delta 153.7,150.9,109.5,108.0,97.5,68.0,65.1,65.1,47.4$. HRMS (ESI-TOF): $\mathrm{m} / z[\mathrm{M}+\mathrm{H}]^{+}$calcd. for $\left[\mathrm{C}_{9} \mathrm{H}_{11} \mathrm{O}_{4} \mathrm{Cl}+\mathrm{H}\right]^{+}$219.0418, found 219.0420. 


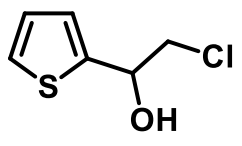

$2 n$

2-Chloro-1-(thiophen-2-yl)ethan-1-ol (2n). Following the general procedure with 2thiophenecarboxyldehyde (1n) as the substrate and $2 \mathrm{M}$ aqueous $\mathrm{NH}_{4} \mathrm{Cl}$ as the quench, the title compound was obtained without further purification as a yellow oil (478 $\mathrm{mg}$, $2.94 \mathrm{mmol}, 95 \%) .{ }^{1} \mathrm{H}$ NMR $\left(300 \mathrm{MHz}, \mathrm{CDCl}_{3}\right) \delta 7.32(\mathrm{dd}, J=5.0,1.3 \mathrm{~Hz}, 1 \mathrm{H}), 7.11$ $6.97(\mathrm{~m}, 2 \mathrm{H}), 5.17(\mathrm{ddd}, J=7.8,4.1,0.8 \mathrm{~Hz}, 1 \mathrm{H}), 3.91-3.66(\mathrm{~m}, 2 \mathrm{H}), 3.02(\mathrm{~s}, 1 \mathrm{H}) .{ }^{13} \mathrm{C}$ NMR $(75 \mathrm{MHz}$, $\left.\mathrm{CDCl}_{3}\right) \delta 143.3,127.0,125.5,124.8,70.3,50.4$. These data are in agreement with those reported in the literature. ${ }^{\mathrm{S} 4}$

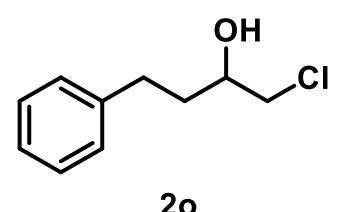

20

1-Chloro-4-phenylbutan-2-ol (2o). After following the general procedure with 3phenylpropanal (10) as the substrate and $2 \mathrm{M}$ aqueous $\mathrm{NH}_{4} \mathrm{Cl}$ as the quench, the crude product was purified by flash column chromatography (gradient cyclohexane/EtOAc 100:0 to 50:10) to obtain the title compound as a colorless liquid (409 mg, $2.21 \mathrm{mmol}, 71 \%$ ). $\mathrm{R}_{f}=0.28$ (cyclohexan/EtOAc 5:1). ${ }^{1} \mathrm{H}$ NMR $\left(300 \mathrm{MHz}, \mathrm{CDCl}_{3}\right) \delta$ $7.38-7.27(\mathrm{~m}, 2 \mathrm{H}), 7.26-7.20(\mathrm{~m}, 3 \mathrm{H}), 3.90-3.79(\mathrm{~m}, 1 \mathrm{H}), 3.66(\mathrm{dd}, J=11.1,3.3 \mathrm{~Hz}, 1 \mathrm{H}), 3.52(\mathrm{dd}, J$ $=11.1,7.0 \mathrm{~Hz}, 1 \mathrm{H}), 2.93-2.66(\mathrm{~m}, 2 \mathrm{H}), 2.21(\mathrm{~s}, 1 \mathrm{H}), 1.97-1.81(\mathrm{~m}, 2 \mathrm{H}) .{ }^{13} \mathrm{C} \mathrm{NMR}\left(75 \mathrm{MHz}, \mathrm{CDCl}_{3}\right) \delta$ $141.3,128.5,128.5,126.1,70.6,50.6,35.8,31.8$. These data are in agreement with those reported in the literature. ${ }^{\mathrm{S} 5}$

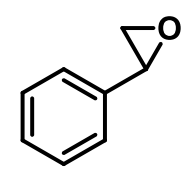

$3 a$

2-Phenyloxirane (3a). Following the general procedure with benzaldehyde (1a) as the substrate and $1 \mathrm{M}$ aqueous $\mathrm{NaOH}$ as the quench, the title compound was obtained without further purification as a colorless liquid $(309 \mathrm{mg}, 2.57 \mathrm{mmol}, 83 \%) .{ }^{1} \mathrm{H} \mathrm{NMR}(300 \mathrm{MHz}$, $\left.\mathrm{CDCl}_{3}\right) \delta 7.69-7.18(\mathrm{~m}, 5 \mathrm{H}), 3.89(\mathrm{dd}, J=4.1,2.6 \mathrm{~Hz}, 1 \mathrm{H}), 3.18(\mathrm{dd}, J=5.5,4.1 \mathrm{~Hz}, 1 \mathrm{H})$, $2.83(\mathrm{dd}, J=5.5,2.6 \mathrm{~Hz}, 1 \mathrm{H}) .{ }^{13} \mathrm{C} \mathrm{NMR}\left(75 \mathrm{MHz}, \mathrm{CDCl}_{3}\right) \delta 137.6,128.5,128.2,125.5,52.4,51.3$. These data are in agreement with those reported in the literature. ${ }^{\mathrm{S} 11}$

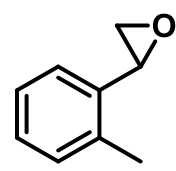

$3 b$

2-(o-Tolyl)oxirane (3b). After following the general procedure with 2-methylbenzaldehyde (1b) as the substrate and $1 \mathrm{M}$ aqueous $\mathrm{NaOH}$ as the quench, the crude product was purified by flash column chromatography (gradient cyclohexane/EtOAc 100:0 to 90:10) to obtain the title compound as a colorless liquid (370 mg, $2.76 \mathrm{mmol}, 89 \%) . \quad \mathrm{R}_{f}=0.35$ (cyclohexane/EtOAc 5:1). ${ }^{1} \mathrm{H}$ NMR $\left(300 \mathrm{MHz}, \mathrm{CDCl}_{3}\right) \delta 7.30-7.18(\mathrm{~m}, 4 \mathrm{H}), 4.05(\mathrm{dd}, J=4.1,2.7 \mathrm{~Hz}$, $1 \mathrm{H}), 3.20(\mathrm{dd}, J=5.7,4.1 \mathrm{~Hz}, 1 \mathrm{H}), 2.74(\mathrm{dd}, J=5.7,2.6 \mathrm{~Hz}, 1 \mathrm{H}), 2.47(\mathrm{~s}, 3 \mathrm{H}) .{ }^{13} \mathrm{C} \mathrm{NMR}(75 \mathrm{MHz}$, $\left.\mathrm{CDCl}_{3}\right) \delta 136.2,135.2,129.9,127.7,126.2,124.1,50.5,50.2,18.8$. These data are in agreement with those reported in the literature. ${ }^{\mathrm{S} 12}$

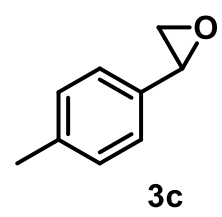

2-(p-Tolyl)oxirane (3c). Following the general procedure with 4-methylbenzaldehyde

(1c) as the substrate and $1 \mathrm{M}$ aqueous $\mathrm{NaOH}$ as the quench, the title compound was 
obtained without further purification as colorless liquid (397 mg, $2.96 \mathrm{mmol}, 95 \%) .{ }^{1} \mathrm{H} \mathrm{NMR} \mathrm{(300} \mathrm{MHz,}$ $\left.\mathrm{CDCl}_{3}\right) \delta 7.22-7.19(\mathrm{~m}, 4 \mathrm{H}), 3.87(\mathrm{dd}, J=4.1,2.6 \mathrm{~Hz}, 1 \mathrm{H}), 3.16(\mathrm{dd}, J=5.5,4.1 \mathrm{~Hz}, 1 \mathrm{H}), 2.84(\mathrm{dd}, J=$ 5.5, $2.6 \mathrm{~Hz}, 1 \mathrm{H}), 2.39$ (s, 3H). ${ }^{13} \mathrm{C}$ NMR $\left(75 \mathrm{MHz}, \mathrm{CDCl}_{3}\right) \delta 138.0,134.6,129.2,125.5,52.4,51.1,21.2$. These data are in agreement with those reported in the literature. ${ }^{\mathrm{S} 11}$

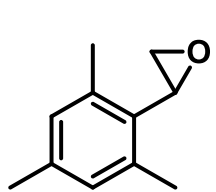

$3 d$

2-Mesityloxirane (3d). Following the general procedure with 2,4,6trimethylbenzaldehyde (1d) as the substrate and $1 \mathrm{M}$ aqueous $\mathrm{NaOH}$ as the quench, the title compound was obtained without further purification as white solid ( $489 \mathrm{mg}$, $3.01 \mathrm{mmol}, 97 \%)$. M.p. $38-39{ }^{\circ} \mathrm{C}$ (lit. $\left.{ }^{\mathrm{S} 18} 29{ }^{\circ} \mathrm{C}\right) .{ }^{1} \mathrm{H}$ NMR $\left(300 \mathrm{MHz}, \mathrm{CDCl}_{3}\right) \delta 6.92$ (s, 2H), $3.98(\mathrm{dd}, J=3.9,3.0 \mathrm{~Hz}, 1 \mathrm{H}), 3.24(\mathrm{dd}, J=5.6,4.1 \mathrm{~Hz}, 1 \mathrm{H}), 2.82(\mathrm{dd}, J=5.6,2.9 \mathrm{~Hz}, 1 \mathrm{H}), 2.46(\mathrm{~s}$, $6 \mathrm{H}), 2.36(\mathrm{~s}, 3 \mathrm{H}) .{ }^{13} \mathrm{C}$ NMR $\left(75 \mathrm{MHz}, \mathrm{CDCl}_{3}\right) \delta 137.4,137.2,131.2,128.7,51.0,48.7,21.0$, 19.7. These data are in agreement with those reported in the literature. ${ }^{\mathrm{S} 13}$

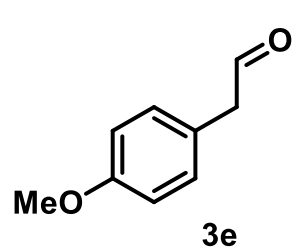

2-(4-Methoxyphenyl)acetaldehyde (3e). After following the general procedure with 4-methoxybenzaldehyde (1e) as the substrate and $1 \mathrm{M}$ aqueous $\mathrm{NaOH}$ as the quench, the crude product was purified by flash column chromatography (gradient cyclohexane/EtOAc 100:0 to 90:10). The expected oxirane rearranged to the title compound, which was isolated as a colorless liquid (392 mg, $2.61 \mathrm{mmol}, 84 \%$ ). $\mathrm{R}_{f}=0.18$ (cyclohexane/EtOAc 5:1). ${ }^{1} \mathrm{H}$ NMR $\left(300 \mathrm{MHz}, \mathrm{CDCl}_{3}\right) \delta 9.74(\mathrm{t}, J=2.4 \mathrm{~Hz}, 1 \mathrm{H}), 7.16(\mathrm{~d}, J=$ $8.6 \mathrm{~Hz}, 2 \mathrm{H}), 6.93(\mathrm{~d}, J=8.6 \mathrm{~Hz}, 2 \mathrm{H}), 3.83(\mathrm{~s}, 3 \mathrm{H}), 3.65(\mathrm{~d}, J=2.4 \mathrm{~Hz}, 2 \mathrm{H}) .{ }^{13} \mathrm{C} \mathrm{NMR}\left(75 \mathrm{MHz}, \mathrm{CDCl}_{3}\right)$ $\delta 199.7,159.0,130.7,123.7,114.5,55.3,49.7$. These data are in agreement with those reported in the literature. ${ }^{\mathrm{S} 15}$

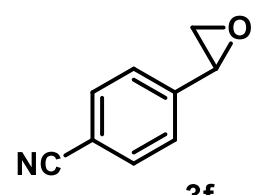

$3 f$

4-(Oxiran-2-yl)benzonitrile (3f). After following the general procedure with 4cyanobenzaldehyde (1f) as the substrate and $1 \mathrm{M}$ aqueous $\mathrm{NaOH}$ as the quench, the crude product was purified by flash column chromatography (gradient cyclohexane/EtOAc 100:0 to 90:10) to obtain the title compound as a white solid (348 mg, 2.40 mmol, 77\%). $\mathrm{R}_{f}=0.46$ (cyclohexan/EtOAc 3:1). M.p. 59-60 ${ }^{\circ} \mathrm{C}$ (lit. ${ }^{\mathrm{S} 19} 34{ }^{\circ} \mathrm{C}$ ). ${ }^{1} \mathrm{H}$ NMR $\left(300 \mathrm{MHz}, \mathrm{CDCl}_{3}\right) \delta 7.71-7.57(\mathrm{~m}, 2 \mathrm{H}), 7.44-7.35(\mathrm{~m}, 2 \mathrm{H}), 3.91(\mathrm{dd}, J=4.1,2.5 \mathrm{~Hz}, 1 \mathrm{H}), 3.21(\mathrm{dd}, J$ $=5.5,4.1 \mathrm{~Hz}, 1 \mathrm{H}), 2.76(\mathrm{dd}, J=5.5,2.4 \mathrm{~Hz}, 1 \mathrm{H}) .{ }^{13} \mathrm{C} \mathrm{NMR}\left(75 \mathrm{MHz}, \mathrm{CDCl}_{3}\right) \delta 143.3,132.4,126.1$, $118.7,111.9,51.6$. These data are in agreement with those reported in the literature. ${ }^{\mathrm{S} 19}$

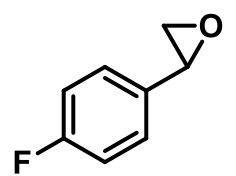

$3 \mathrm{~h}$

2-(4-Fluorophenyl)oxirane (3h). After following the general procedure with 4fluorobenzaldehyde (1h) as the substrate and $1 \mathrm{M}$ aqueous $\mathrm{NaOH}$ as the quench, the crude product was purified by flash column chromatography (gradient cyclohexane/EtOAc 100:0 to 90:10) to obtain the title compound as a colorless liquid 
(396 mg, $2.87 \mathrm{mmol}, 92 \%) . \mathrm{R}_{f}=0.22\left(\right.$ cyclohexan/EtOAc 5:1). ${ }^{1} \mathrm{H}$ NMR $\left(300 \mathrm{MHz}, \mathrm{CDCl}_{3}\right) \delta 7.32-7.19$ (m, 2H), $7.11-6.96(\mathrm{~m}, 2 \mathrm{H}), 3.86(\mathrm{dd}, J=4.1,2.6 \mathrm{~Hz}, 1 \mathrm{H}), 3.15(\mathrm{dd}, J=5.4,4.0 \mathrm{~Hz}, 1 \mathrm{H}), 2.78(\mathrm{dd}, J=$ 5.4, $2.5 \mathrm{~Hz}, 1 \mathrm{H}) .{ }^{13} \mathrm{C} \mathrm{NMR}\left(75 \mathrm{MHz}, \mathrm{CDCl}_{3}\right) \delta 164.3,161.1,133.4,133.3,127.2,127.1,115.6,115.3$, 51.8, 51.2. ${ }^{19} \mathrm{~F}$ NMR $\left(282 \mathrm{MHz}, \mathrm{CDCl}_{3}\right) \delta-110.6--115.5(\mathrm{~m})$. These data are in agreement with those reported in the literature. ${ }^{\mathrm{S} 14}$

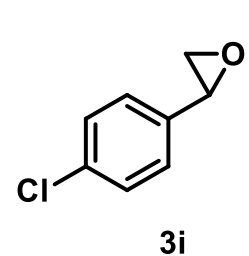

$3 \mathbf{i}$

2-(4-Chlorophenyl)oxirane (3i). Following the general procedure with 4chlorobenzaldehyde (1i) as the substrate and $1 \mathrm{M}$ aqueous $\mathrm{NaOH}$ as the quench, the title compound was obtained without further purification as a colorless oil (441 mg, $2.85 \mathrm{mmol}, 92 \%) .{ }^{1} \mathrm{H}$ NMR $\left(300 \mathrm{MHz}, \mathrm{CDCl}_{3}\right) \delta 7.38-7.31(\mathrm{~m}, 2 \mathrm{H}), 7.25-7.18(\mathrm{~m}$, 2H), $3.85(\mathrm{dd}, J=4.1,2.5 \mathrm{~Hz}, 1 \mathrm{H}), 3.16(\mathrm{dd}, J=5.5,4.1 \mathrm{~Hz}, 1 \mathrm{H}), 2.77$ (dd, $J=5.5,2.6$ $\mathrm{Hz}, 1 \mathrm{H}) .{ }^{13} \mathrm{C} \mathrm{NMR}\left(75 \mathrm{MHz}, \mathrm{CDCl}_{3}\right) \delta 136.2,133.9,128.7,126.9,51.8,51.3$. These data are in agreement with those reported in the literature. ${ }^{\mathrm{S} 11}$

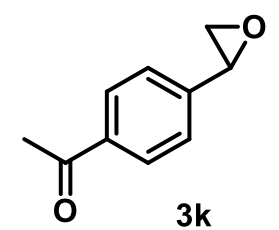

1-(4-(Oxiran-2-yl)phenyl)ethan-1-one (3k). After following the general procedure with 4-formylacetophenone (1k) as the substrate and $1 \mathrm{M}$ aqueous $\mathrm{NaOH}$ as the quench, the crude product was purified by flash column chromatography (gradient cyclohexane/EtOAc 100:0 to 90:10) to obtain the title compound as a colorless oil (441 mg, $2.72 \mathrm{mmol}, 88 \%) . \mathrm{R}_{f}=0.17$ (cyclohexan/EtOAc 5:1). ${ }^{1} \mathrm{H}$ NMR $\left(300 \mathrm{MHz}, \mathrm{CDCl}_{3}\right) \delta 8.04-7.86$ (m, 2H), $7.43-7.34(\mathrm{~m}, 2 \mathrm{H}), 3.91(\mathrm{dd}, J=4.1,2.5 \mathrm{~Hz}, 1 \mathrm{H}), 3.19(\mathrm{dd}, J=5.5,4.1 \mathrm{~Hz}, 1 \mathrm{H}), 2.79(\mathrm{dd}, J=$ 5.6, $2.5 \mathrm{~Hz}, 1 \mathrm{H}), 2.60(\mathrm{~s}, 3 \mathrm{H}) .{ }^{13} \mathrm{C} \mathrm{NMR}\left(75 \mathrm{MHz}, \mathrm{CDCl}_{3}\right) \delta 197.6,143.1,136.9,128.6,125.6,51.9,51.5$, 26.7. HRMS (ESI-TOF): $\mathrm{m} / z[\mathrm{M}+\mathrm{H}]^{+}$calcd. for $\left[\mathrm{C}_{10} \mathrm{H}_{10} \mathrm{O}_{2}+\mathrm{H}\right]^{+} 163.0754$, found 163.0753. $\mathrm{m} / z[\mathrm{M}-\mathrm{H}]^{-}$ calcd. for $\left[\mathrm{C}_{10} \mathrm{H}_{10} \mathrm{O}_{2}-\mathrm{H}\right]^{-} 161.0608$, found 161.0609 .

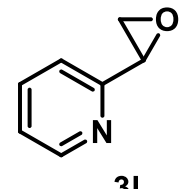

2-(Oxiran-2-yl)pyridine (31). After following the general procedure with 2-pyridinecarboxyldehyde (11) as the substrate and $1 \mathrm{M}$ aqueous $\mathrm{NaOH}$ as the quench, the crude product was purified by flash column chromatography (gradient cyclohexane/EtOAc 100:0 to 90:10) to obtain the title compound as a yellow oil (304 mg, $2.51 \mathrm{mmol}, 81 \%$ ). $\mathrm{R}_{f}=0.10$ (cyclohexane/EtOAc 5:1). ${ }^{1} \mathrm{H}$ NMR $\left(300 \mathrm{MHz}, \mathrm{CDCl}_{3}\right) \delta 8.62-8.44(\mathrm{~m}, 1 \mathrm{H}), 7.70-7.61(\mathrm{~m}$, $1 \mathrm{H}), 7.24-7.15(\mathrm{~m}, 2 \mathrm{H}), 3.99(\mathrm{dd}, J=4.1,2.5 \mathrm{~Hz}, 1 \mathrm{H}), 3.16(\mathrm{dd}, J=5.8,4.1 \mathrm{~Hz}, 1 \mathrm{H}), 2.92(\mathrm{dd}, J=5.8$, $2.5 \mathrm{~Hz}, 1 \mathrm{H}) .{ }^{13} \mathrm{C} \mathrm{NMR}\left(75 \mathrm{MHz}, \mathrm{CDCl}_{3}\right) \delta 157.2,149.4,136.8,123.1,119.7,52.8,50.4$. These data are in agreement with those reported in the literature. ${ }^{\mathrm{S} 16}$

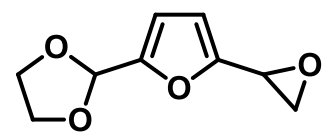

$3 m$
2-(5-(Oxiran-2-yl)furan-2-yl)-1,3-dioxolane (3m). Following the general procedure with 5-(1,3-dioxolan-2-yl)furfural (1m) as the substrate and $1 \mathrm{M}$ 
aqueous $\mathrm{NaOH}$ as the quench, the title compound was obtained as a pale yellow oil (545 $\mathrm{mg}, 2.99 \mathrm{mmol}$, 96\%). The crude material is sensitive towards air and thus it could not be isolated using flash column chromatography. ${ }^{1} \mathrm{H}$ NMR $\left(300 \mathrm{MHz}, \mathrm{CDCl}_{3}\right) \delta 6.42-6.36(\mathrm{~m}, 2 \mathrm{H}), 5.88(\mathrm{~s}, 1 \mathrm{H}), 4.14-4.05(\mathrm{~m}, 2 \mathrm{H})$, $4.02-3.94(\mathrm{~m}, 2 \mathrm{H}), 3.86(\mathrm{dd}, J=4.2,2.7 \mathrm{~Hz}, 1 \mathrm{H}), 3.24-3.17(\mathrm{~m}, 1 \mathrm{H}), 3.12(\mathrm{dd}, J=5.4,4.2 \mathrm{~Hz}, 1 \mathrm{H})$. ${ }^{13} \mathrm{C}$ NMR $\left(75 \mathrm{MHz}, \mathrm{CDCl}_{3}\right) \delta 151.6,151.2,109.9,109.6,97.5,65.2,65.1,48.0,46.2$. HRMS (ESI-TOF): $m / z[\mathrm{M}+\mathrm{H}]^{+}$calcd. for $\left[\mathrm{C}_{9} \mathrm{H}_{10} \mathrm{O}_{4}+\mathrm{H}\right]^{+}$183.0652, found 183.0651. $\mathrm{m} / z[\mathrm{M}-\mathrm{H}]^{-}$calcd. for $\left[\mathrm{C}_{9} \mathrm{H}_{10} \mathrm{O}_{4}-\mathrm{H}\right]$ 181.0506, found 181.0506 .

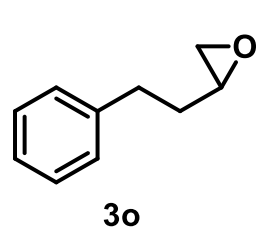

(274 mg, $1.85 \mathrm{mmol}, 60 \%) . \mathrm{R}_{f}=0.36$ (cyclohexane/EtOAc 5:1). ${ }^{1} \mathrm{H}$ NMR $\left(300 \mathrm{MHz}, \mathrm{CDCl}_{3}\right) \delta 7.37-$ $7.27(\mathrm{~m}, 2 \mathrm{H}), 7.28-7.17(\mathrm{~m}, 3 \mathrm{H}), 3.05-2.94(\mathrm{~m}, 1 \mathrm{H}), 2.89-2.75(\mathrm{~m}, 3 \mathrm{H}), 2.50$ (dd, J = 5.0, $2.7 \mathrm{~Hz}$, 1H), $1.97-1.83(\mathrm{~m}, 2 \mathrm{H}) .{ }^{13} \mathrm{C} \mathrm{NMR}\left(75 \mathrm{MHz}, \mathrm{CDCl}_{3}\right) \delta 141.3,128.5,128.4,126.0,51.8,47.3,34.3,32.3$. These data are in agreement with those reported in the literature. ${ }^{\mathrm{S} 12}$

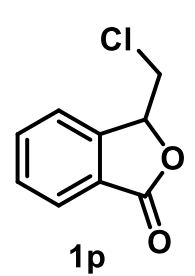

Methyl 4-(2-chloro-1-hydroxyethyl)benzoate (4). Following the general procedure with methyl 2-formylbenzoate (1p) as the substrate and $2 \mathrm{M} \mathrm{NH}_{4} \mathrm{Cl}$ as the quench, the title compound was obtained without further purification as a colorless liquid $(540 \mathrm{mg}$, $2.96 \mathrm{mmol}, 95 \%) .{ }^{1} \mathrm{H} \mathrm{NMR}\left(300 \mathrm{MHz}, \mathrm{CDCl}_{3}\right) \delta 7.92(\mathrm{dt}, J=7.6,1.0 \mathrm{~Hz}, 1 \mathrm{H}), 7.72(\mathrm{dd}, J$ $=7.4,1.2 \mathrm{~Hz}, 1 \mathrm{H}), 7.66-7.56(\mathrm{~m}, 2 \mathrm{H}), 5.70(\mathrm{t}, J=5.0 \mathrm{~Hz}, 1 \mathrm{H}), 3.94(\mathrm{~d}, J=5.0 \mathrm{~Hz}, 2 \mathrm{H})$. ${ }^{13} \mathrm{C}$ NMR $\left(75 \mathrm{MHz}, \mathrm{CDCl}_{3}\right) \delta 169.6,146.6,134.4,130.0,126.4,125.9,122.5,79.1,44.6$. These data are in agreement with those reported in the literature. ${ }^{\mathrm{S} 6}$

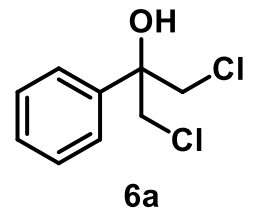

1,3-Dichloro-2-phenylpropan-2-ol (6a). After following the general procedure with 2chloroacetophenone (5a) as the substrate and $2 \mathrm{M}$ aqueous $\mathrm{NH}_{4} \mathrm{Cl}$ as the quench, the crude product was purified by flash column chromatography (gradient cyclohexane/EtOAc 100:0 to 50:10) to obtain the title compound as a colorless liquid (370 mg, $1.80 \mathrm{mmol}, 58 \%) . \mathrm{R}_{f}=0.28$ (cyclohexane/EtOAc 5:1). ${ }^{1} \mathrm{H}$ NMR $\left(300 \mathrm{MHz}, \mathrm{CDCl}_{3}\right) \delta 7.57-$ $7.51(\mathrm{~m}, 2 \mathrm{H}), 7.49-7.35(\mathrm{~m}, 3 \mathrm{H}), 4.05-3.92(\mathrm{~m}, 4 \mathrm{H}), 2.98(\mathrm{~s}, 1 \mathrm{H}) .{ }^{13} \mathrm{C} \mathrm{NMR}\left(75 \mathrm{MHz}, \mathrm{CDCl}_{3}\right) \delta 140.1$, $128.6,128.5,125.7,75.6,50.7$. These data are in agreement with those reported in the literature. ${ }^{\mathrm{S} 9}$

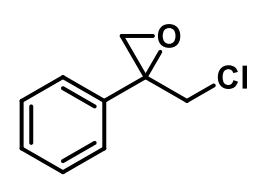

$7 a$

2-(Chloromethyl)-2-phenyloxirane (7a). After following the general procedure with 2-chloroacetophenone (5a) as the substrate and $1 \mathrm{M}$ aqueous $\mathrm{NaOH}$ as the quench, the crude product was purified by flash column chromatography (gradient 
cyclohexane/EtOAc 100:0 to 90:10) to obtain the title compound as a colorless liquid (298 mg, 1.77 mmol, 57\%). $\mathrm{R}_{f}=0.19$ (cyclohexane/EtOAc 5:1). ${ }^{1} \mathrm{H}$ NMR $\left(300 \mathrm{MHz}, \mathrm{CDCl}_{3}\right) \delta 7.58-7.25(\mathrm{~m}$, $5 \mathrm{H}), 4.09(\mathrm{~d}, J=12.0 \mathrm{~Hz}, 1 \mathrm{H}), 3.87(\mathrm{~d}, J=12.0 \mathrm{~Hz}, 1 \mathrm{H}), 3.23(\mathrm{~d}, J=5.2 \mathrm{~Hz}, 1 \mathrm{H}), 2.95(\mathrm{~d}, J=5.2 \mathrm{~Hz}$, $1 \mathrm{H}) .{ }^{13} \mathrm{C} \mathrm{NMR}\left(75 \mathrm{MHz}, \mathrm{CDCl}_{3}\right) \delta 136.7,128.5,128.4,126.3,59.4,55.3,48.0$. These data are in agreement with those reported in the literature. ${ }^{\mathrm{S}}$

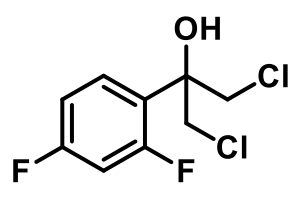

6b

1,3-Dichloro-2-(2,4-difluorophenyl)propan-2-ol (6b). After following the general procedure with 2-chloro-1-(2,4-difluorophenyl)ethan-1-one (5b) as the substrate and $1 \mathrm{M}$ aqueous $\mathrm{NaOH}$ as the quench, the crude product was purified by flash column chromatography (gradient cyclohexane/EtOAc 100:0 to 50:10) to obtain the title compound as a brown oil (376 mg, $1.56 \mathrm{mmol}, \quad 50 \%) . \quad \mathrm{R}_{f}=0.28$ (cyclohexane/EtOAc 5:1). ${ }^{1} \mathrm{H}$ NMR $\left(300 \mathrm{MHz}, \mathrm{CDCl}_{3}\right) \delta 7.69(\mathrm{td}, J=9.0,6.5 \mathrm{~Hz}, 1 \mathrm{H}), 6.95$ (tdd, $J=8.8$, 2.6, $0.9 \mathrm{~Hz}, 1 \mathrm{H}), 6.83$ (ddd, $J=12.1,8.5,2.6 \mathrm{~Hz}, 1 \mathrm{H}), 4.03$ (s, 4H), 3.07 (s, 1H). ${ }^{13} \mathrm{C}$ NMR $(75 \mathrm{MHz}$, $\left.\mathrm{CDCl}_{3}\right) \delta 162.8(\mathrm{dd}, J=304.9,12.5 \mathrm{~Hz}), 159.4(\mathrm{dd}, J=302.2,12.5 \mathrm{~Hz}), 130.4(\mathrm{dd}, J=9.6,5.5 \mathrm{~Hz}), 123.0$ $(\mathrm{dd}, J=12.3,3.9 \mathrm{~Hz}), 111.8(\mathrm{dd}, J=20.7,3.6 \mathrm{~Hz}), 104.5(\mathrm{dd}, J=27.6,25.6 \mathrm{~Hz}), 75.1(\mathrm{~d}, J=4.8 \mathrm{~Hz})$, $49.9(\mathrm{dd}, J=6.0,1.1 \mathrm{~Hz}) .{ }^{19} \mathrm{~F}$ NMR $\left(282 \mathrm{MHz}, \mathrm{CDCl}_{3}\right) \delta-109.4--109.6(\mathrm{~m}),-109.6--109.8(\mathrm{~m})$. These data are in agreement with those reported in the literature. ${ }^{\mathrm{S} 10}$

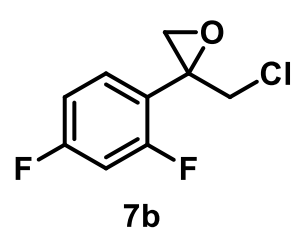

2-(Chloromethyl)-2-(2,4-difluorophenyl)oxirane (7b). After following the general procedure with a $0.2 \mathrm{M}$ solution of 2-chloro-1-(2,4-difluorophenyl)ethan-1-one (5b) as the substrate solution and $1 \mathrm{M}$ aqueous $\mathrm{NaOH}$ as the quench, the crude product was purified by flash column chromatography (gradient cyclohexane/EtOAc 100:0 to $90: 10)$ to obtain the title compound as a white solid $(602 \mathrm{mg}, 2.94 \mathrm{mmol}, 95 \%) . \mathrm{R}_{f}=0.21$ (cyclohexane/EtOAc 5:1). M.p. 55-56 ${ }^{\circ} \mathrm{C}$ (lit. ${ }^{\mathrm{S} 20} 42{ }^{\circ} \mathrm{C}$ ). ${ }^{1} \mathrm{H}$ NMR $\left(300 \mathrm{MHz}, \mathrm{CDCl}_{3}\right) \delta 7.54-7.40(\mathrm{~m}$, 1H), $6.99-6.77(\mathrm{~m}, 2 \mathrm{H}), 4.10(\mathrm{dd}, J=12.0,0.8 \mathrm{~Hz}, 1 \mathrm{H}), 3.70(\mathrm{~d}, J=12.0 \mathrm{~Hz}, 1 \mathrm{H}), 3.22(\mathrm{~d}, J=5.0 \mathrm{~Hz}$, $1 \mathrm{H}), 2.95(\mathrm{~d}, J=5.0 \mathrm{~Hz}, 1 \mathrm{H}) .{ }^{13} \mathrm{C} \mathrm{NMR}\left(75 \mathrm{MHz}, \mathrm{CDCl}_{3}\right) \delta 163.1(\mathrm{dd}, J=250.2,11.9 \mathrm{~Hz}), 160.6(\mathrm{dd}, J=$ 249.2, $12.1 \mathrm{~Hz}), 130.6(\mathrm{dd}, J=9.9,5.5 \mathrm{~Hz}), 120.2(\mathrm{dd}, J=14.8,3.8 \mathrm{~Hz}), 111.5(\mathrm{dd}, J=21.3,3.7 \mathrm{~Hz})$, $103.9(\mathrm{t}, J=25.4 \mathrm{~Hz}), 56.8,53.6,48.2(\mathrm{~d}, J=3.1 \mathrm{~Hz}) .{ }^{19} \mathrm{~F}$ NMR $\left(282 \mathrm{MHz}, \mathrm{CDCl}_{3}\right) \delta-108.9--109.2$ $(\mathrm{m}),-112.4--112.7(\mathrm{~m})$. These data are in agreement with those reported in the literature. ${ }^{\mathrm{S} 20}$ 
S17

9. Copies of NMR Spectra
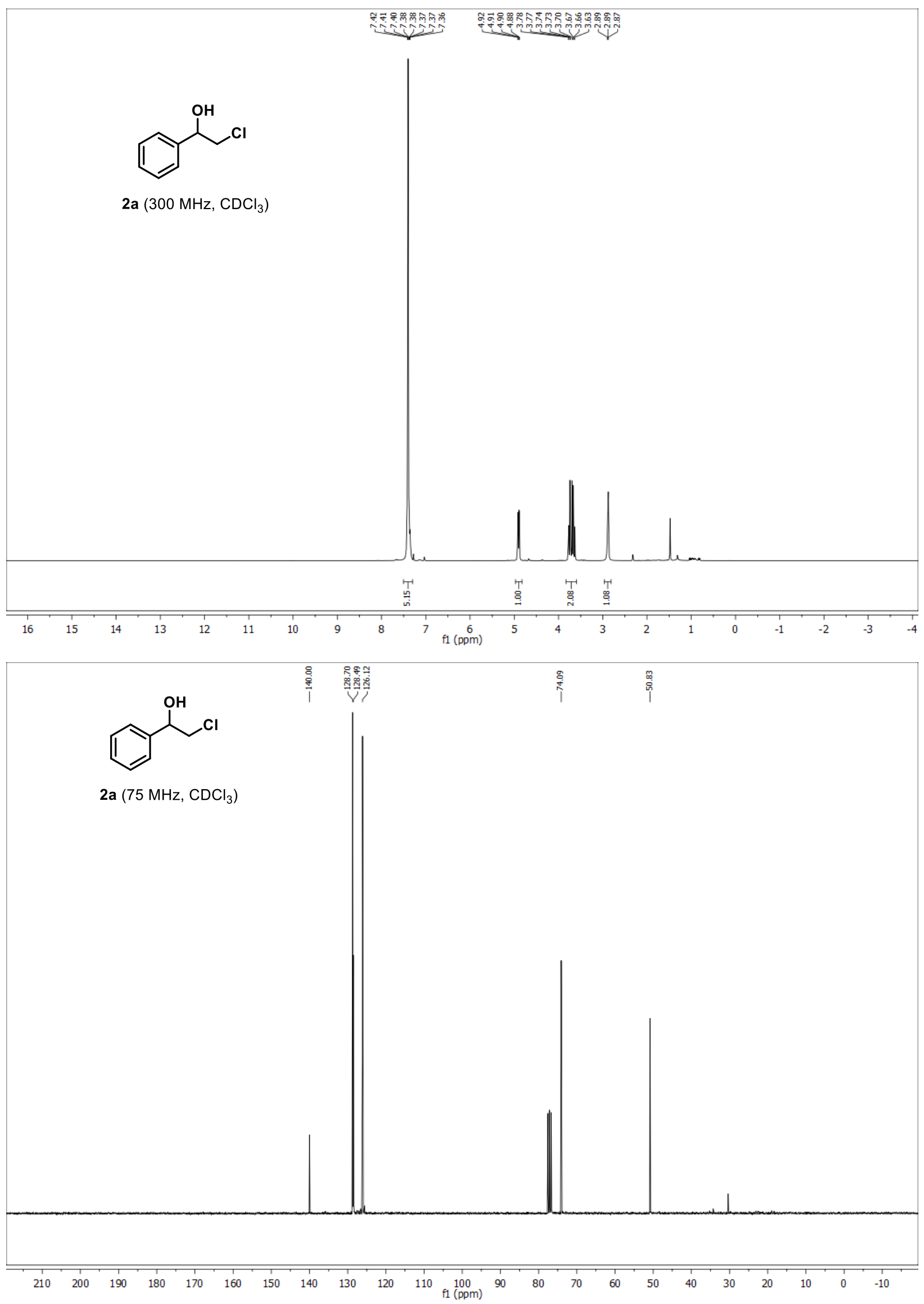

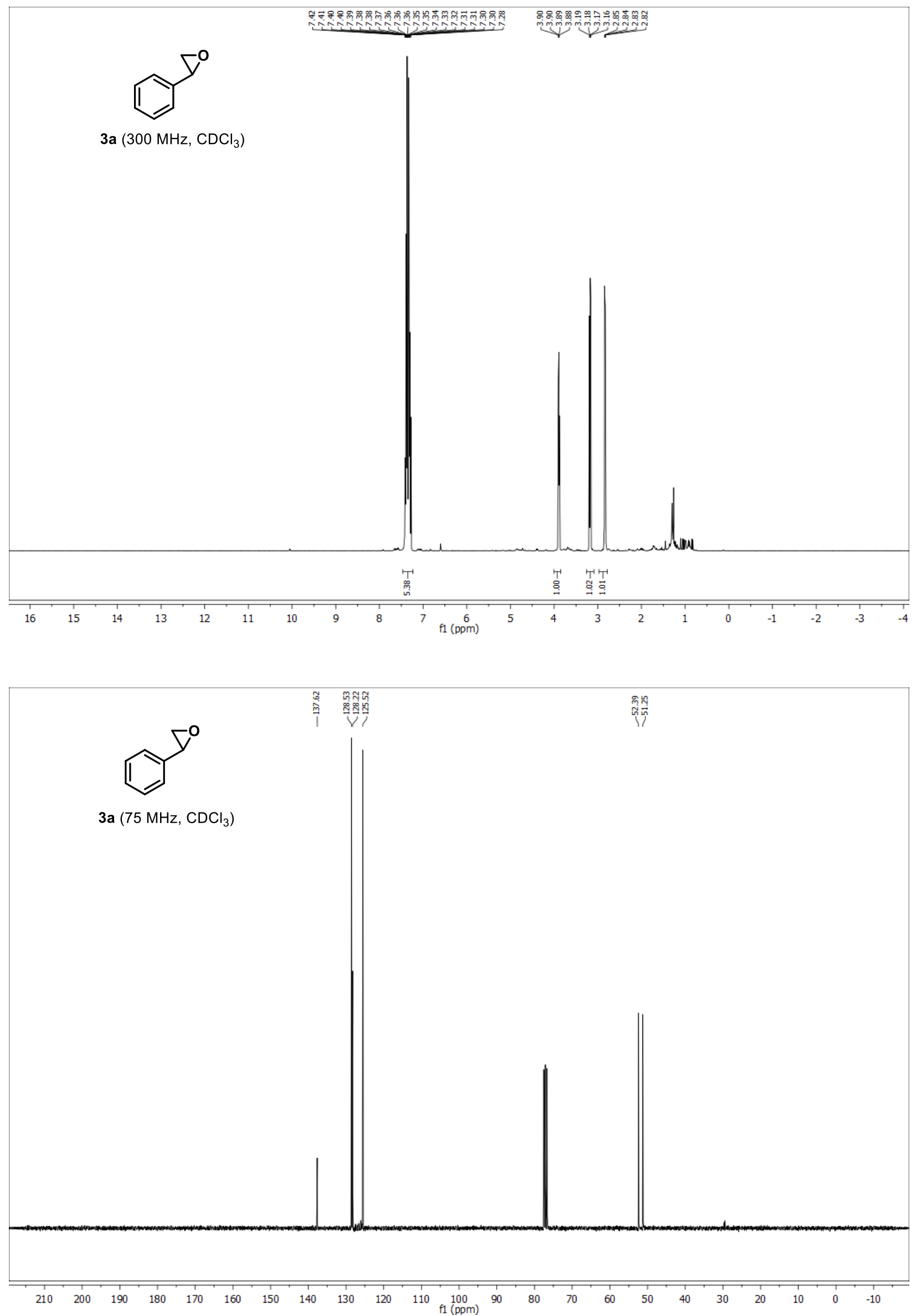
S19
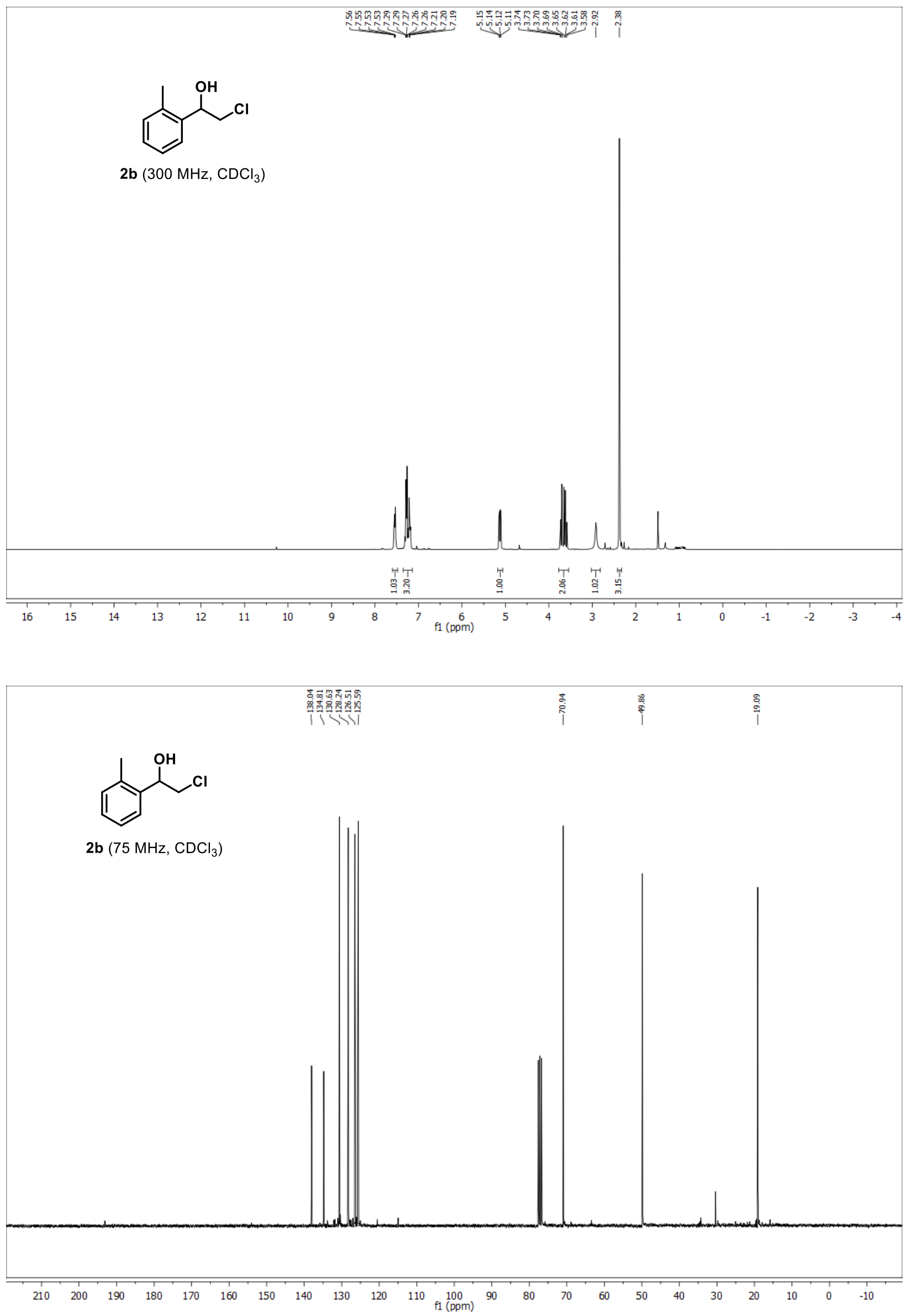

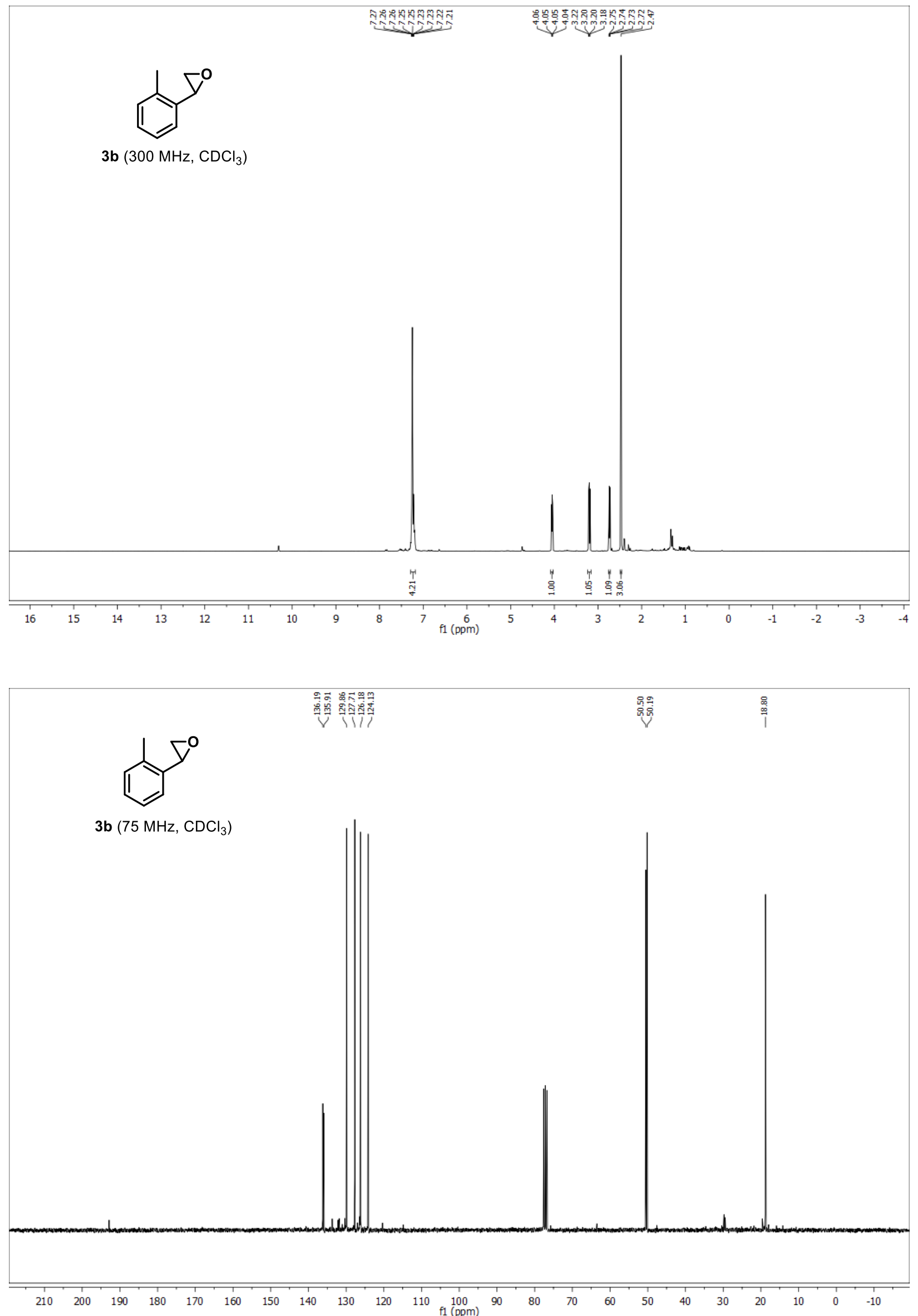

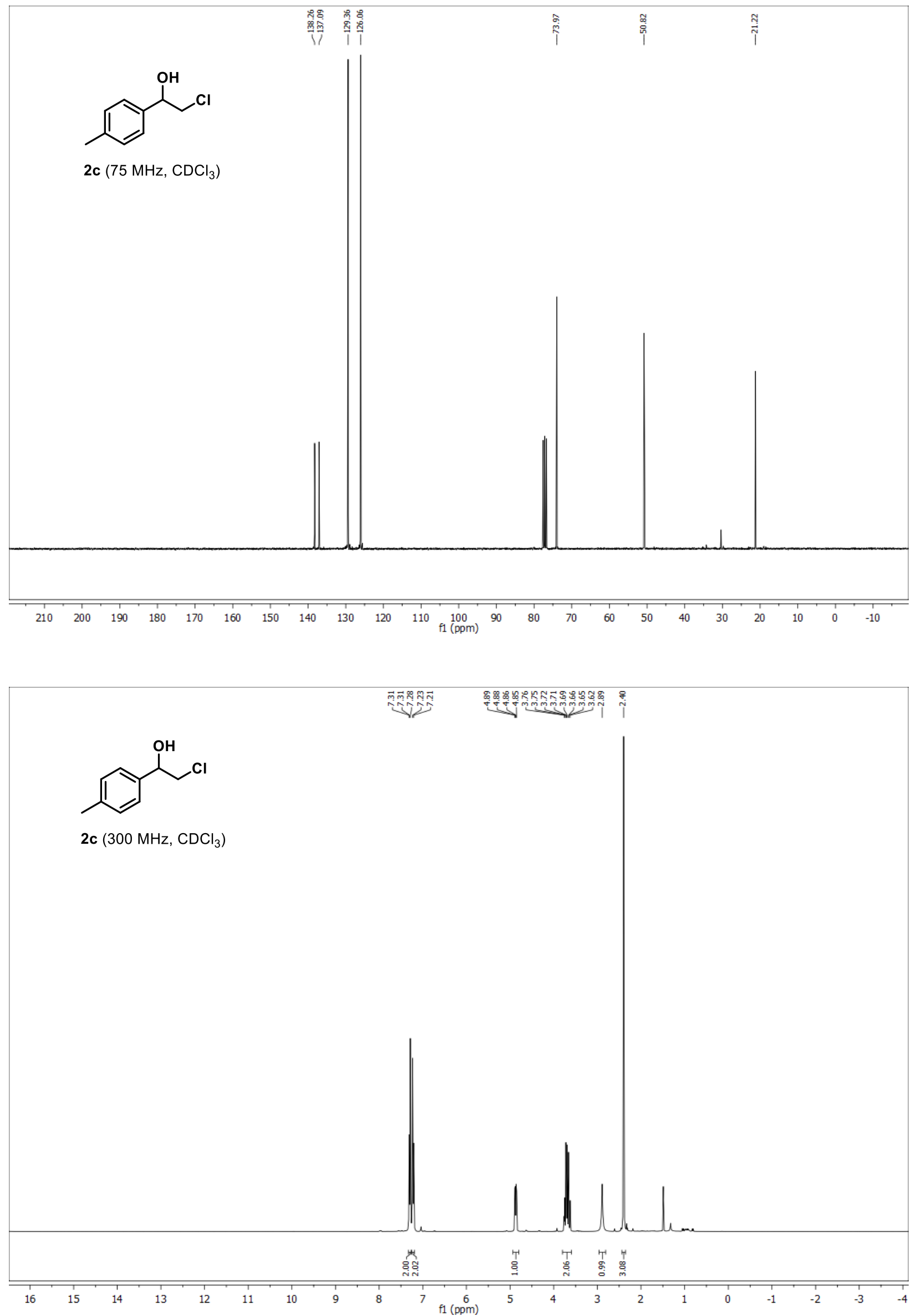

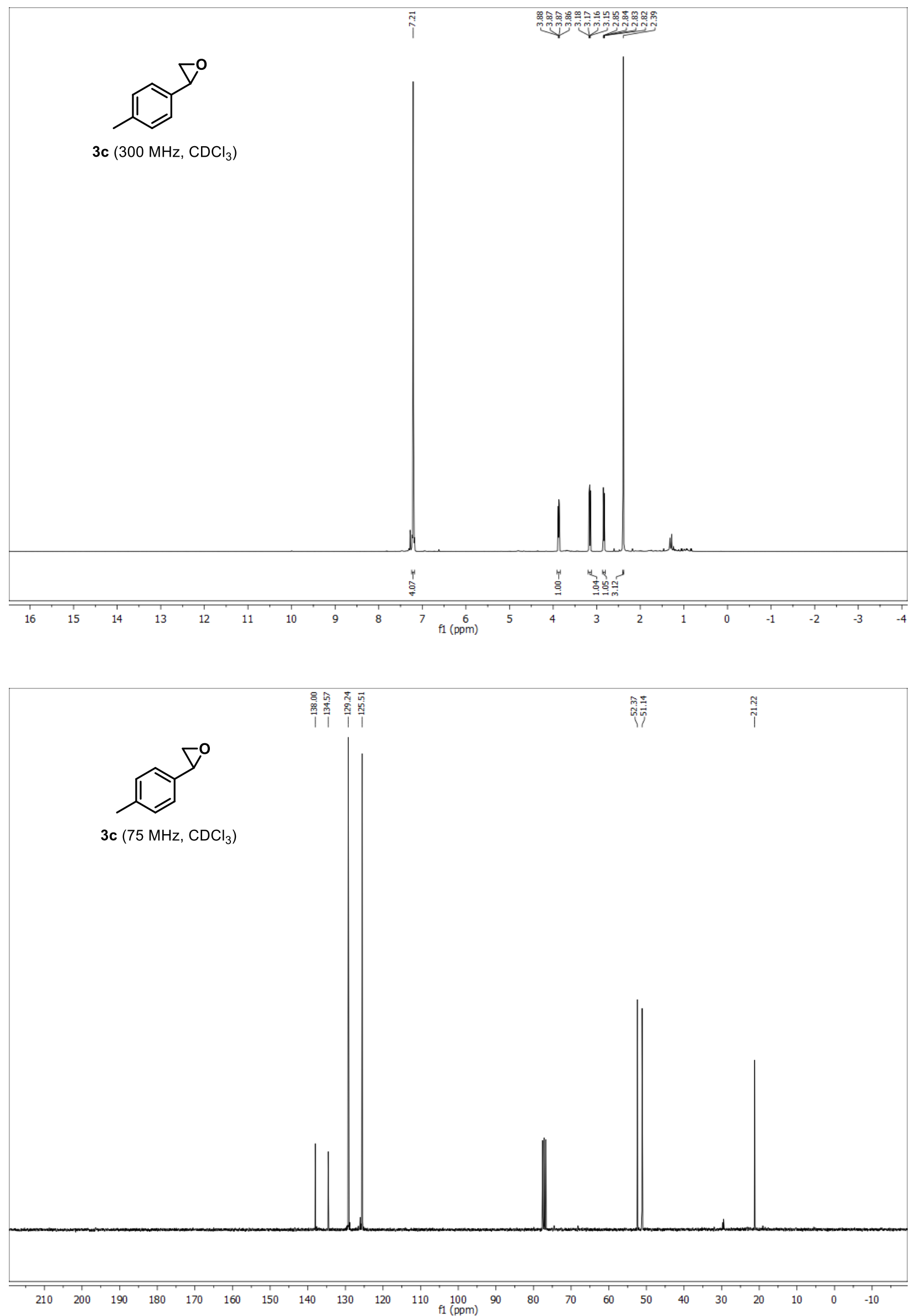

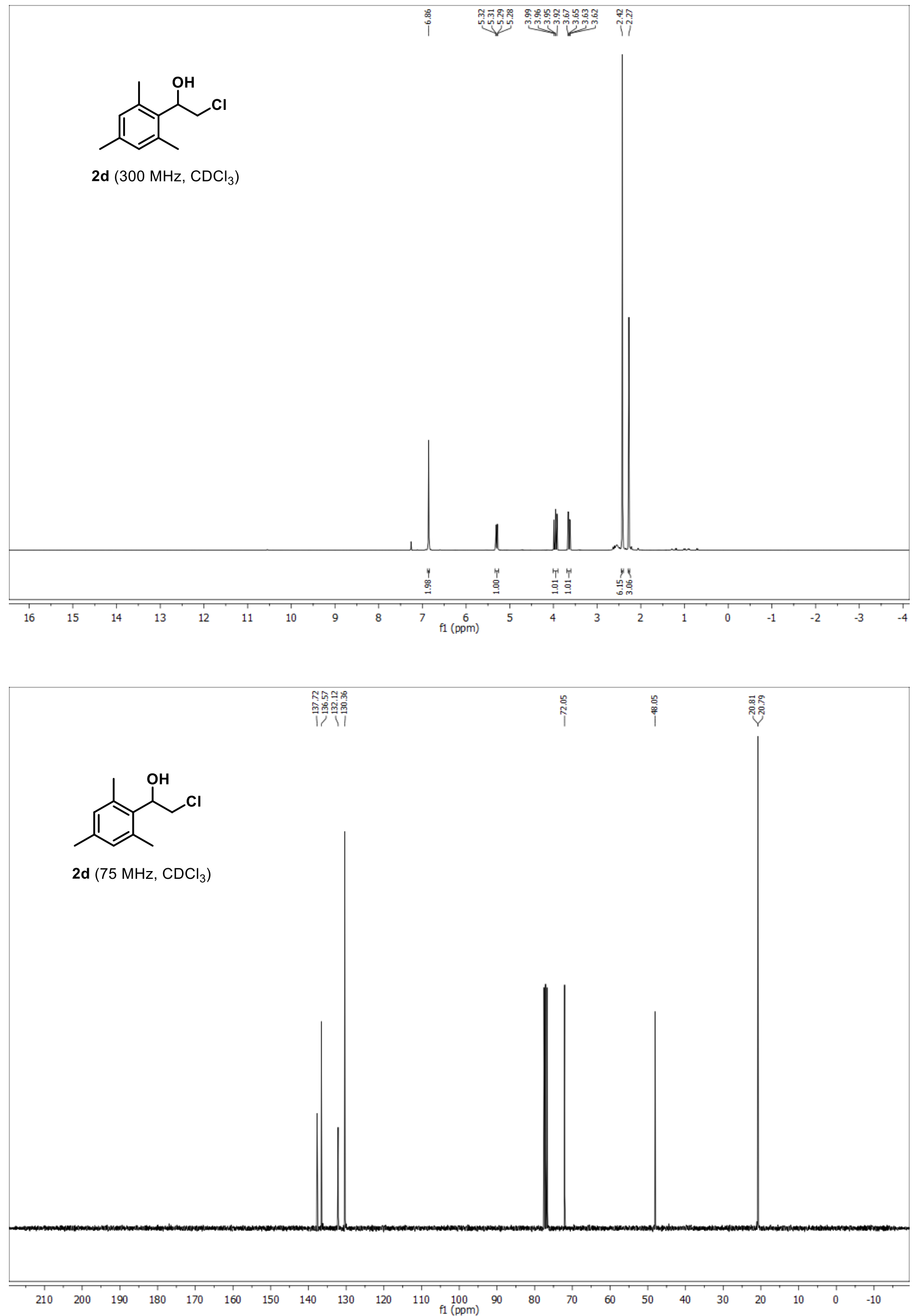

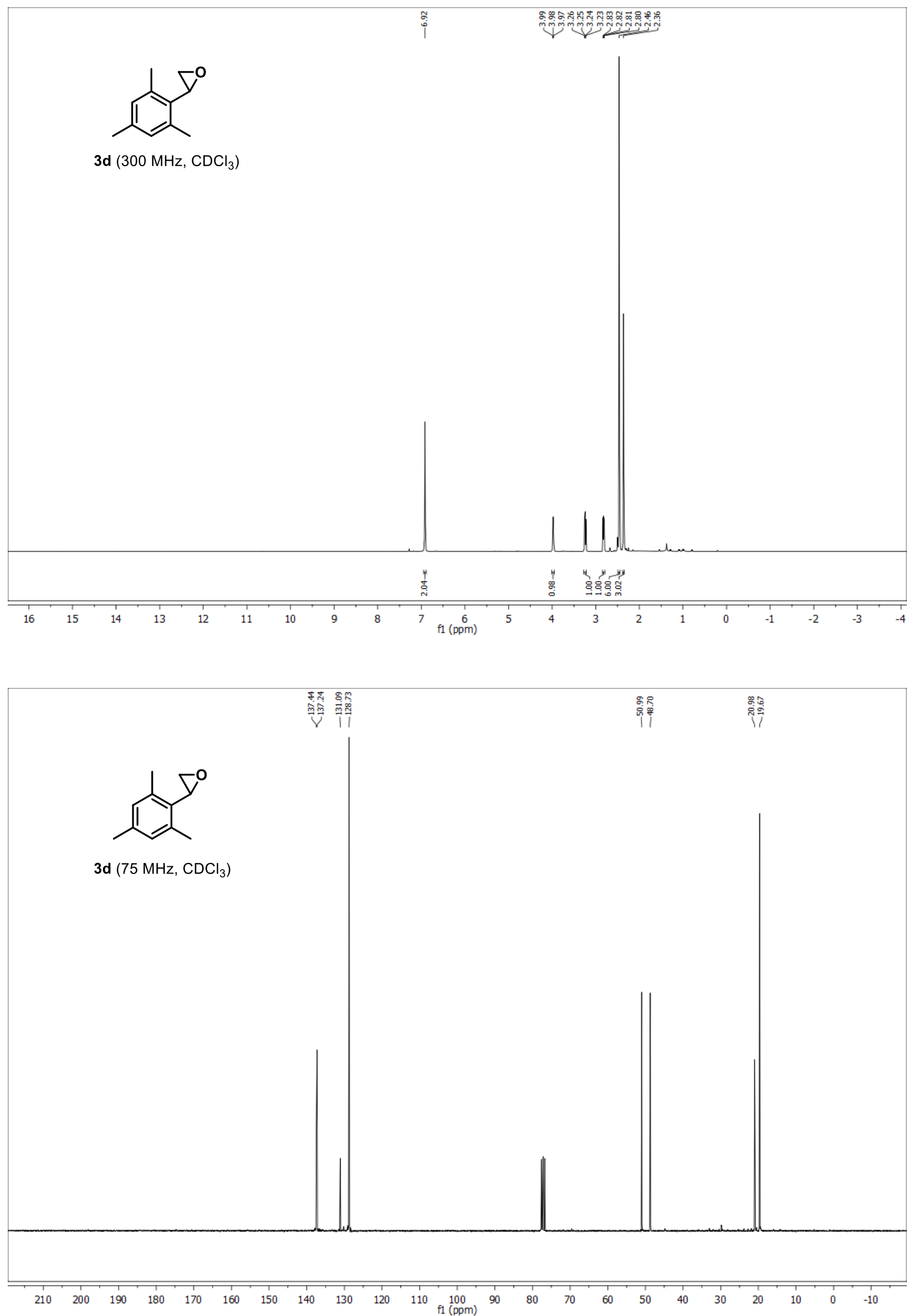

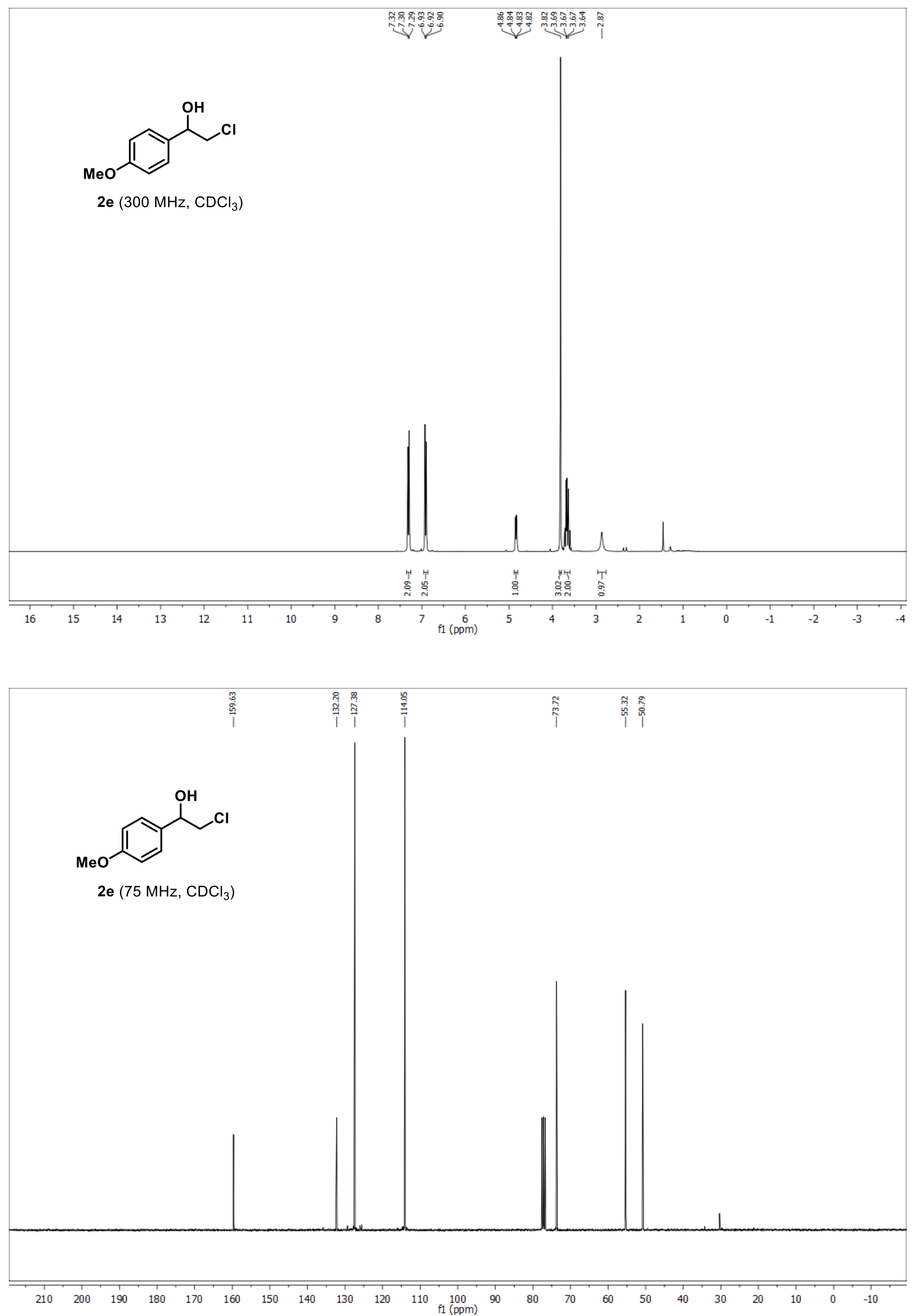

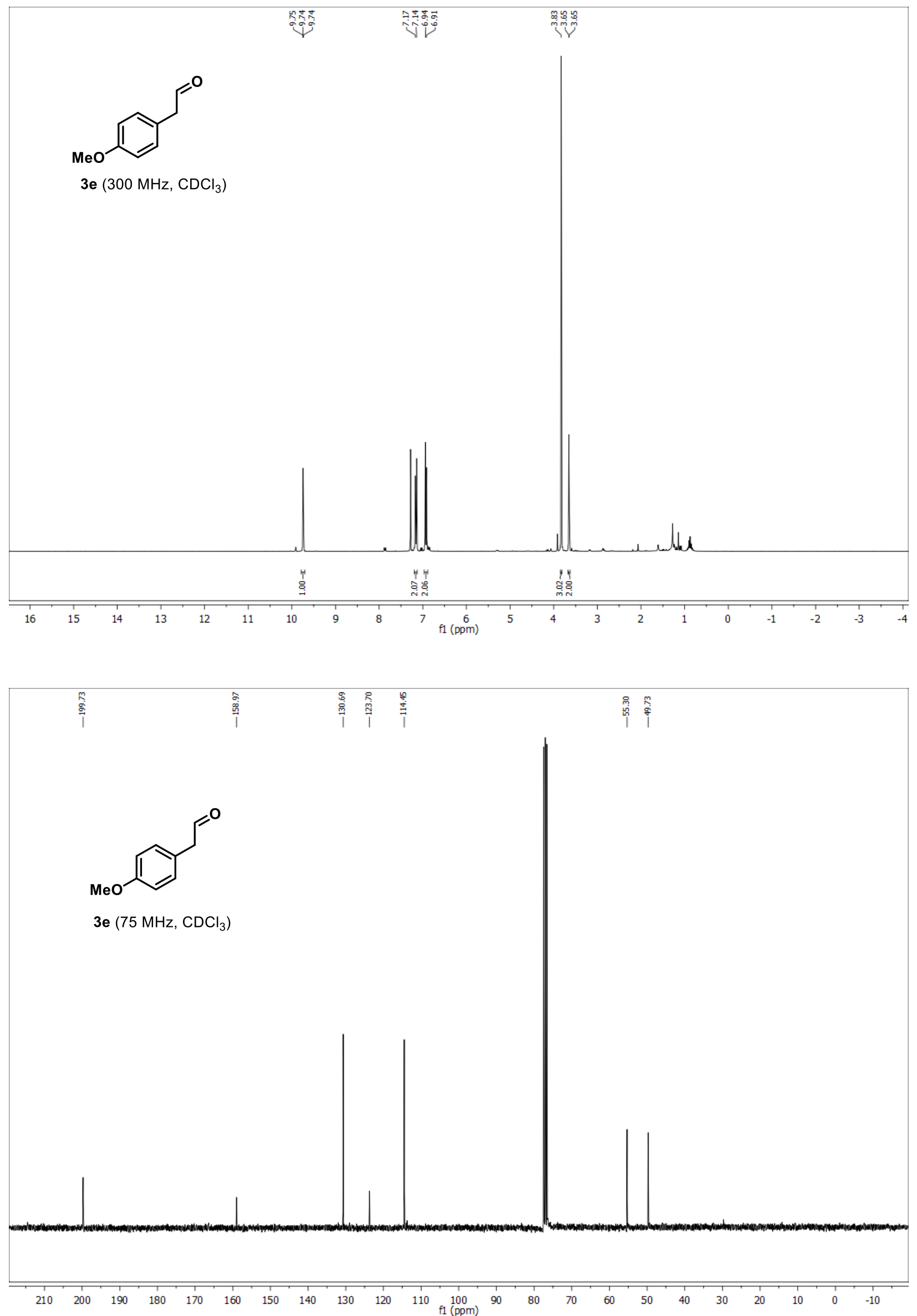

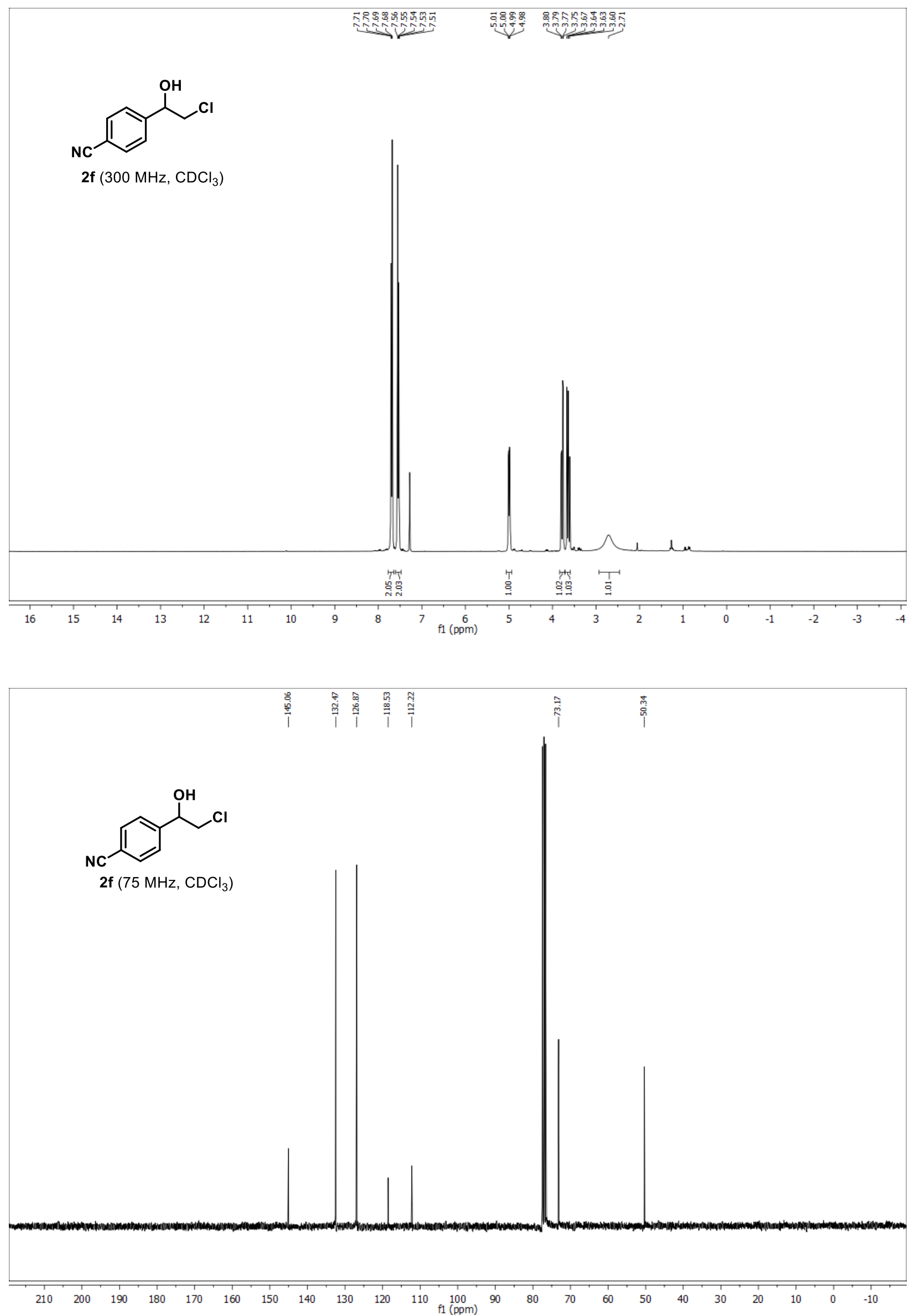

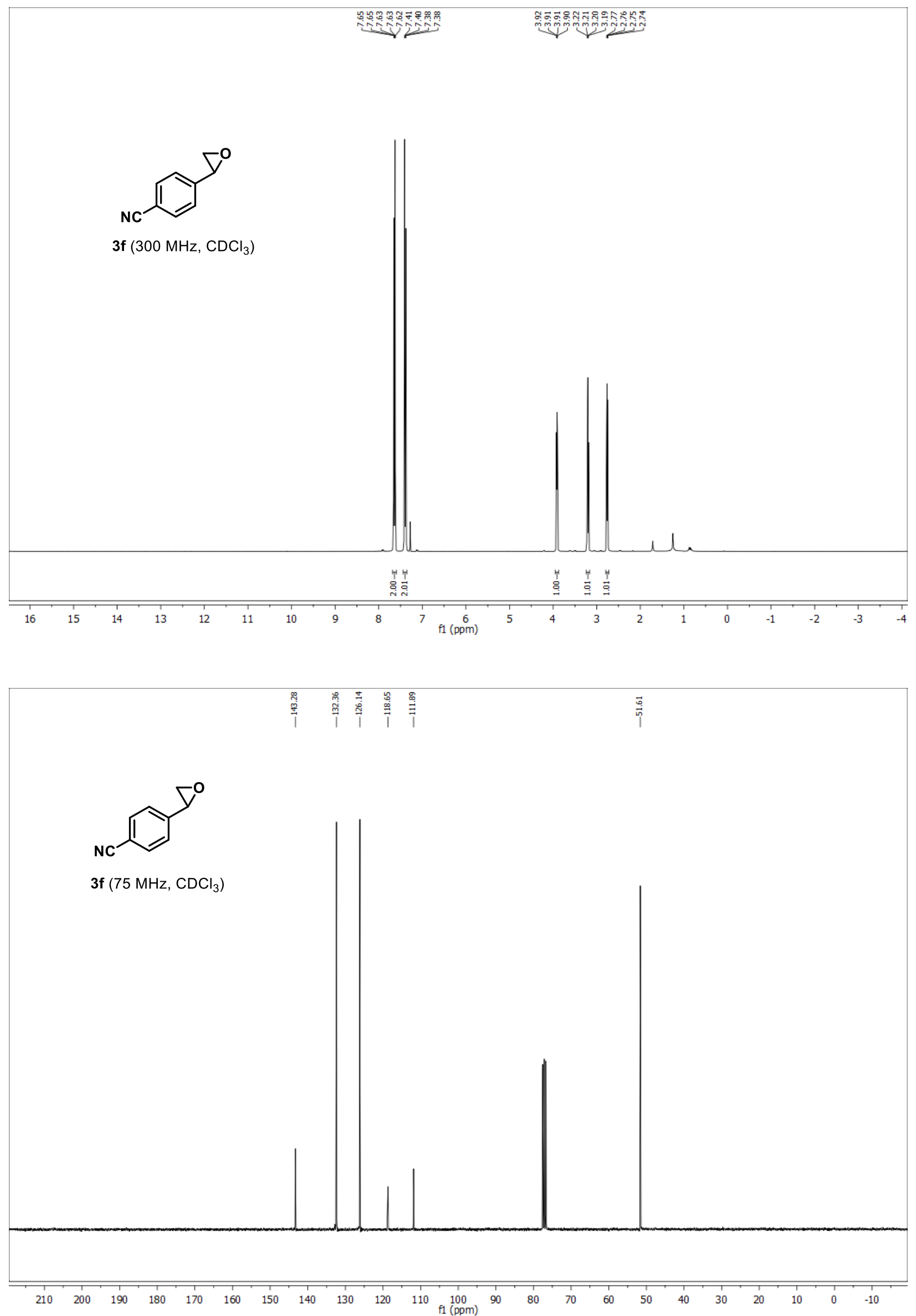

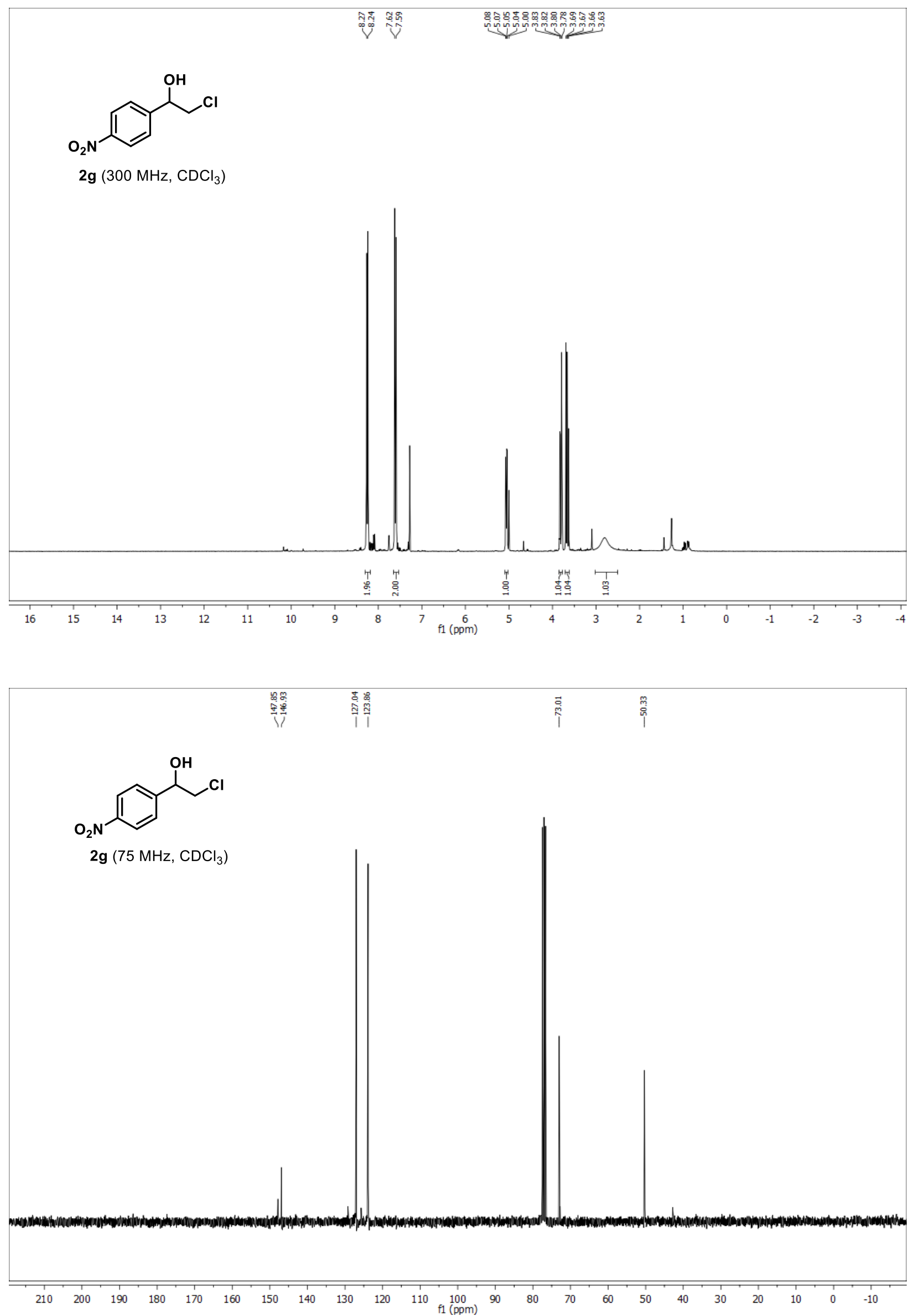

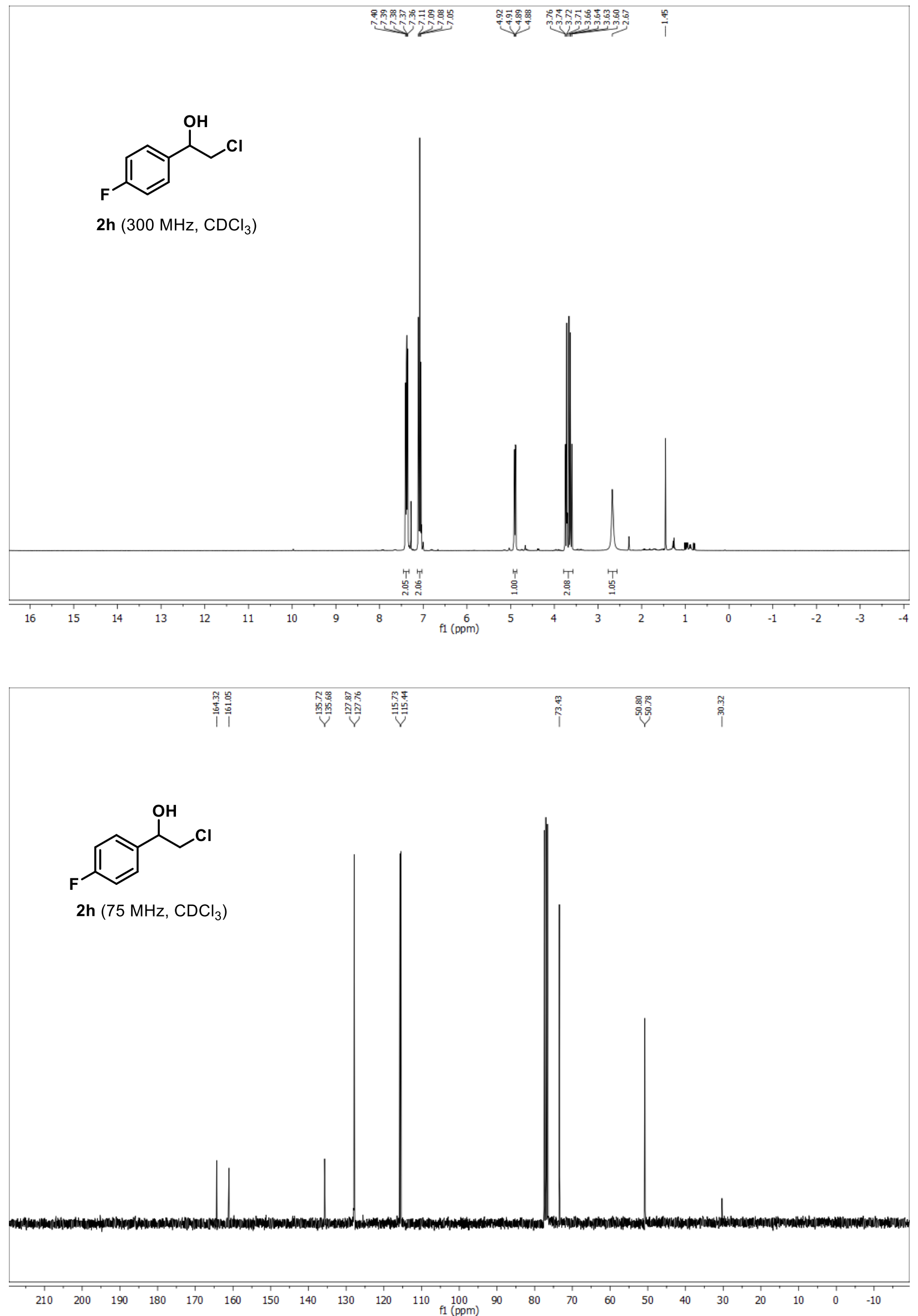

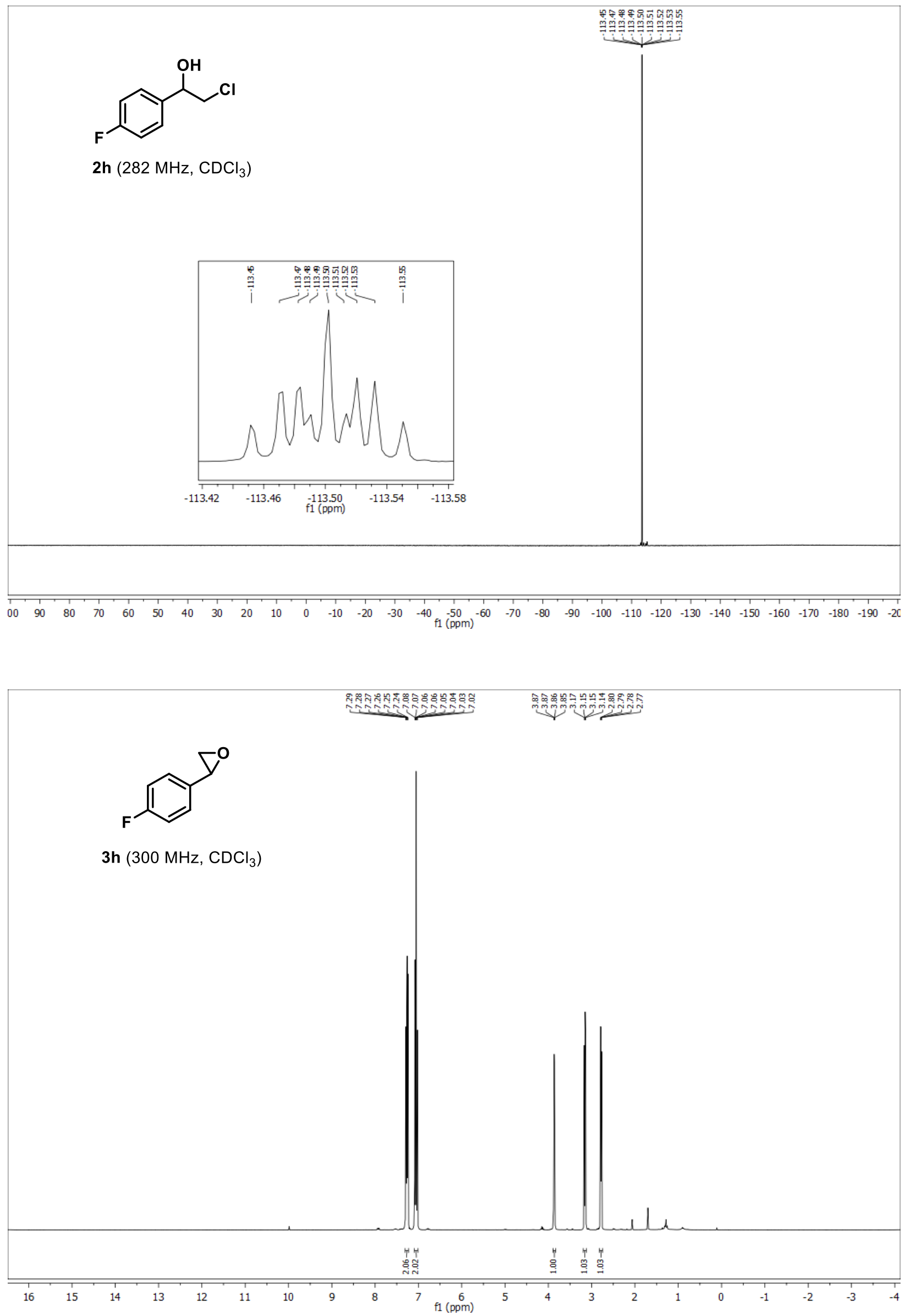

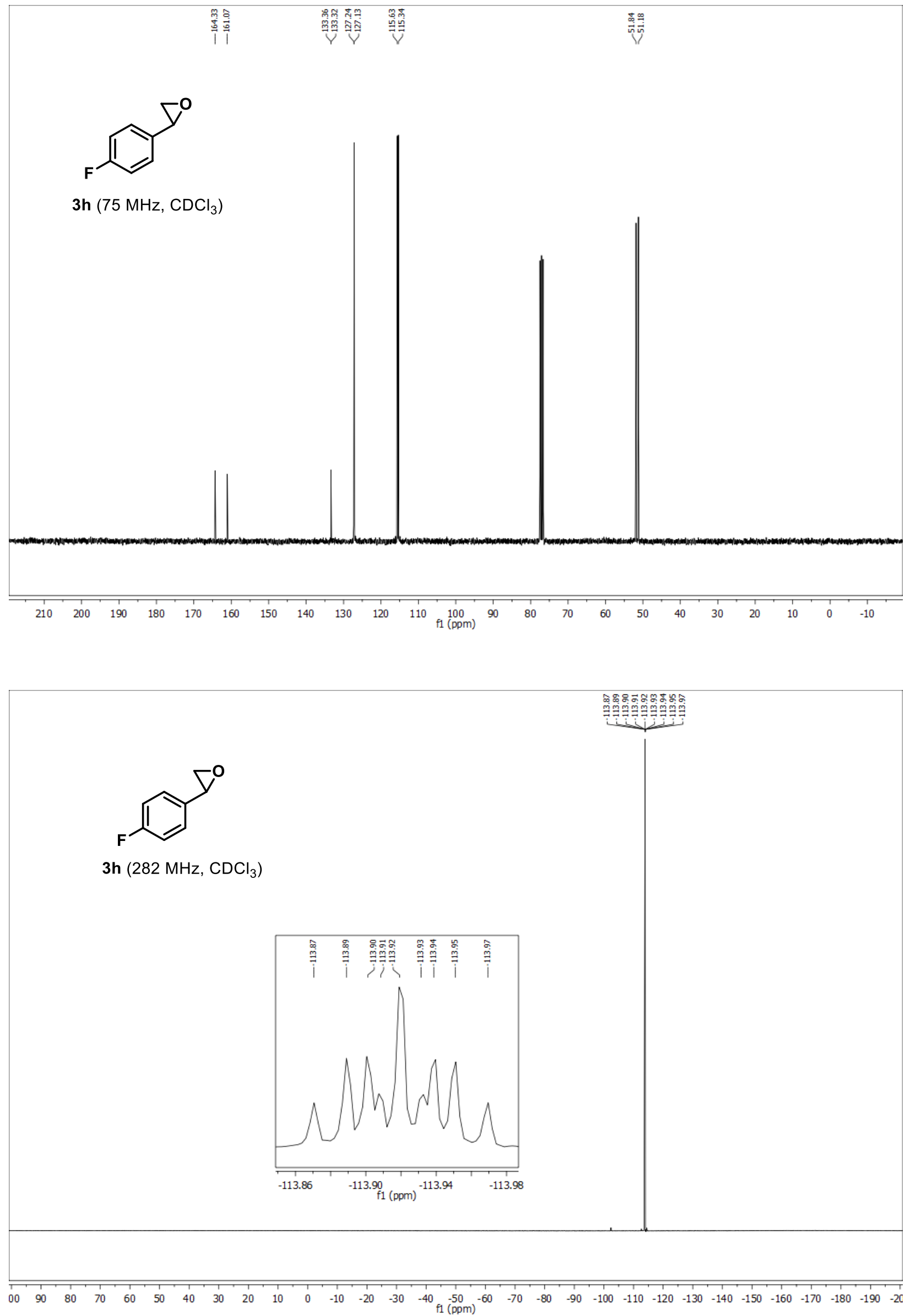

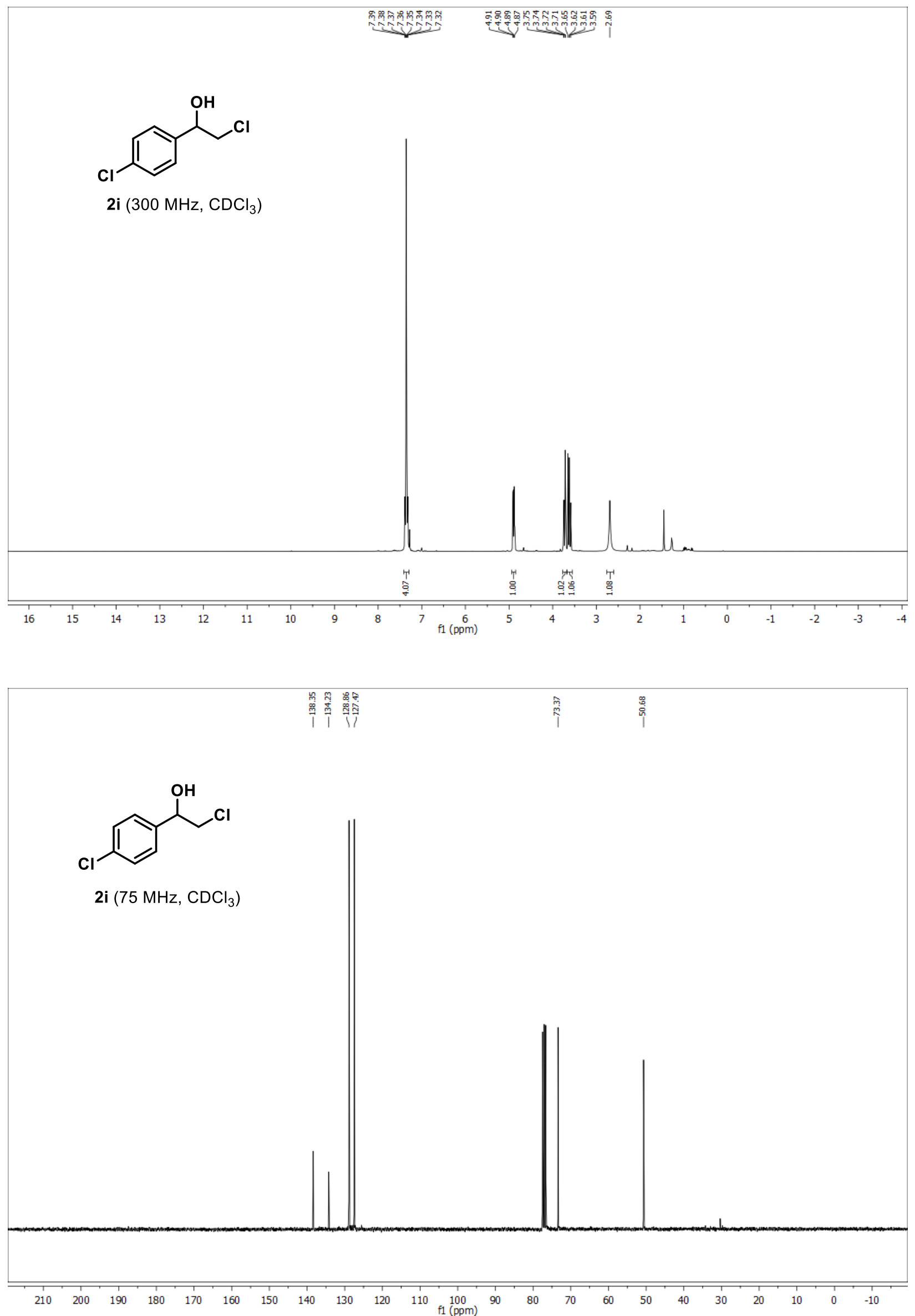
S34
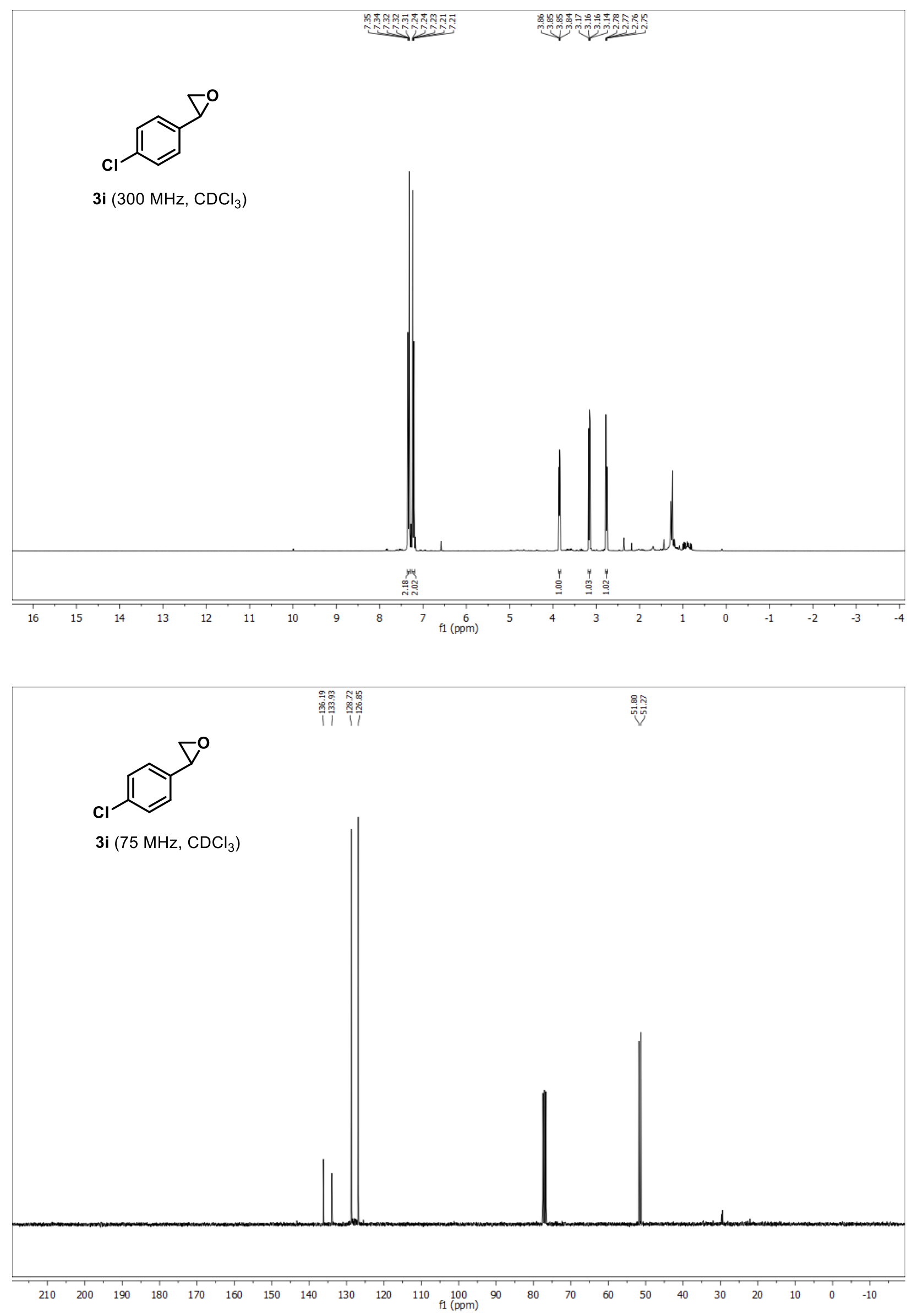

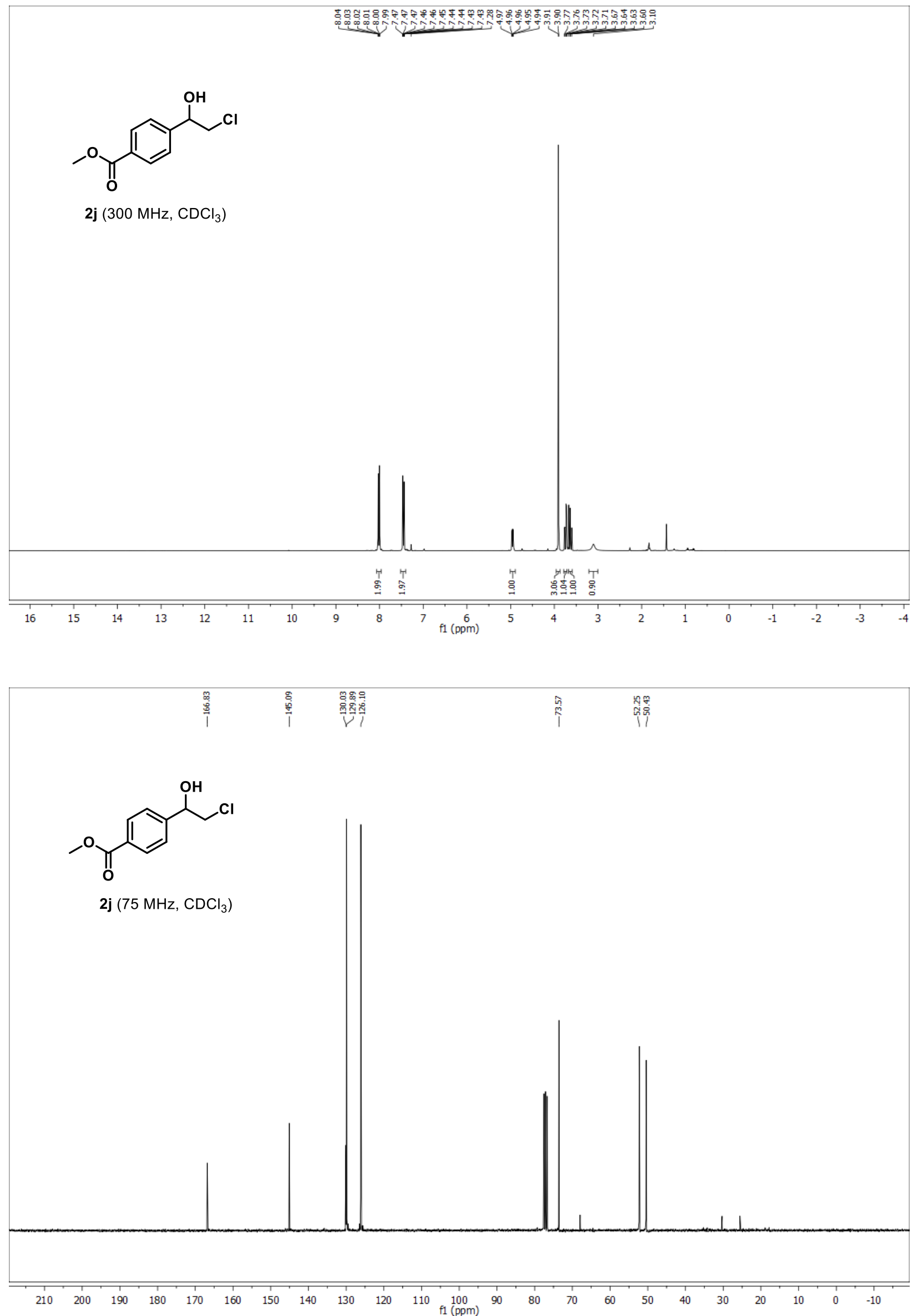

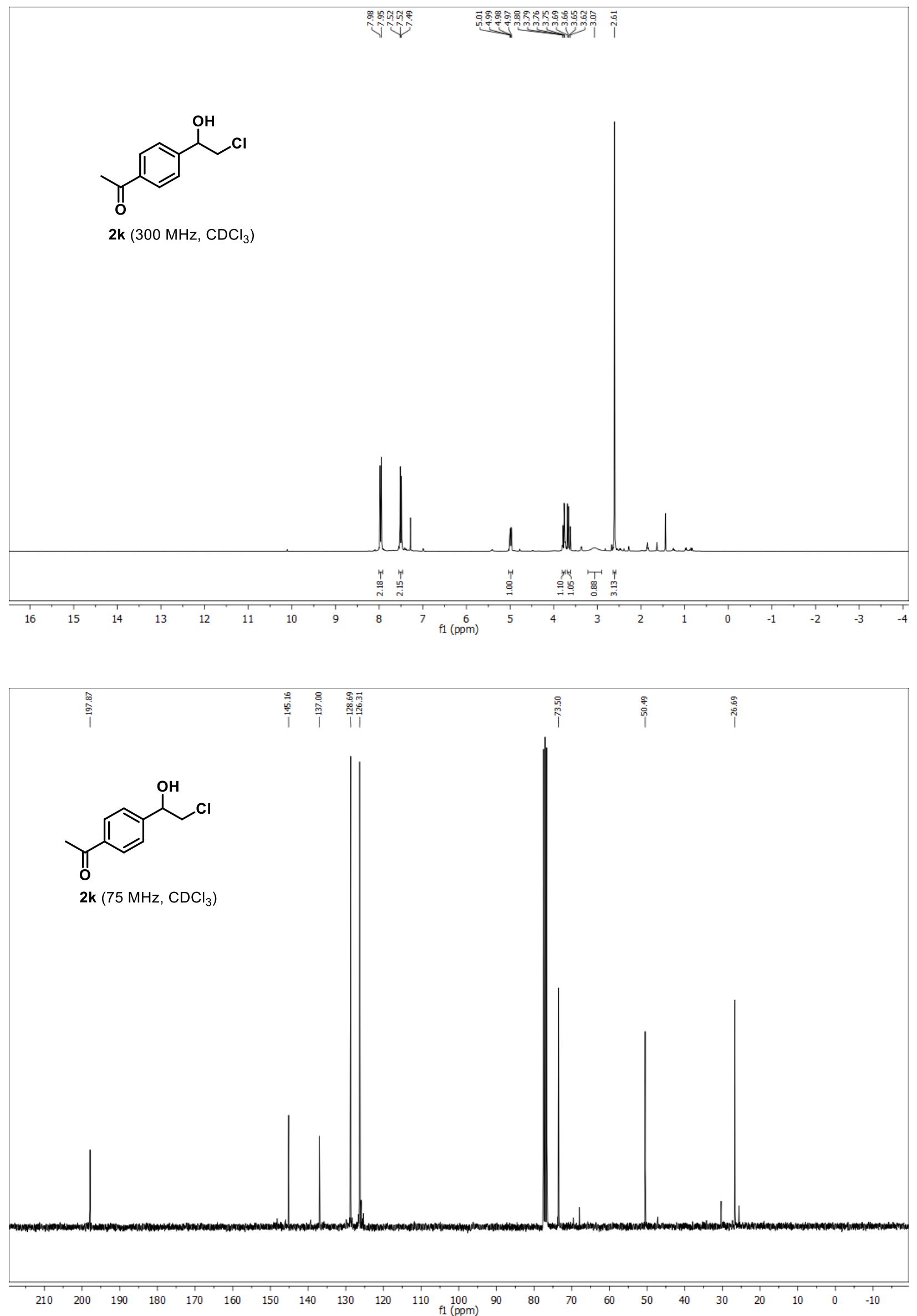

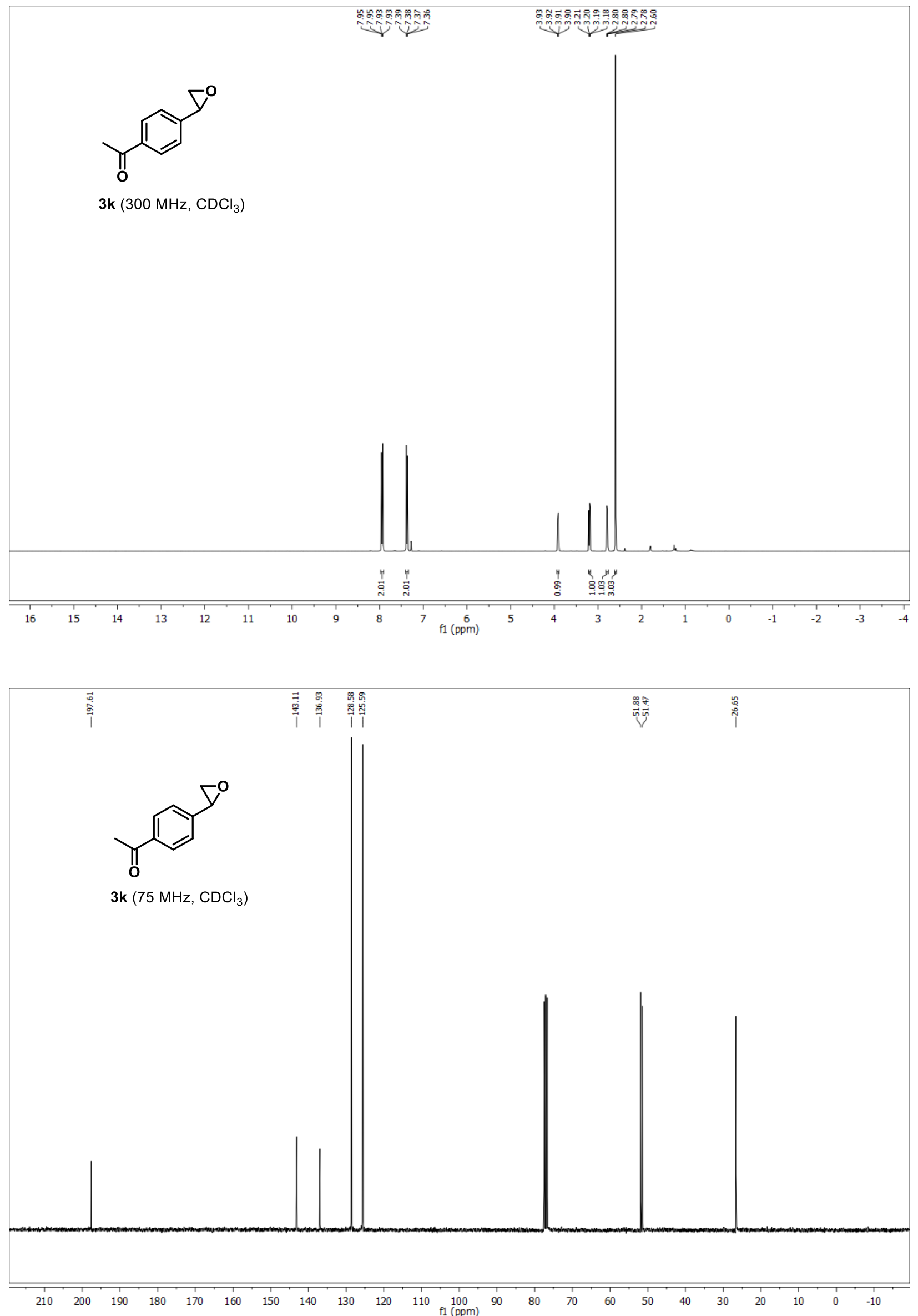

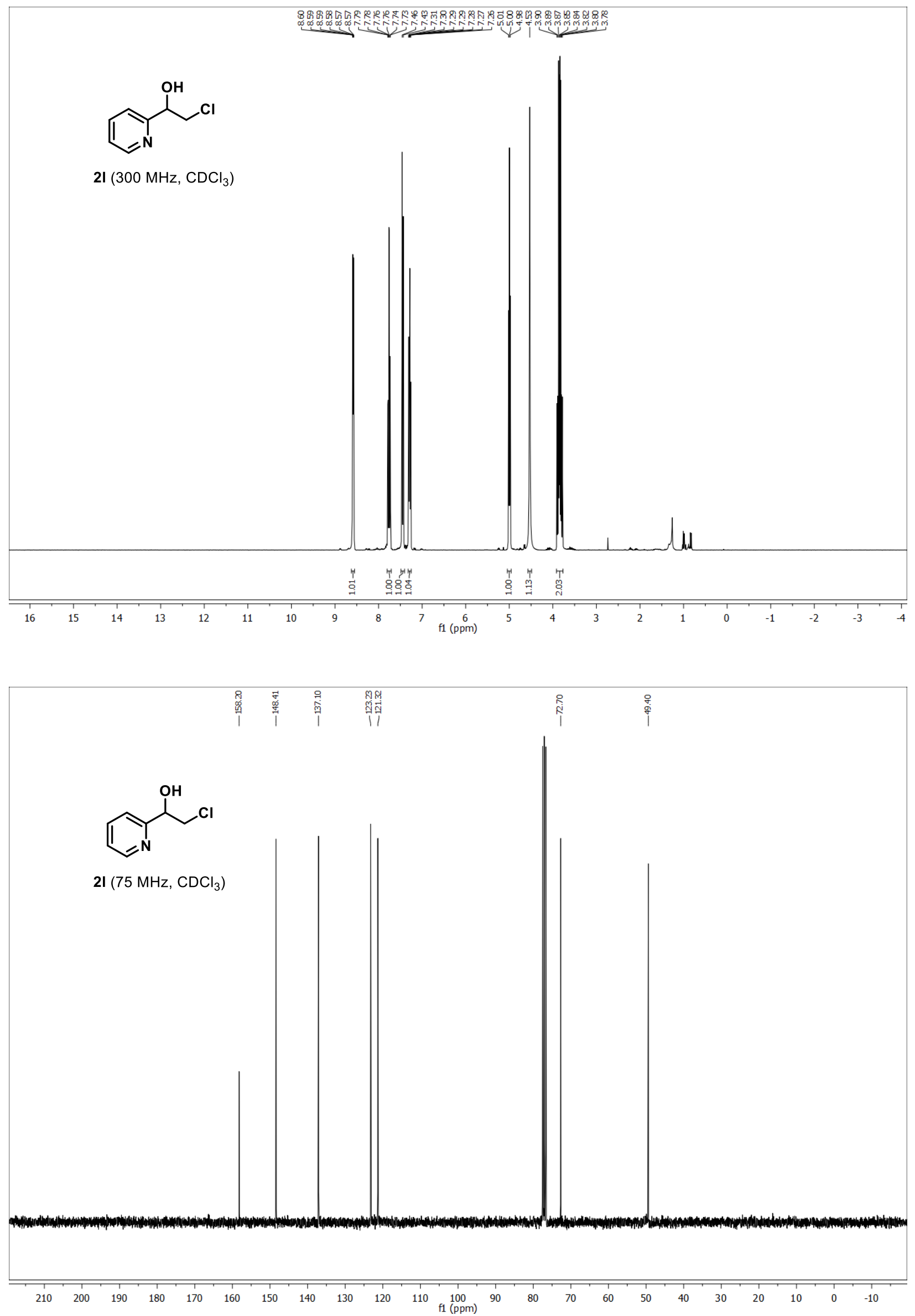

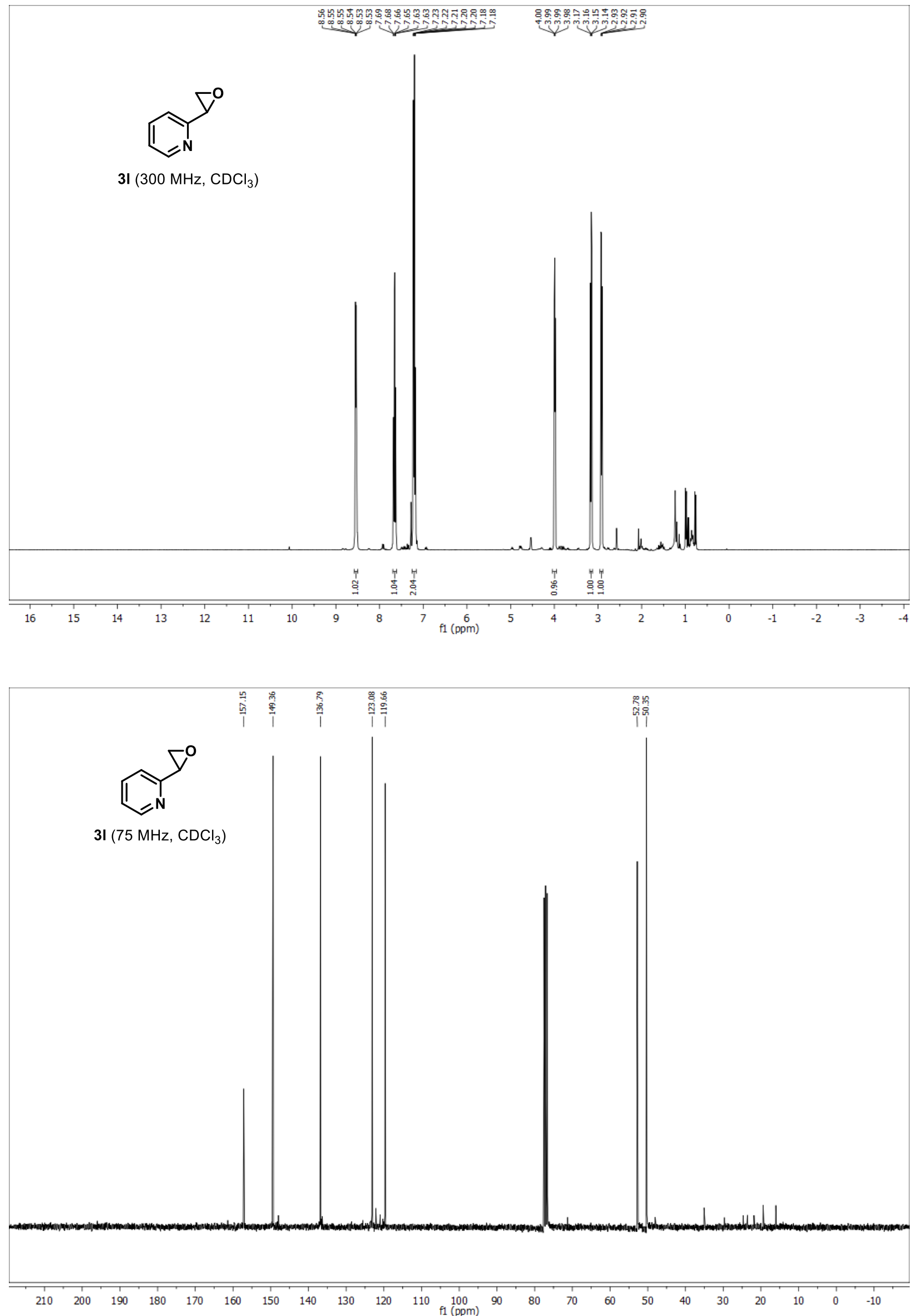

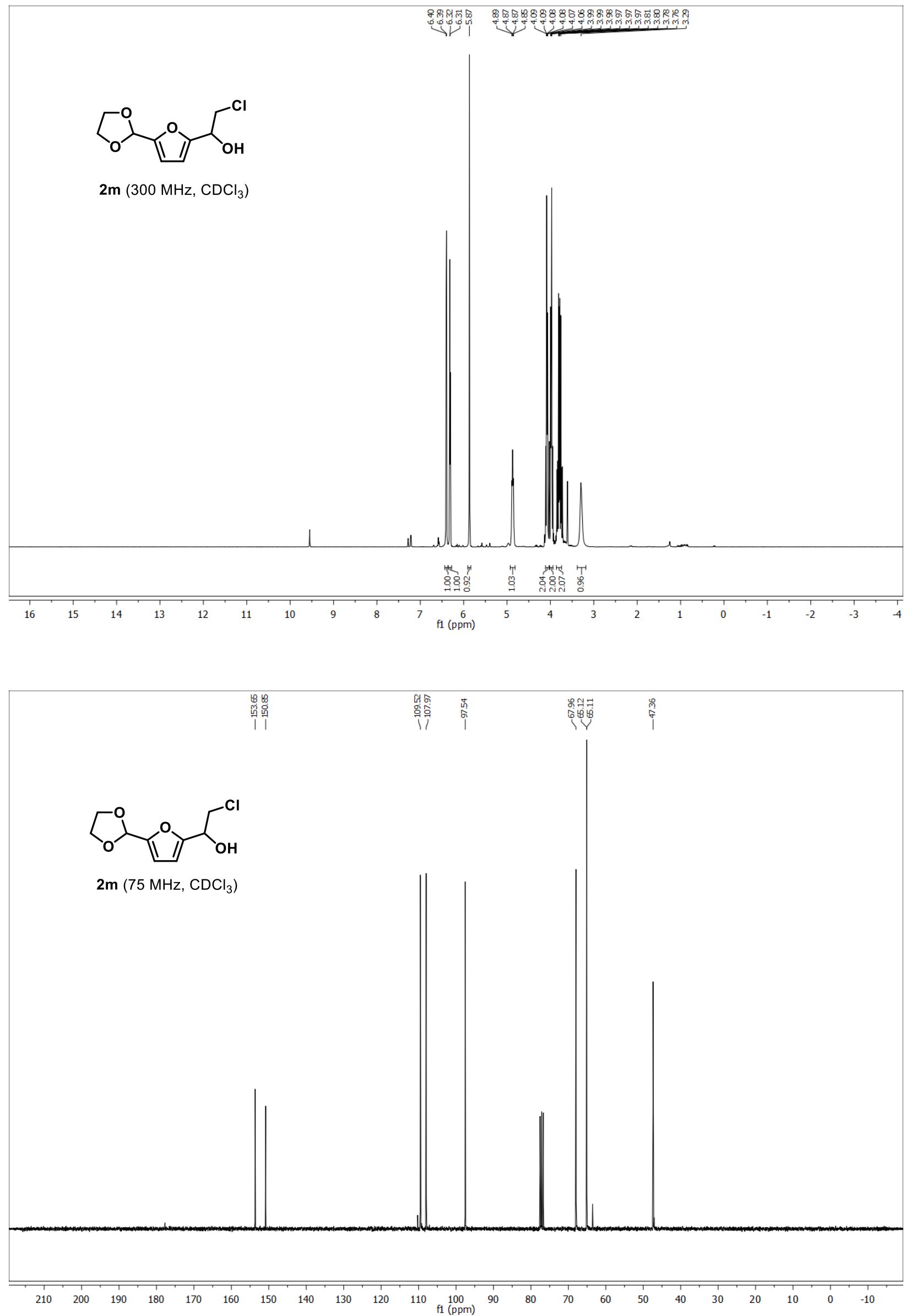

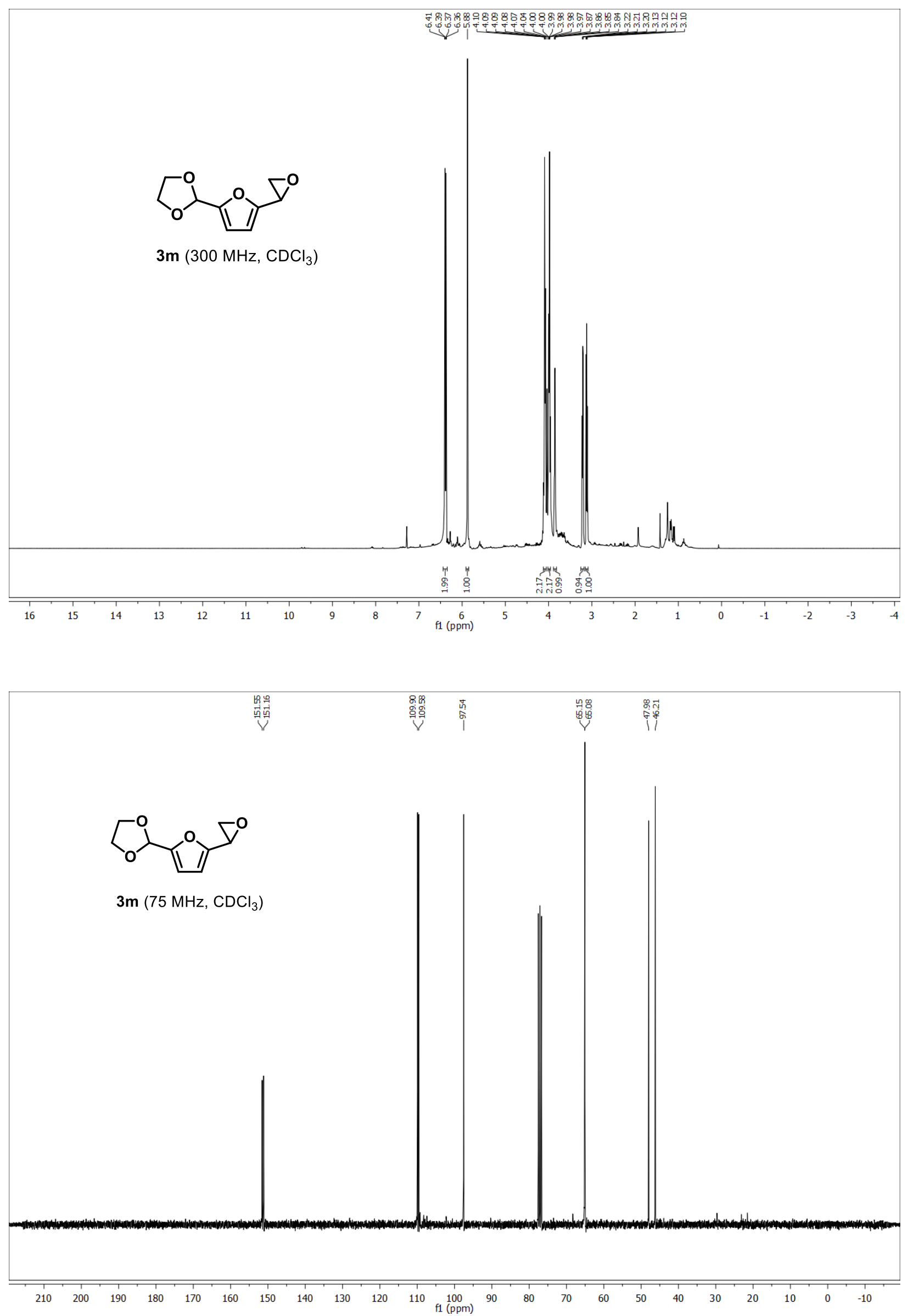

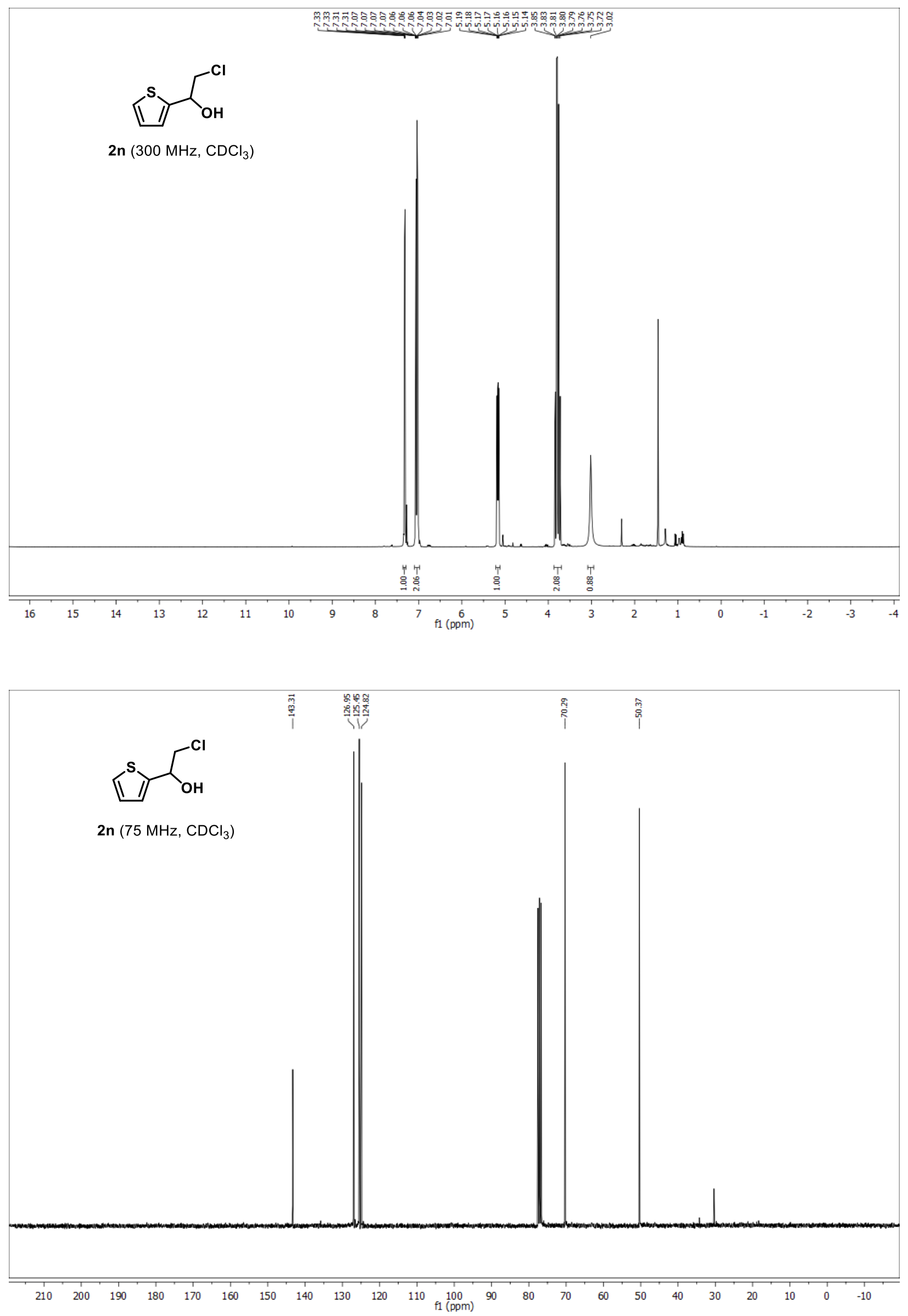

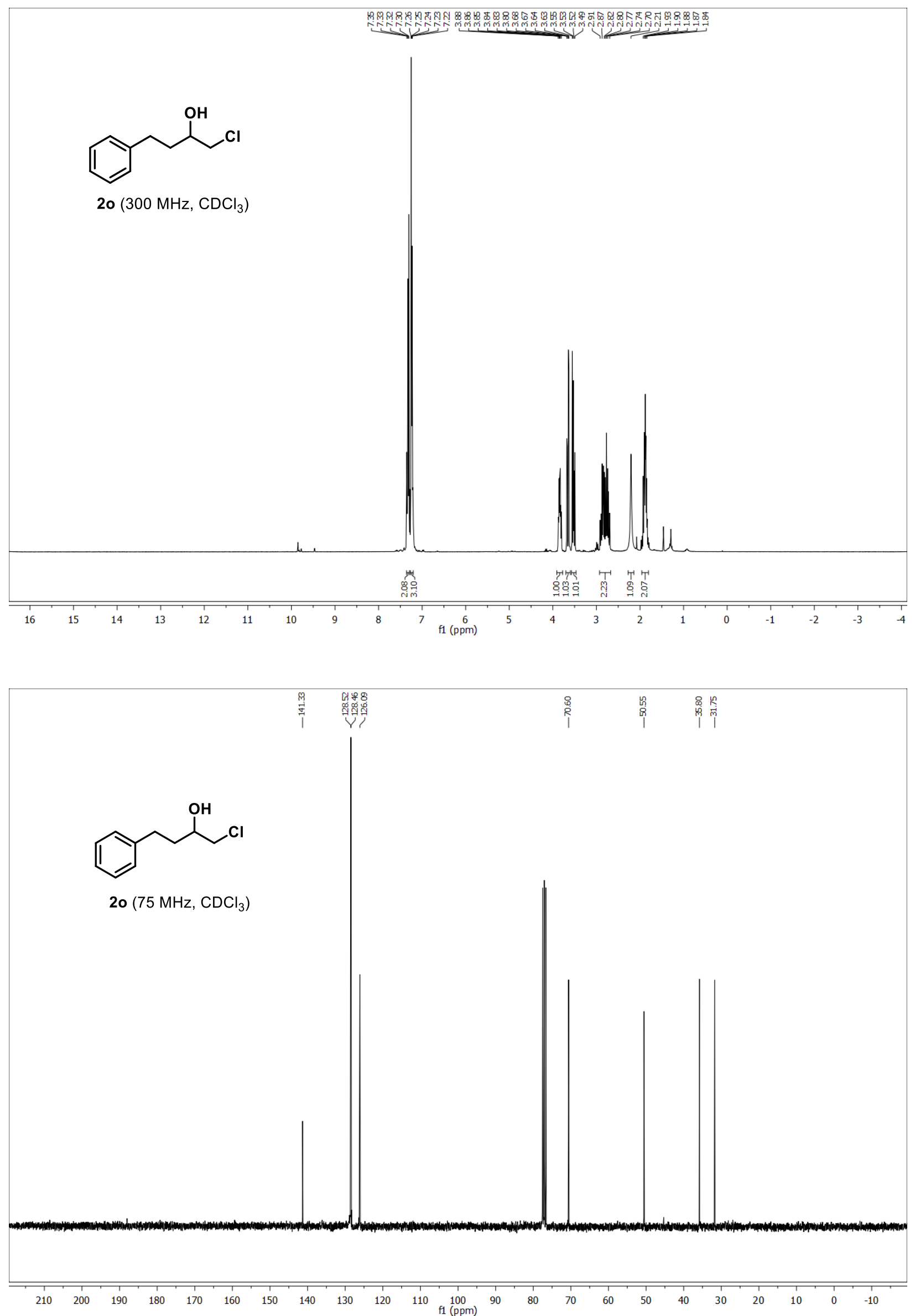

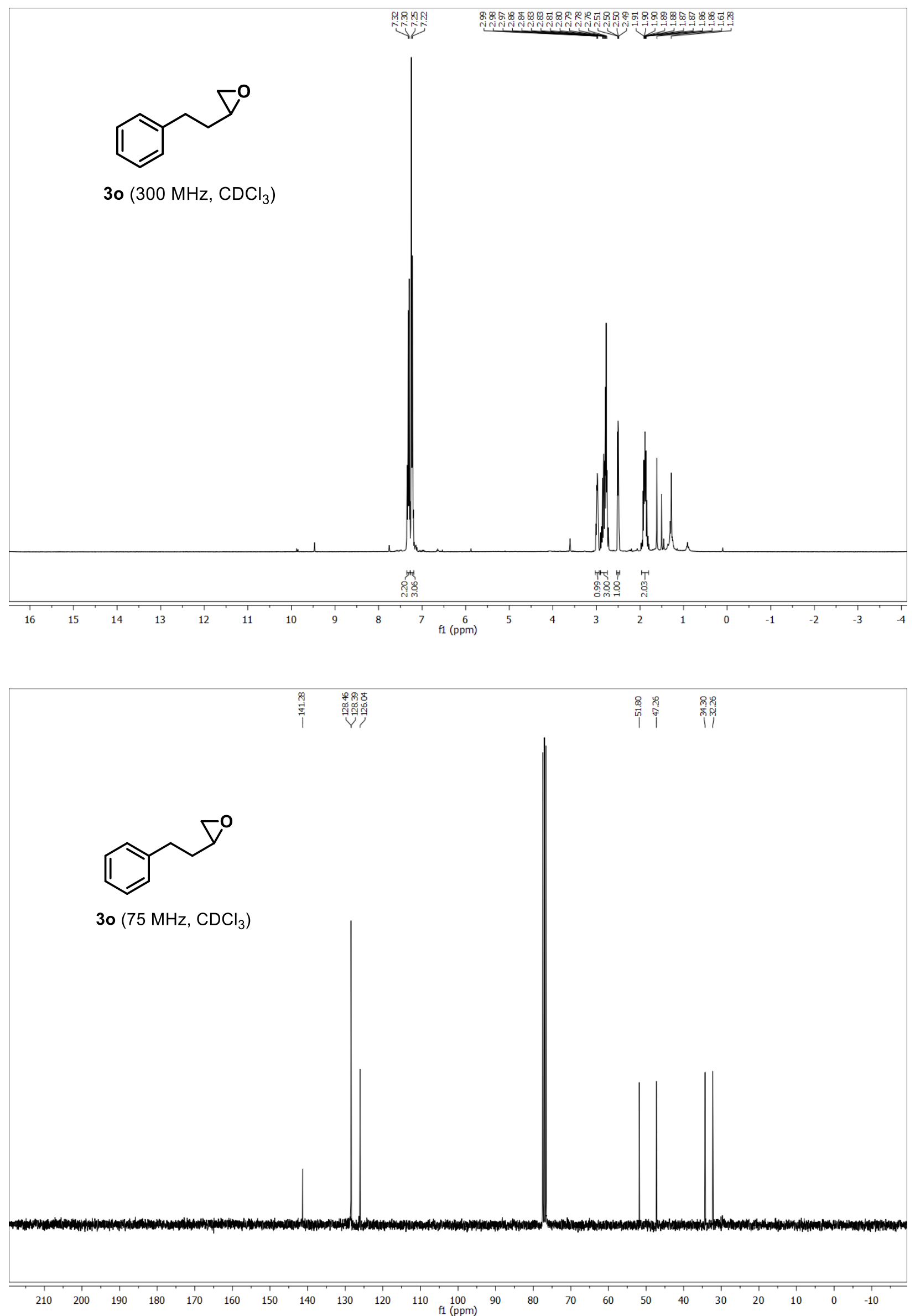
S45
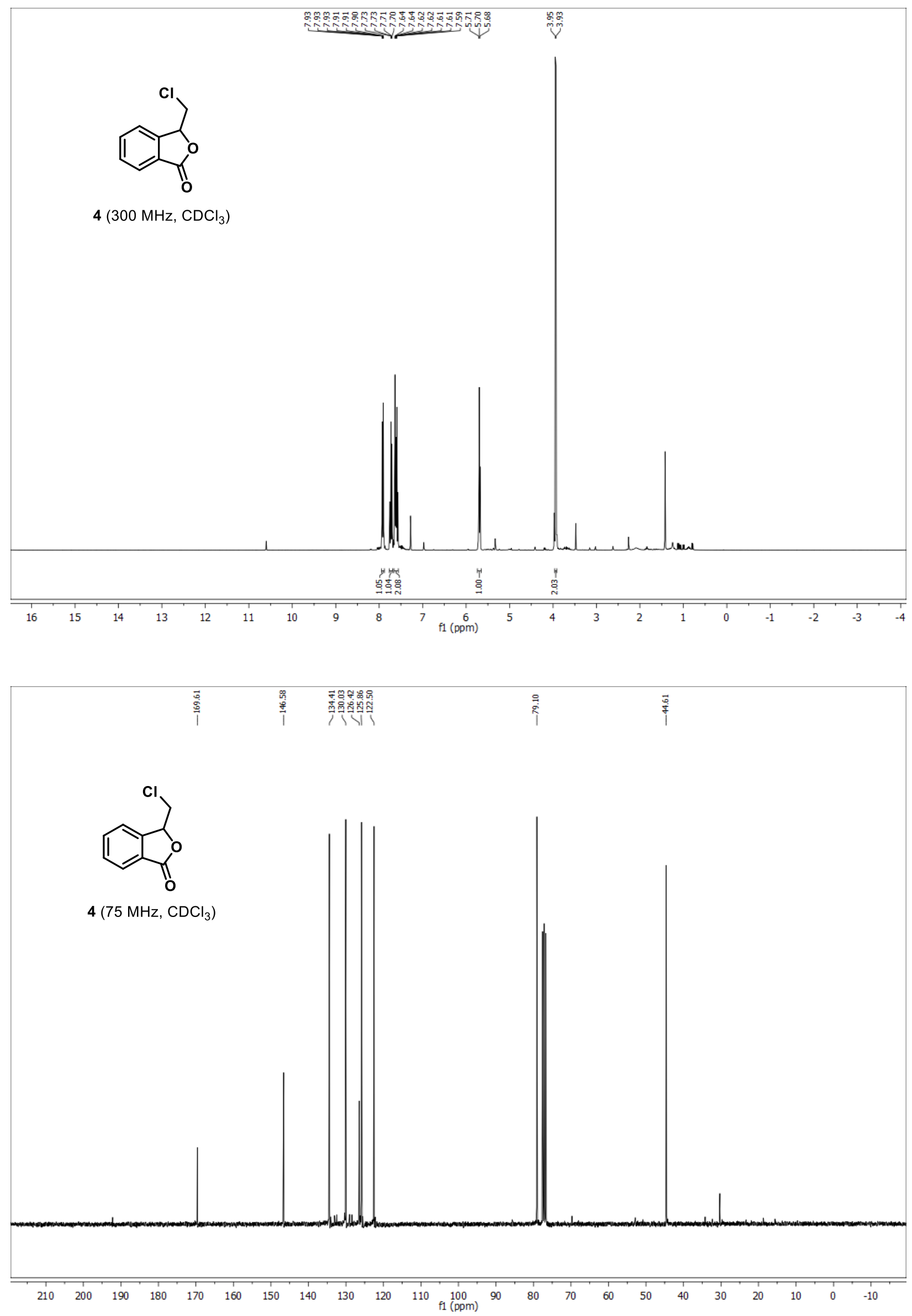

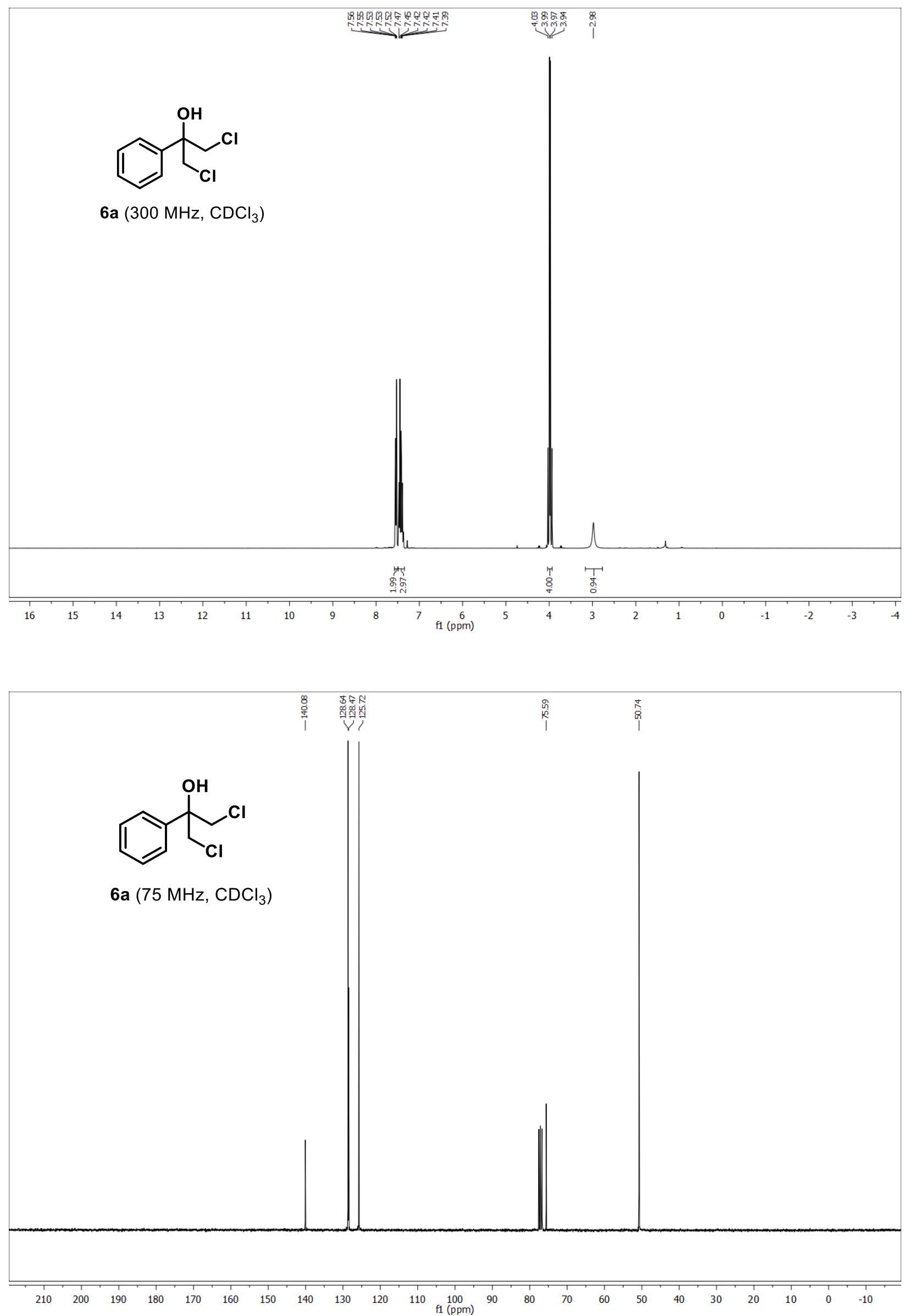

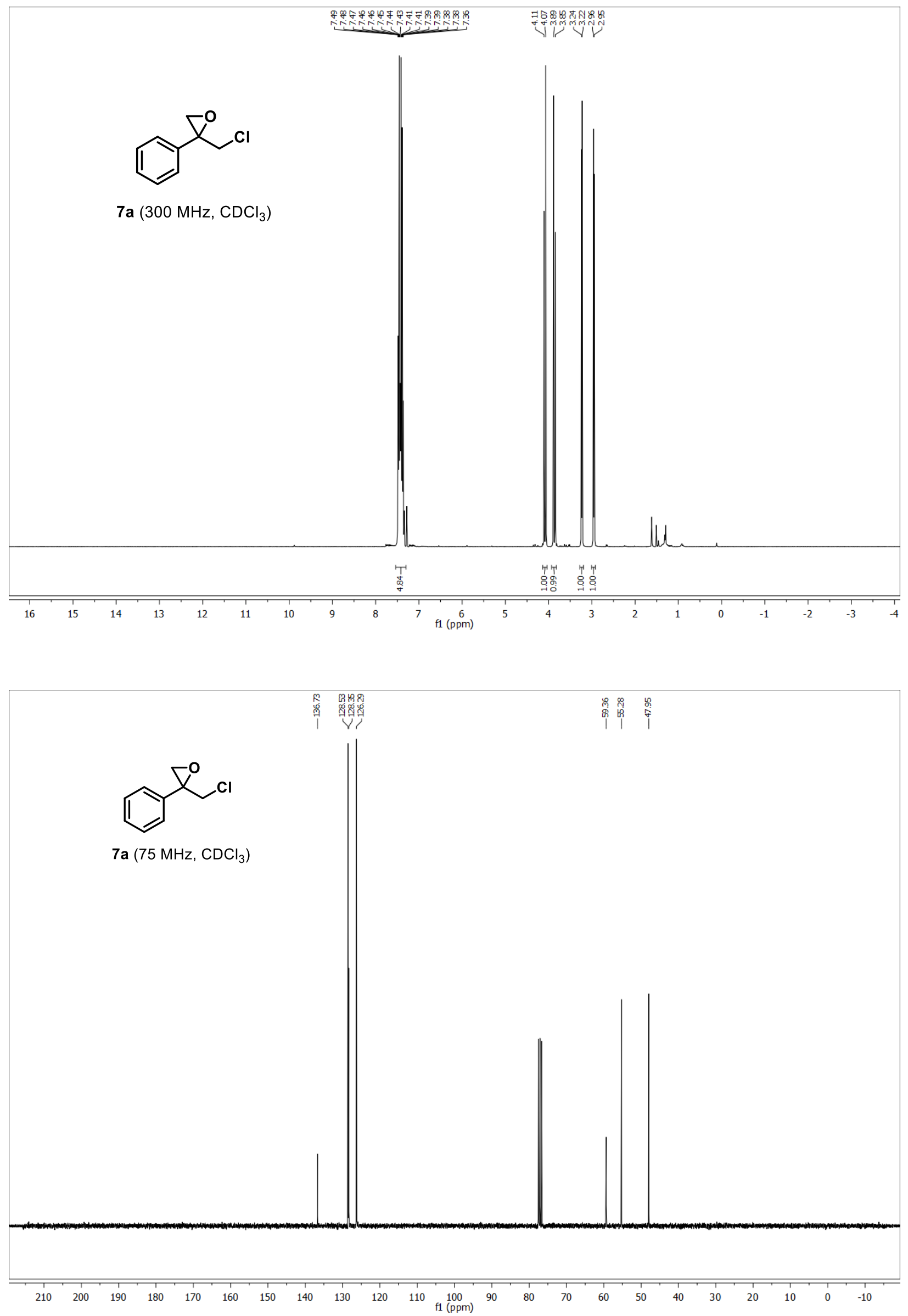

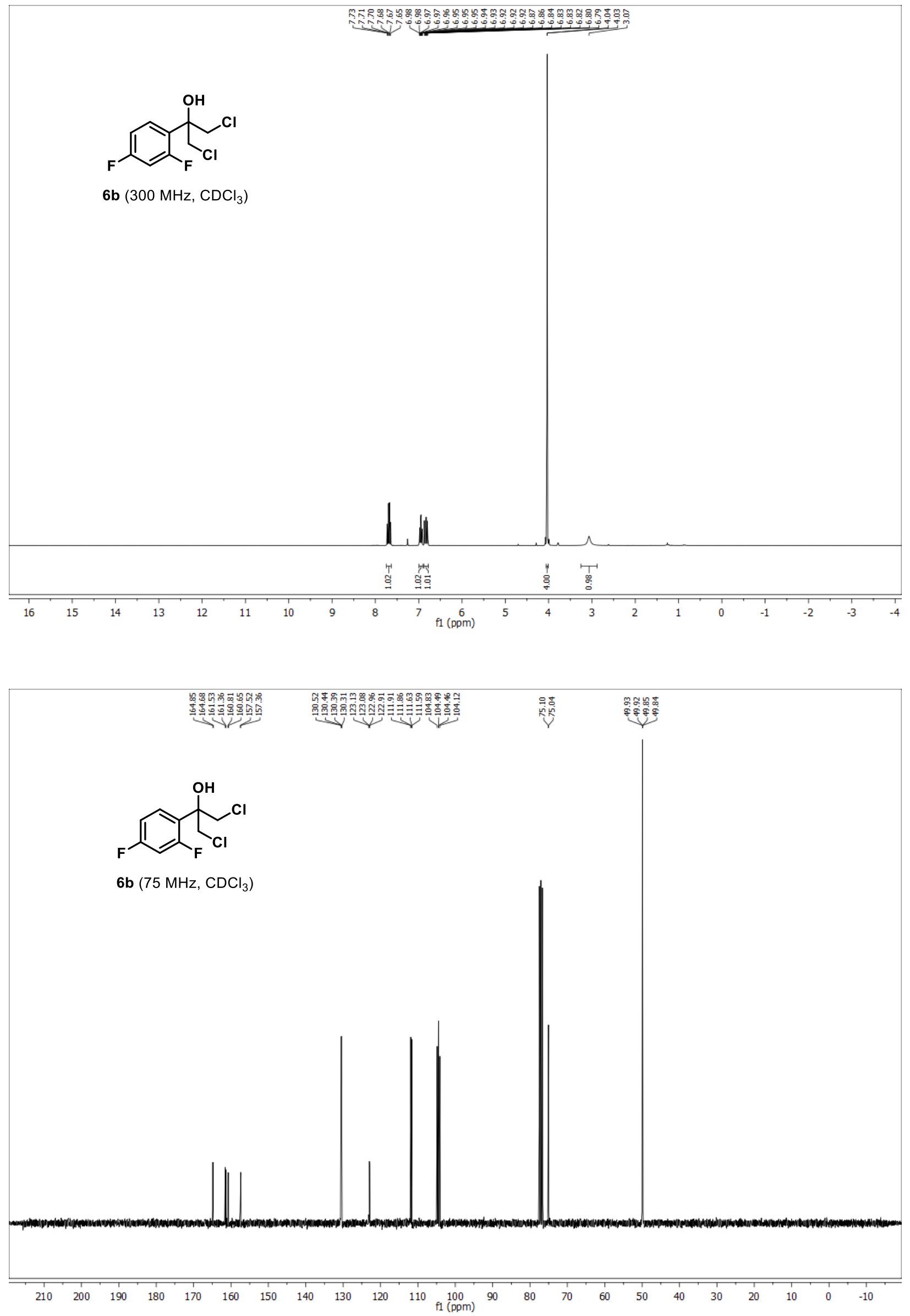

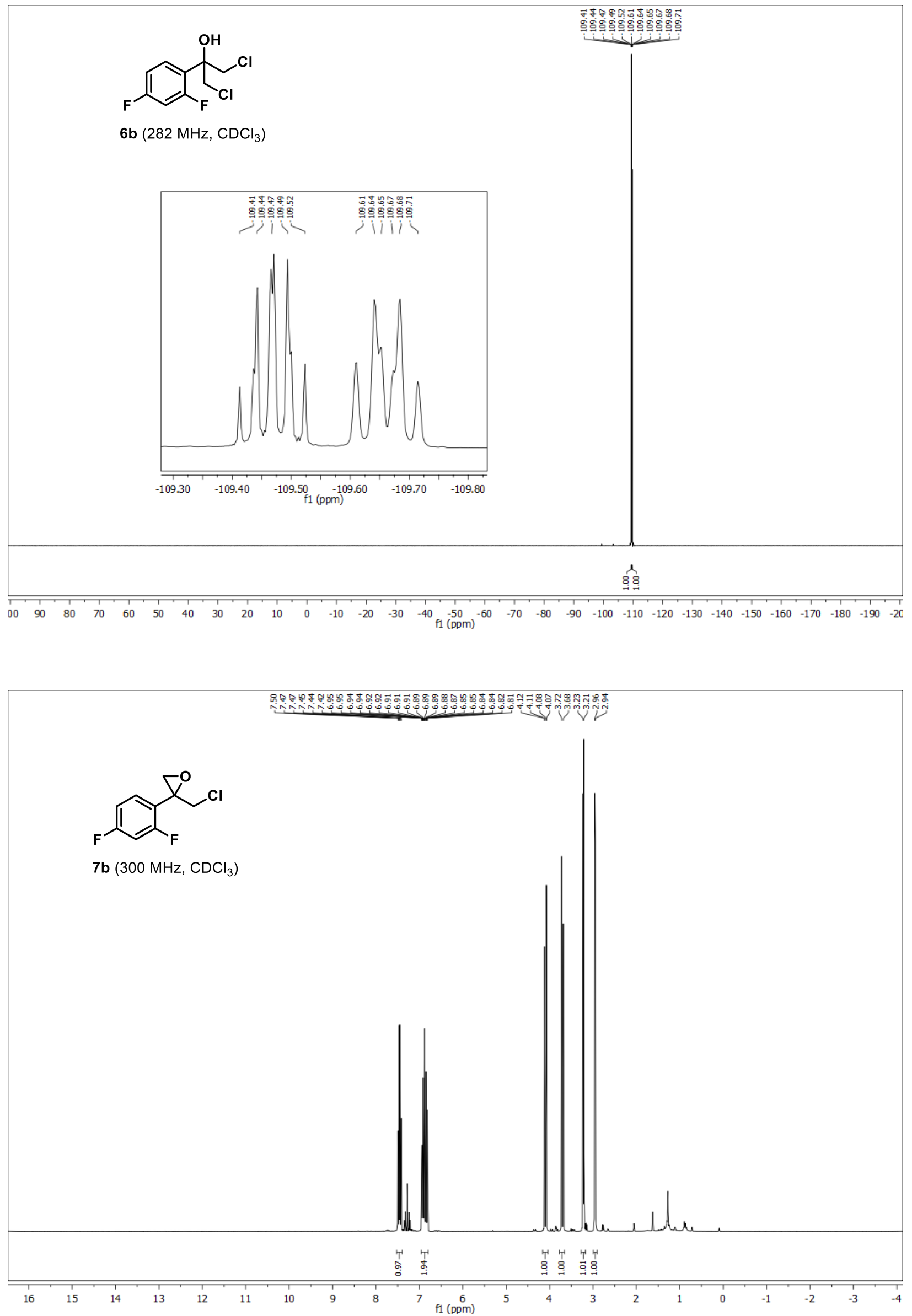

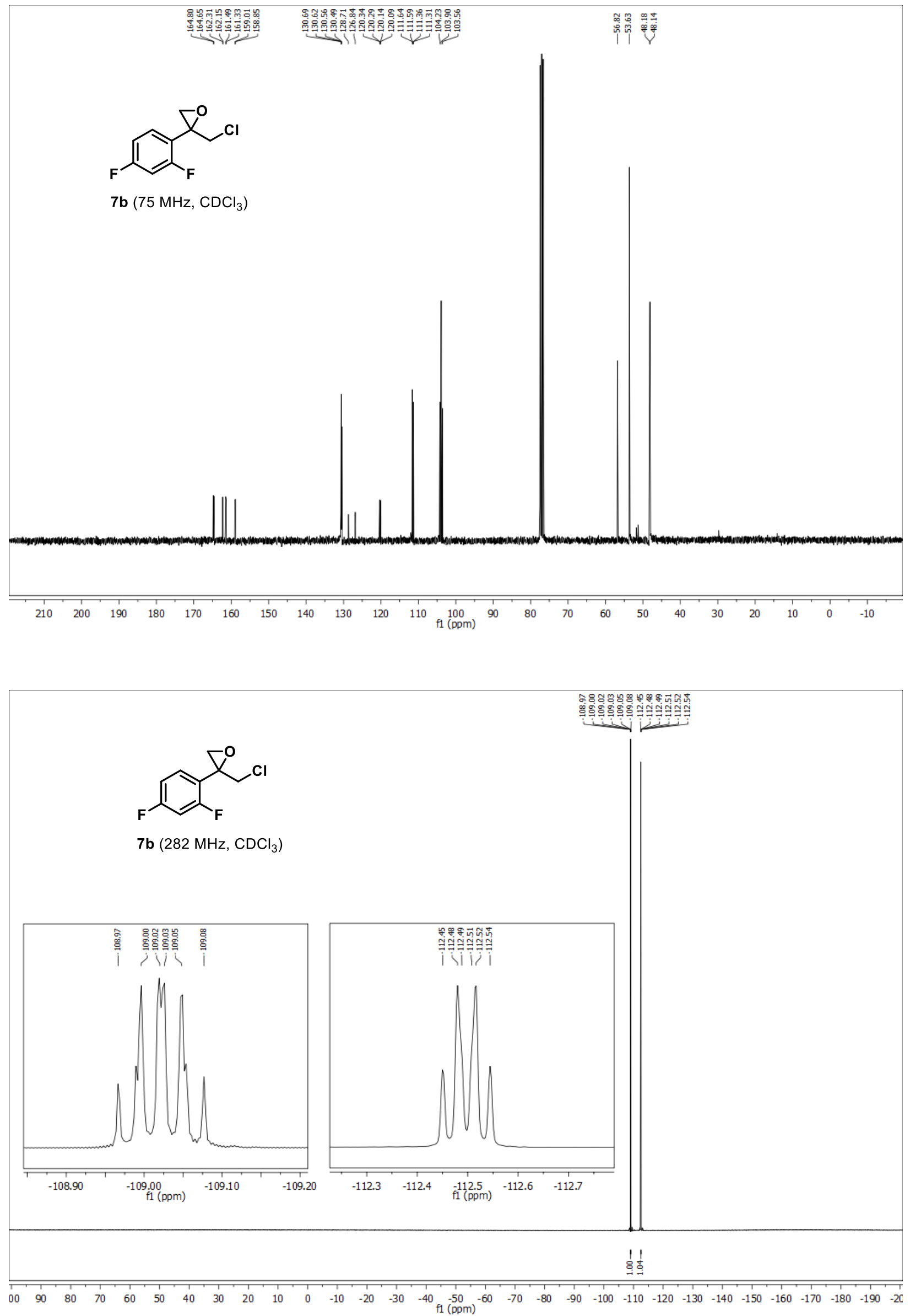


\section{Supplementary References}

S1. Commenge, J.-M.; Falk, L. Chem. Eng. Process. Process Intensif. 2011, 50, 979-990.

S2. Degennaro, L.; Fanelli, F.; Giovine, A.; Luisi, R. Adv. Synth. Catal. 2014, 357, 21-27.

S3. Bentley, P. A.; Mei, Y.; Du, J. Tetrahedron Lett. 2008, 49, 1425-1427.

S4. Nishimura, R. H. V.; Toledo, F. T.; Lopes, J. L. C.; Clososki, G. C. Tetrahedron Lett. 2013, 54, 287290.

S5. Egami, H.; Yoneda, T.; Uku, M.; Ide, T.; Kawato, Y.; Hamashima, Y. J. Org. Chem. 2016, 81, 40204030.

S6. Nishimura, R. H. V.; Murie, V. E.; Soldi, R. A.; Clososki, G. C. Synthesis (Stuttg). 2015, 47, 14551460.

S7. Talwar, D.; Wu, X.; Saidi, O.; Salguero, N. P.; Xiao, J. Chem. Eur. J. 2014, 20, 12835-12842.

S8. Haak, R. M.; Berthiol, F.; Jerphagnon, T.; Gayet, A. J. A.; Tarabiono, C.; Postema, C. P.; Ritleng, V.;

Pfeffer, M.; Janssen, D. B.; Minnaard, A. J. et al., J. Am. Chem. Soc. 2008, 130, 13508-13509.

S9. Tanyeli, C.; Demir, A. S.; Akhmedov, I. M.; Özgül, E.; Kandemir, C. G. Synth. Commun. 1996, 26, 2967-2980.

S10. Korwar, S.; Amir, S.; Tosso, P. N.; Desai, B. K.; Kong, C. J.; Fadnis, S.; Telang, N. S.; Ahmad, S.;

Roper, T. D.; Gupton, B. F. European J. Org. Chem. 2017, 2017, 6495-6498.

S11. Trost, B. M.; Tracy, J. S. Chem. A Eur. J. 2015, 21, 15108-15112.

S12. Piccinini, A.; Kavanagh, S. A.; Connon, P. B.; Connon, S. J. Org. Lett. 2010, 12, 608-611.

S13. Nodzewska, A.; Watkinson, M. Chem. Commun. 2018, 54, 1461-1464.

S14. Polidano, K.; Reed-Berendt, B. G.; Basset, A.; Watson, A. J. A.; Williams, J. M. J.; Morrill, L. C.

Org. Lett. 2017, 19, 6716-6719.

S15. Wang, Z.; Xue, F.; Hayashi, T. Angew. Chem. Int. Ed. 2019, 58, 11054-11057.

S16. He, G.; Zhang, S. Y.; Nack, W. A.; Pearson, R.; Rabb-Lynch, J.; Chen, G. Org. Lett. 2014, 16, 6488-6491.

S17. Von Keutz, T.; Cantillo, D.; Kappe, C. O. Org. Lett. 2019, 21, 10094-10098.

S18. Guss, C. O. J. Am. Chem. Soc. 1953, 75, 3177-3179.

S19. Pedragosa-Moreau, S.; Morisseau, C.; Zylber, J.; Archelas, A.; Baratti, J.; Furstoss, R. J. Org. Chem. 1996, 61, 7402-7407.

S20. Monfort, N.; Archelas, A.; Furstoss, R. Tetrahedron 2004, 60, 601-605. 